In cooperation with the Michigan Department of Natural Resources and Environment

\title{
Predicting Lake Trophic State by Relating Secchi-Disk Transparency Measurements to Landsat-Satellite Imagery for Michigan Inland Lakes, 2003-05 and 2007-08
}

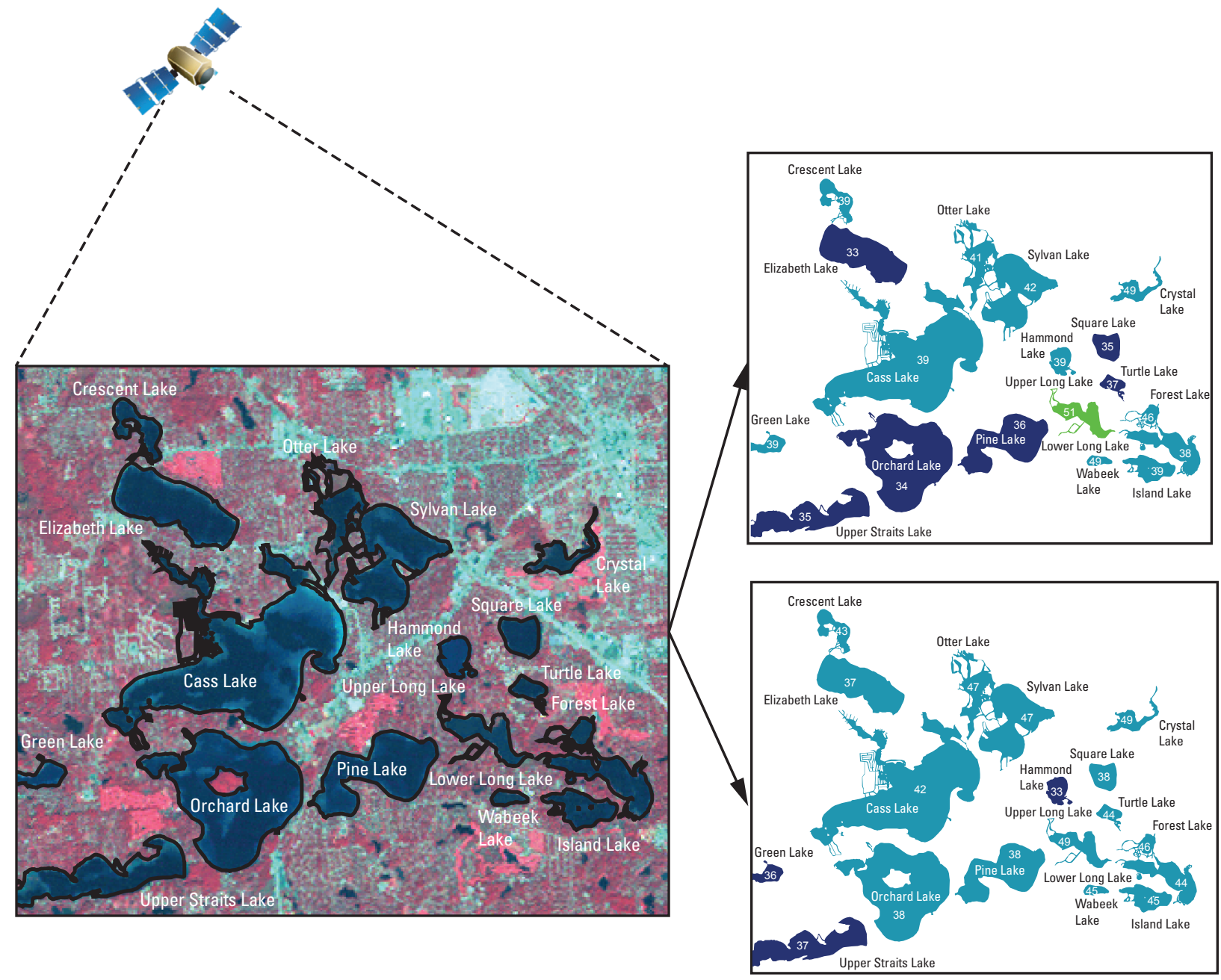

Scientific Investigations Report 2011-5007 



\section{Predicting Lake Trophic State by Relating Secchi-Disk Transparency Measurements to Landsat-Satellite Imagery for Michigan Inland Lakes, 2003-05 and 2007-08}

By L.M. Fuller, R.S. Jodoin, and R.J. Minnerick

In cooperation with the Michigan Department of Natural Resources

and Environment

Scientific Investigations Report 2011-5007 


\title{
U.S. Department of the Interior \\ KEN SALAZAR, Secretary \\ U.S. Geological Survey \\ Marcia K. McNutt, Director
}

\author{
U.S. Geological Survey, Reston, Virginia: 2011
}

For more information on the USGS - the Federal source for science about the Earth, its natural and living resources, natural hazards, and the environment, visit http://www.usgs.gov or call 1-888-ASK-USGS.

For an overview of USGS information products, including maps, imagery, and publications, visit http://www.usgs.gov/pubprod

To order this and other USGS information products, visit http://store.usgs.gov

Any use of trade, product, or firm names is for descriptive purposes only and does not imply endorsement by the U.S. Government.

Although this report is in the public domain, permission must be secured from the individual copyright owners to reproduce any copyrighted materials contained within this report.

Suggested citation:

Fuller, L.M., Jodoin, R.S., and Minnerick, R.J., 2011, Predicting lake trophic state by relating Secchi-disk transparency measurements to Landsat-satellite imagery for Michigan inland lakes, 2003-05 and 2007-08: U.S. Geological Survey Scientific Investigations Report 2011-5007, 36 p. 


\section{Acknowledgments}

Mr. Ralph Bednarz of the Michigan Department of Natural Resources and Environment and the volunteers of the Cooperative Lake Monitoring Program (CLMP) were invaluable in providing much of the field data used in the project. Leif Olmanson of the Remote Sensing and Geospatial Analysis Laboratory, Department of Forest Resources, University of Minnesota provided the Gethist program for use in analyzing Michigan inland lakes.

U.S. Geological Survey (USGS) field technicians provided measurements for the Upper Peninsula of Michigan to supplement the measurements from volunteers of the CLMP. The following USGS Michigan Water Science Center employees were involved in the collection of data for this study: D. Burdett, J.M. Ellis, S.B. Horton, J. Knudsen, D.G. Wydra, and J.A. Wilkinson. 



\section{Contents}

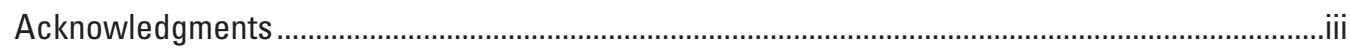

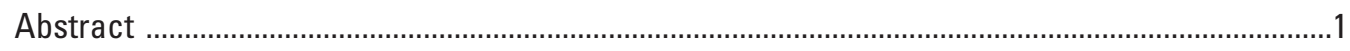

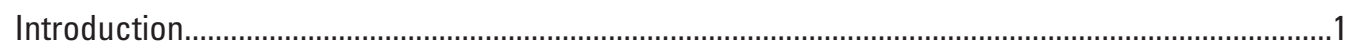

Previous Studies Relating Secchi-Disk Transparency to Inland Lakes..................................2

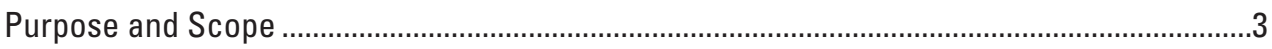

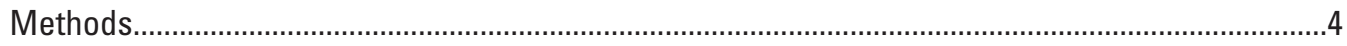

Landsat-Satellite Imagery Acquisition and Processing .........................................................

Water-Only Image ...................................................................................................

Field Data Collection and Processing .......................................................................

Relating Field Data to Landsat-Satellite Imagery ....................................................................

AOI Method To Select Open-Water Areas .....................................................................

Gethist Method To Select Open-Water Areas ......................................................................7

Trophic State Index Calculation for SDT .....................................................................

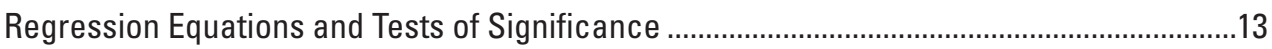

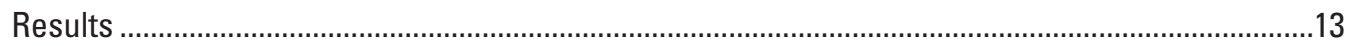

Landsat-Satellite Imagery Data-Processing Improvements ..................................................13

Comparison of the AOI Lake-Average Method and the Gethist Method................................14

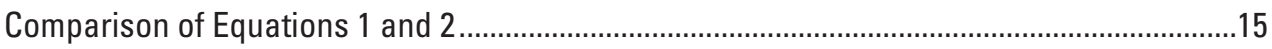

Summary and Conclusions .......................................................................................................

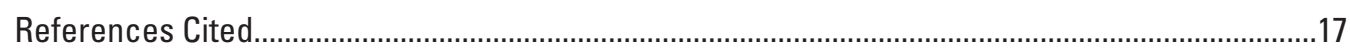

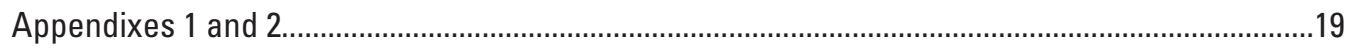

1. Results and computations by Landsat-satellite path for Michigan inland lakes, 2003-05, of measured and predicted Secchi-disk transparency and Trophic State Index values for the area of interest, area of interest lakeaverage method, and the Gethist method.

2. Results and computations by Landsat-satellite path for Michigan inland lakes, 2007-08, of measured and predicted Secchi-disk transparency and Trophic State Index values for the area of interest, area of interest lakeaverage method, and the Gethist method..

\section{Figures}

1. Maps showing Landsat coverage for statewide predicted Trophic State Index and Secchi-disk transparency for 2003-05 and 2007-08

2. Landsat path 20 satellite image for September 22, 2004, in Oakland County, Michigan, for $\boldsymbol{A}$, before satellite-data processing and $\boldsymbol{B}$, after satellitedata processing

3. Photograph of example of Secchi disk used to measure water clarity in lakes................6 
4. Scatterplots for $\boldsymbol{A}, 2003-05$ and $\boldsymbol{B}, 2007-08$ of $A$, Michigan measured

Trophic State Index (TSI) values and Secchi-disk transparency (SDT) values, in feet, to predicted TSI and SDT values using equation 1 for both the area of interest (AOI) lake-average method and the Gethist method; $B$, measured TSI values and SDT values, in feet, to predicted TSI and SDT values using equation 2 for both the AOI lake-average method and the Gethist method; and $C$, predicted TSI and SDT values using equation 1 to predicted TSI and SDT values using equation 2 .

5. Scatterplots for $\boldsymbol{A}, 2003-05$ and $\boldsymbol{B}, 2007-08$ of Michigan inland lakes greater than 20 acres with available open-water areas for statewide predicted Trophic State Index values and Secchi-disk transparency, in feet, using the Gethist method for equations 1 and 2.

6. Maps showing Landsat path 20, in Oakland County, Michigan, for

A, Predicted Trophic State Index values for Michigan inland lakes 2003-05 and

B, Predicted Trophic State Index values for Michigan inland lakes 2007-08 14

\section{Tables}

1. Lake Trophic State Index and classification ranges using Trophic State Index values, Secchi-disk transparency, chlorophyll-a, and total phosphorus for Michigan inland lakes, 2003-05 and 2007-08.

2. Landsat 5 Thematic Mapper and Landsat 7 Enhanced Thematic Mapper Plus bands and corresponding wavelengths

3. Landsat-image and calibration-model data for Michigan inland lakes, 2003-05 and 2007-08

4. Results comparing methods using equations 1 and 2 for 2003-05 and 2007-08 in percent for measured Secchi-disk transparency values within 2, 5, and 10 feet of the predicted Secchi-disk transparency; and percent for measured Trophic State Index values within 2, 5, and 10 units of the predicted Trophic State Index values for Michigan inland lakes.

5. Predicted Trophic State Index and Secchi-disk transparency results for Fisher's Transformation Significance Tests for Michigan inland lakes, 2003-05 and 2007-08

6. Comparison of Predicted Trophic State Index and Secchi-disk transparency results for equations 1 and 2 using Fisher's Transformation Significance Tests for Michigan inland lakes, 2003-05 and 2007-08.

7. Count and percent of measured and statewide predicted Trophic State classes for Michigan inland lakes, 2003-05 and 2007-08. 


\section{Conversion Factors}

\begin{tabular}{lcl}
\hline & Multiply & \multicolumn{1}{c}{ To obtain } \\
\hline inch (in.) & Length & \\
foot $(\mathrm{ft})$ & 2.54 & centimeter $(\mathrm{cm})$ \\
meter $(\mathrm{m})$ & 0.3048 & meter $(\mathrm{m})$ \\
\hline & 3.281 & foot $(\mathrm{ft})$ \\
\hline acre & Area & \\
square meter $\left(\mathrm{m}^{2}\right)$ & 4,047 & square meter $\left(\mathrm{m}^{2}\right)$ \\
acre & 0.0002471 & acre \\
\hline & 0.004047 & square kilometer $\left(\mathrm{km}{ }^{2}\right)$ \\
\hline micrograms per liter $(\mu \mathrm{g} / \mathrm{L})$ & Concentration & \\
\hline
\end{tabular}

Vertical coordinate information is referenced to the North American Datum of 1983 (NAD 83).

Abbreviations used in this report

$\mathrm{AOI}$ area of interest

Chl-a chlorophyll $a$

CLMP Cooperative Lakes Monitoring Program

GPS global positioning system

LWQA Lake Water Quality Assessment

MDNRE Michigan Department of Natural Resources and Environment

$\mathrm{R}^{2}$ coefficient of determination

SDT Secchi-disk transparency

TM Thematic Mapper

TP total phosphorus

TSI Trophic State Index

USGS U.S. Geological Survey 



\title{
Predicting Lake Trophic State by Relating Secchi-Disk Transparency Measurements to Landsat-Satellite Imagery for Michigan Inland Lakes, 2003-05 and 2007-08
}

\author{
By L.M. Fuller, R.S. Jodoin, and R.J. Minnerick
}

\begin{abstract}
Inland lakes are an important economic and environmental resource for Michigan. The U.S. Geological Survey and the Michigan Department of Natural Resources and Environment have been cooperatively monitoring the quality of selected lakes in Michigan through the Lake Water Quality Assessment program. Sampling for this program began in 2001; by 2010, 730 of Michigan's 11,000 inland lakes are expected to have been sampled once. Volunteers coordinated by the Michigan Department of Natural Resources and Environment began sampling lakes in 1974 and continue to sample (in 2010) approximately 250 inland lakes each year through the Michigan Cooperative Lakes Monitoring Program. Despite these sampling efforts, it still is impossible to physically collect measurements for all Michigan inland lakes; however, Landsat-satellite imagery has been used successfully in Minnesota, Wisconsin, Michigan, and elsewhere to predict the trophic state of unsampled inland lakes greater than 20 acres by producing regression equations relating in-place Secchi-disk measurements to Landsat bands. This study tested three alternatives to methods previously used in Michigan to improve results for predicted statewide Trophic State Index (TSI) computed from Secchi-disk transparency (TSI (SDT)). The alternative methods were used on 14 Landsat-satellite scenes with statewide TSI (SDT) for two time periods (200305 and 2007-08). Specifically, the methods were (1) satellitedata processing techniques to remove areas affected by clouds, cloud shadows, haze, shoreline, and dense vegetation for inland lakes greater than 20 acres in Michigan; (2) comparison of the previous method for producing a single open-water predicted TSI (SDT) value (which was based on an area of interest (AOI) and lake-average approach) to an alternative Gethist method for identifying open-water areas in inland lakes (which follows the initial satellite-data processing and targets the darkest pixels, representing the deepest water, before regression equations are created); and (3) checking to see whether the predicted TSI (SDT) values compared well between two regression equations, one previously used in Michigan and an alternative equation from the hydrologic literature.
\end{abstract}

\begin{abstract}
The combination of improved satellite-data processing techniques and the Gethist method to identify open-water areas in inland lakes during 2003-05 and 2007-08 provided a stronger relation and statistical significance between predicted TSI (SDT) and measured TSI than did the AOI lake-average method; differences in results for the two methods were significant at the 99-percent confidence level. With regard to the comparison of the regression equations, there were no statistically significant differences at the 95 -percent confidence level between results from the two equations. The previously used equation, in combination with the Gethist method, yielded coefficient of determination $\left(\mathrm{R}^{2}\right)$ values of 0.71 and 0.77 for the periods $2003-05$ and 2007-08, respectively. The alternative equation, in combination with the Gethist method, yielded $\mathrm{R}^{2}$ values of 0.74 and 0.75 for $2003-05$ and 2007-08, respectively. Predicted TSI (SDT) and measured TSI (SDT) values for lakes used in the regression equations compared well, with $\mathrm{R}^{2}$ values of 0.95 and 0.96 for predicted TSI (SDT) for 2003-05 and 2007-08, respectively. The $\mathrm{R}^{2}$ values for statewide predicted TSI (SDT) for all inland lakes with available open-water areas for 2003-05 and 2007-08 were 0.91 and 0.93 , respectively. Although the two equations predicted similar trophic-state classes, the alternative equation is planned to be used for future prediction of TSI (SDT) values for Michigan inland lakes, to promote consistency in comparing predicted values between States and for potential use in trend analysis.
\end{abstract}

\section{Introduction}

The State of Michigan has more than 11,000 inland lakes; approximately 4,000 of these lakes are greater than 20 acres in size. The public has access to launches or beaches at about 1,300 lakes in Michigan. Recreational, property, and ecological values all are closely related to the quality of water in these inland lakes (Krysel and others, 2003). Tourism in Michigan, much of which involves recreation at inland lakes, accounts for nearly $\$ 12$ billion of economic activity each year 
(Stynes, 2002). Thus, inland lakes are important economic and ecological resources to Michigan.

The U.S. Geological Survey (USGS) and the Michigan Department of Natural Resources and Environment (MDNRE) have been cooperatively monitoring the quality of inland lakes in Michigan through the Lake Water Quality Assessment (LWQA) monitoring program funded by the Clean Michigan Initiative. Through this program, the USGS has been sampling public-access lakes over 25 acres in size in both the spring and late summer. Sampling began in 2001; by 2010, 730 such lakes are expected to have been sampled. In addition, each year the MDNRE plans to provide data from their Cooperative Lakes Monitoring Program (CLMP), which is a volunteer network monitoring approximately 250 lakes weekly to monthly. Data from those two sampling networks are being used to characterize baseline water quality and compute trophic state of monitored inland lakes.

Measured water-quality characteristics of inland lakes are critical factors in determining the lakes' recreational use, habitat and species diversity, and economic return from the tourism industry. The USGS and the MDNRE monitor many inland lakes, but it is not economically feasible to monitor the quality of all 11,000 inland lakes in Michigan by use of conventional sampling techniques. Knowledge of the biological productivity of unsampled inland lakes is needed to assist resource managers in their efforts to protect and manage the quality in all of Michigan's inland lakes.

Landsat-satellite imagery has been used successfully in Minnesota (Olmanson and others, 2001; Kloiber and others, 2002), Wisconsin (Chipman and others, 2004; Peckham and Lillesand, 2006), and elsewhere (Baban, 1993; Dekker and Peters, 1993; Mayo and others, 1995; Giardino and others, 2001) to estimate Trophic State Index (TSI) Secchi-disk transparency (SDT) for unsampled inland lakes. During previous studies in Michigan (Nelson and others, 2003; Wiangwang, 2002), researchers attempted to use existing models for relating Landsat-satellite imagery to SDT; however, they were unable to obtain as high a coefficient of determination $\left(\mathrm{R}^{2}\right.$; an indicator of the strength of a statistical relation) as did researchers in previous studies in Minnesota and Wisconsin. Fuller and others (2004) estimated TSI (SDT) for Lower Michigan, using an alternative regression equation to that used by Olmanson and others (2001), with slightly higher $\mathrm{R}^{2}$ values. Results from a study by Fuller and Minnerick (2007) documented a good fit between measured and statewide predicted TSI (SDT). Knowledge of improved satellite-data processing techniques, an alternative Gethist method to identify the open-water areas in satellite data, and two available regression equations used to predict trophic characteristics from Landsat-satellite imagery prompted a revisit of methods from Fuller and others (2004) to examine which methods would produce predictions more reflective of measured values for two sets of data from 2003-05 and 2007-08. Refining methods would improve and increase the knowledge about Michigan's inland lakes.

\section{Previous Studies Relating Secchi-Disk Transparency to Inland Lakes}

Carlson (1977) proposed to quantify the trophic state by its TSI, which can be classified into basic classes of oligotrophic, mesotrophic, eutrophic, and hypereutrophic. Carlson's TSI model was developed for use with lakes that have few rooted aquatic plants and little non-algal turbidity (U.S. Environmental Protection Agency, 2007). The natural progression of a lake from oligotrophic to eutrophic can be computed from measures of total phosphorus (TP), Secchi-disk transparency (SDT), and chlorophyll $a(\mathrm{Chl}-a)$. Table 1 shows the range of TSI values and how each measure is classified into oligotrophic, mesotrophic, eutrophic, and hypereutrophic.

The formulas for calculating TSI values are

$$
\begin{aligned}
& T S I=60-14.41 \ln (\mathrm{SDT} \text { feet } * 0.3048) \\
& T S I=9.81 \ln \text { Chl }-a(\text { micrograms per liter }(\mu \mathrm{g} / \mathrm{L}))+30.6 \\
& T S I=14.41 \ln \mathrm{TP}(\mu \mathrm{g} / \mathrm{L})+4.15
\end{aligned}
$$

SDT is a commonly used, low-cost technique that measures water clarity; specifically, a black and white disk is lowered into the lake until it no longer can be seen. Water clarity is related to the quantity of phytoplankton in the water, although non-algal turbidity and tannic acids also can reduce water clarity. Chl- $a$ measurements correlate with the concentration of phytoplankton within a given volume of lake water and are not affected by sediment or acids in the water. Typically, computing TSI values for a single lake using all three formulas should yield similar results. Increasing the concentration of phosphorus generally results in increased concentration of phytoplankton, which results in reduced water clarity. Yet at specific times of the year, or on specific lakes, results from the three formulas may not be congruous because of phosphorus-nutrient uptake by macrophytes. Therefore, substantial

Table 1. Lake Trophic State Index and classification ranges using Trophic State Index values, Secchi-disk transparency, chlorophyll-a, and total phosphorus for Michigan inland lakes, 2003-05 and 2007-08.

[TSI, Trophic State Index; SDT, Secchi-disk transparency; ft, feet; Chl- $a$; chlorophyll- $a$; $\mu \mathrm{g} / \mathrm{L}$, micrograms per liter; TP, ttal phosphorus; $<$, less than; >, greater than; data from Warbach (1990) and modified by the State of Michigan to account for regional characteristics]

\begin{tabular}{lcccc}
\hline $\begin{array}{c}\text { Lake trophic } \\
\text { condition }\end{array}$ & Carlson TSI & $\begin{array}{c}\text { SDT } \\
(\mathbf{f t})\end{array}$ & $\begin{array}{c}\text { Chl-a } \\
(\boldsymbol{\mu} \mathbf{g} / \mathbf{l})\end{array}$ & $\begin{array}{c}\text { TP } \\
(\boldsymbol{\mu g} / \mathrm{L})\end{array}$ \\
\hline Oligotrophic & $<38$ & $>15$ & $<2.2$ & $<10$ \\
Mesotrophic & $38-48$ & $7.5-15$ & $2.2-6$ & $10-20$ \\
Eutrophic & $49-61$ & $3-7.4$ & $6.1-22$ & $20.1-50$ \\
Hypereutrophic & $>61$ & $<3$ & $>22$ & $>50$ \\
\hline
\end{tabular}


amounts of macrophytes in a lake may alter the relation of the three TSI values.

Of the three measures, SDT and concentration of Chl- $a$ are quantifiable using remote-sensing techniques (Mayo and others, 1995; Zilioli and Brivio, 1997; Kloiber and others, 2000; Giardino and others, 2001; and Kloiber and others, 2002), though Kutser and others (2006) cautioned that Landsat-satellite imagery does not have adequate narrow spectral bands to distinguish the unique spectral signature of Chl- $a$, and regression equations actually may be predicting turbidity as it correlates to Chl- $a$.

A variety of equations relating SDT to Landsat-satellite imagery have been tested in different settings and with different sensors. Olmanson and others (2001) and Kloiber and others (2002) used the following equation for Minnesota lakes along with data from Landsat 5 Thematic Mapper (TM) and Landsat 7 Enhanced Thematic Mapper plus (ETM+) satellites:

$$
\ln (\mathrm{SDT})=a(\text { band } 1 / \text { band } 3)+b(\text { band } 1)+c
$$

Fuller and others (2004), who also used Landsat satellite 5 $\mathrm{TM}$, found an alternative equation for Michigan lakes that improved the relation, but the relation was not statistically significant at the 95-percent confidence level:

$$
\ln (\mathrm{SDT})=a(\text { band } 1)+b(\text { band } 2)+c(\text { band } 3)+d
$$

The variables $a, b$, and $c$ are empirically derived coefficients from the regression equation. Table 2 shows Landsat (TM) and Landsat $(\mathrm{ETM}+)$ bands and corresponding wavelength ranges.

In Fuller and others (2004), methods similar to those published in Olmanson and others (2001) were followed to produce predicted TSI (SDT) for Michigan inland lakes for the Lower Peninsula of Michigan. A statewide predicted TSI for 2003-06 from Fuller and Minnerick (2007) compared well to measurements, but the accuracy declined slightly owing to the method used to produce a predicted TSI (SDT) value reflective of the open-water area for each lake. Because we do not know the deep-basin location for all inland lakes in Michigan, the regression equation derived from using an Area of Interest
(AOI) around the measurements was applied to all areas after satellite-data processing within each inland lake. All 30-m pixels within the area for each inland lake that remained after satellite-data processing were averaged to produce a single open-water predicted TSI value for each inland lake.

Minnesota and Wisconsin have used a Gethist program to reduce the areas remaining after satellite-data processing to identify the darkest pixels, which were then used to both produce regression equations and produce a single predicted TSI (SDT) value for each inland lake more representative of the open-water area. By use of this additional step, Minnesota and Wisconsin obtained statewide predicted TSI (SDT) for 20 and 30 years, respectively, and analyzed potential trends (Olmanson and others, 2008 Peckham and Lillesand, 2006). With improved methods, Michigan also could follow suit to produce predicted TSI (SDT) to monitor potential trends for inland lakes. Temporal statewide predictions would be useful for lake managers to monitor potential changes in Michigan inland lakes.

\section{Purpose and Scope}

This report was written to (1) document alternative methods for processing Landsat-satellite imagery that would remove areas affected by clouds, cloud shadows, haze, shoreline, and dense vegetation for inland lakes greater than 20 acres in Michigan; (2) compare the previous method of producing a single open water predicted TSI (SDT) value using an area of interest (AOI) and lake-average method to an alternative Gethist method; and (3) ascertain if the predicted TSI (SDT) and SDT values compared well between the regression equation in Fuller and others (2004) to the regression equation in Olmanson and others (2001) for statewide predictions for two time periods: $2003-05$ and $2007-08$. The methods used to produce the statewide predictions will be described, the field data-collection methods will be included only by reference.

Table 2. Landsat 5 Thematic Mapper and Landsat 7 Enhanced Thematic Mapper Plus bands and corresponding wavelengths.

\begin{tabular}{|c|c|c|c|c|c|c|c|c|}
\hline Landsat satellite & \multicolumn{3}{|c|}{ Visible spectrum } & \multicolumn{2}{|c|}{ Near-infrared } & $\begin{array}{l}\text { Thermal } \\
\text { Band } 6\end{array}$ & $\frac{\text { Mid-infrared }}{\text { Band } 7}$ & $\frac{\text { Panchromatic }}{\text { Band } 8}$ \\
\hline Landsat 5 Thematic Mapper & $\begin{array}{c}0.45-0.52 \\
\mu \mathrm{m}\end{array}$ & $\begin{array}{c}0.52-0.60 \\
\mu \mathrm{m}\end{array}$ & $\begin{array}{c}0.63-0.69 \\
\mu \mathrm{m}\end{array}$ & $\begin{array}{c}0.76-0.90 \\
\mu \mathrm{m}\end{array}$ & $\begin{array}{c}1.55-1.75 \\
\mu \mathrm{m}\end{array}$ & $\begin{array}{c}10.40-12.50 \\
\mu \mathrm{m}\end{array}$ & $\begin{array}{c}2.08-2.35 \\
\mu \mathrm{m}\end{array}$ & $\begin{array}{c}\text { Not } \\
\text { available }\end{array}$ \\
\hline $\begin{array}{l}\text { Landsat } 7 \text { Enhanced Thematic } \\
\text { Mapper plus }\end{array}$ & $\begin{array}{c}0.45-0.52 \\
\mu \mathrm{m}\end{array}$ & $\begin{array}{l}0.52-0.60 \\
\mu \mathrm{m}\end{array}$ & $\begin{array}{c}0.63-0.69 \\
\mu \mathrm{m}\end{array}$ & $\begin{array}{c}0.77-0.90 \\
\mu \mathrm{m}\end{array}$ & $\begin{array}{c}1.55-1.75 \\
\mu \mathrm{m}\end{array}$ & $\begin{array}{c}10.40-12.50 \\
\mu \mathrm{m}\end{array}$ & $\begin{array}{c}2.08-2.35 \\
\mu \mathrm{m}\end{array}$ & $\begin{array}{l}0.52-0.90 \\
\mu \mathrm{m}\end{array}$ \\
\hline
\end{tabular}

[ $\mu \mathrm{m}$, micrometers] 
Predicting Lake Trophic State for Michigan Inland Lakes, 2003-05 and 2007-08

\section{Methods}

Relating remote-sensing Landsat-satellite imagery to Secchi-disk measurements involves several steps, which can be grouped into three categories. First, relatively cloud-free Landsat-satellite imagery is chosen during the late-summer period and processed to remove areas affected by clouds, cloud shadows, haze, shoreline, and dense vegetation for inland lakes greater than 20 acres in Michigan. Second, field data corresponding to the Landsat-satellite imagery are obtained. Third, the field data within plus or minus 7 days of the Landsat-satellite imagery acquisition date are related to produce a regression model specific to each date of Landsatsatellite imagery. The end results are predicted TSI (SDT) values for desirable open-water areas for inland lakes greater than 20 acres within the Landsat-satellite scenes.

\section{Landsat-Satellite Imagery Acquisition and Processing}

Seven paths of Landsat 5 Thematic Mapper (TM) satellite data (14 satellite scenes) were processed for 2003-05 and 2007-08. The 14 Landsat-satellite scenes encompassing Michigan are referenced by both a path number and a row number (fig. 1). The Landsat-satellite scenes were selected for one date from a 3-month period (July-September) with the least amount of cloud cover and haze (preferably less than 10 percent cloud cover). These months have been shown to produce the most accurate predictive models, because the lakes are at their maximum biological productivity (Kloiber and others, 2000).

Only one date per Landsat-satellite scene is included each year. Although temporal coverage during the season would be interesting, Landsat has a 16-day repeat cycle only allowing 5 to 6 dates available per scene during the 3-month period from mid July to September. Usually only one date per scene is available with less than 10 percent cloud cover, the percentage necessary to produce reliable predictions. For the 2003-05 dataset, 3 years of data were used to complete the statewide predictions. In 2007, a sampling plan was implemented to produce a statewide predicted TSI (SDT) every other year. The sampling plan was to produce paths 20 to 23 with year 1 Landsat-satellite imagery and paths 24 and 25 with year 2 Landsat-satellite imagery; Landsat-satellite imagery for 2007-08 is shown on figure 1 .

The images arrived in 1P format, which means they were systematically corrected (geometric and radiometric corrections) and provided an "end result [that] was a geometrically rectified product free from distortions related to the sensor (for example, jitter, view angle effects), satellite (for example, attitude deviations from nominal), and Earth (for example, rotation, curvature)" (National Aeronautics Space Administration, 2003), with ground-control points to improve spatial accuracy. The format chosen helped ensure that the image cells would correspond to the data-collection points as closely as possible.
Landsat-imagery processing was completed with ERDAS IMAGINE 9.3 and 10.0 software. The Landsat-satellite scenes were delivered in the Universal Transverse Mercator projection system by using the World Geodetic System 84 North American Datum zone 16 or 17, depending on the scene. Each scene was reprojected into Michigan Georef by using an Oblique Mercator projection, NAD83 datum, in meters. The Michigan Georef projection was used because it ensures one zone for all of Michigan, and it is used by most Federal, State, and local agencies in Michigan. When each image was compared with the Michigan transportation framework developed by the Michigan Center for Geographic Information, it was found to be accurate to within 1 to 2 cells or about 30 to $60 \mathrm{~m}$. This accuracy was acceptable to place the measurements for each inland lake into the deep open-water area.

Landsat satellites record values for each $30-\times 30-\mathrm{m}$ $\left(900-\mathrm{m}^{2}\right)$ area (cell), in wavelength ranges (bands). Bands 1, 2, and 3 (visible spectrum of blue, green, and red, respectively) are used in this project. All bands have cell sizes of $30 \mathrm{~m}$, so $900 \mathrm{~m}^{2}$ of Earth are represented in one cell by one value for each band. TSI (SDT) predictions are made for lakes greater than 20 acres (approximately $81,000 \mathrm{~m}^{2}$ ) to allow an adequate number of cells in the open-water area of the inland lakes to produce an accurate predictive model.

\section{Water-Only Image}

The water-only images are created to reduce file size and target analysis on the open-water area for inland lakes greater than 20 acres. Whereas Olmanson and others (2001) used an unsupervised classification to obtain open-water areas, we used a mask function was used to select pixels from the Landsat-satellite imagery that corresponded to a Michigan inland lakes polygon shapefile greater than 20 acres (from Breck, 2004). When the Landsat-satellite imagery was masked to match the inland lakes shapefile, some $30-\mathrm{m}$ pixels were selected as water (inside the lakes-polygon shapefile), including vegetated areas of the shoreline, islands, or shallow water with vegetation.

A Normalized Difference Vegetation Index, which responds to the amount of green biomass (Jensen, 2007), was applied to remove the vegetated pixels within the inland lakespolygon shapefile that corresponded to shoreline, islands, and shallow vegetated water. The resulting pixels had a negative value; thus, greenness presence was removed. An unsupervised classification was performed on the remaining pixels using 10 classes, 50 iterations, and a 0.99-confidence level. If necessary, the unsupervised classification was repeated. This step facilitated masking out more areas with clouds, shallow areas, or shoreline.

The final check was to input the remaining areas after the satellite-data processing into ArcMap 9.3 and display with a band 1,6,6 combination (mapping the blue band onto band 1, and bands 6 onto the green and red bands, respectively) to identify if any lakes were affected by haze or cloud shadows (a technique suggested by Olmanson and others, 2008). Lakes 

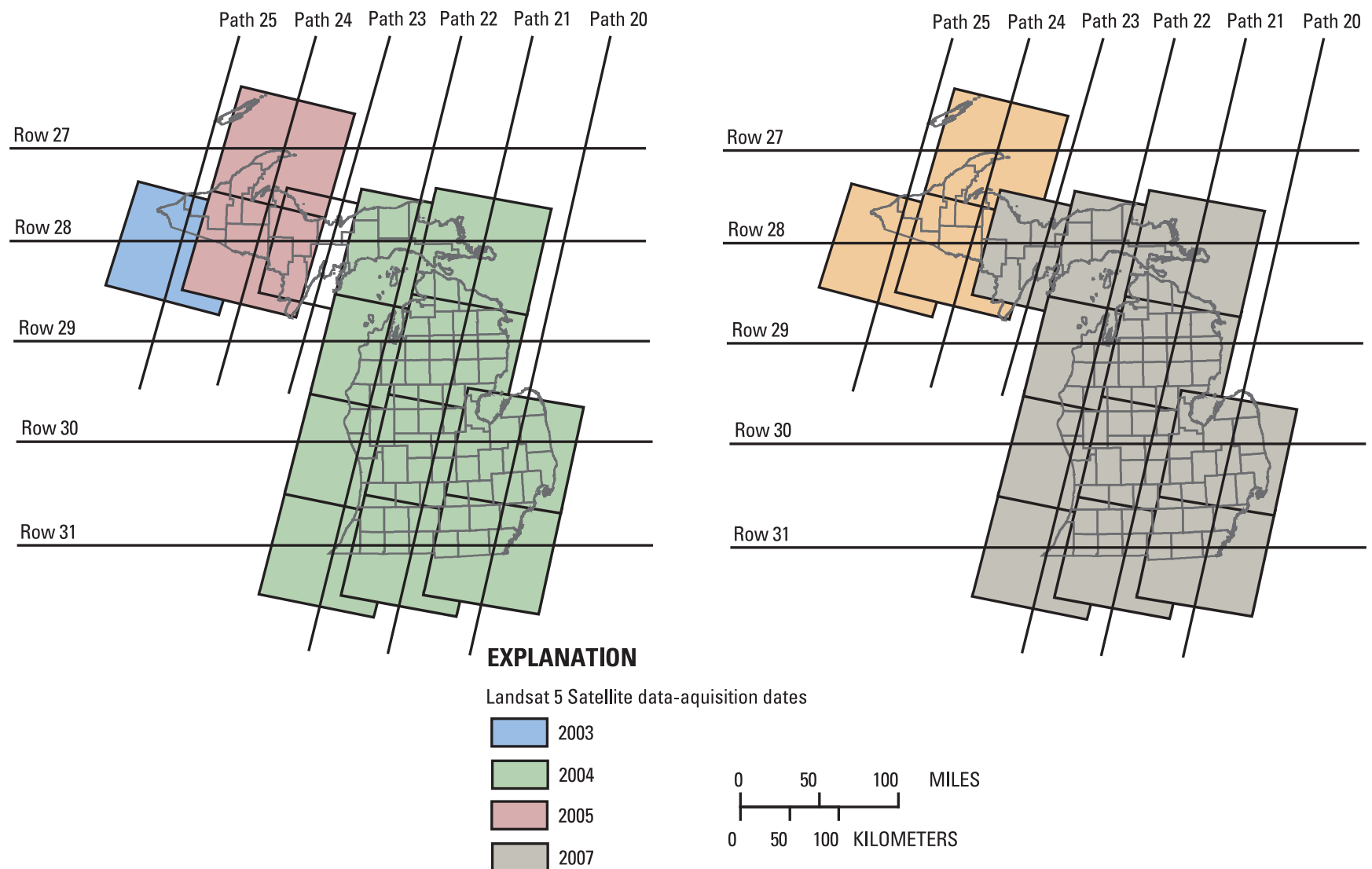

Figure 1. Landsat coverage for statewide predicted Trophic State Index and Secchi-disk transparency for 2003-05 and 2007-08.

were removed from the calculation if they were affected by haze, and affected areas were removed from large lakes that still had good representation in the open-water areas. See figure 2 for before-and-after Landsat-imagery processing to obtain open-water areas for use in regression equations for a portion of Oakland County, Michigan, inland lakes.

\section{Field Data Collection and Processing}

A Secchi disk is a common tool used to measure the overall clarity of water. The Secchi disk is an 8-in.-diameter circular disk painted black and white in alternating quadrants (fig. 3). The disk is lowered into the water, and the depth at which the disk is no longer visible is known as the SDT. Measurements of SDT were obtained from volunteers in the MDNRE CLMP who routinely measure SDT for various lakes in Michigan. SDT measurements done by volunteers have been studied and proven to be comparable with measurements done by professionals (Canfield and others, 2002; Obrecht and others, 1998). USGS field technicians collected samples in the Northern Lower Peninsula and the Upper Peninsula of Michigan immediately after Landsat-satellite scenes with low cloud cover to supplement measurements made by CLMP volunteers.
Shapefiles were created with measurements in the Michigan Georef projection that corresponded to a window of 7 days before or after satellite-acquisition dates, and this approach produced accurate predictive models. This window produced the best results in predictive SDT models (Kloiber and others, 2002). The number of measurements per path varied but a minimum of 20 measurements per Landsat-satellite scene in a path was desirable. Measurements were made at the deepest point in the lake so that reflectance from the bottom of the lake did not affect the measurements. The locations of the measurements used were noted during sampling, either by using a global positioning system (GPS) unit to record latitude and longitude coordinates or by clearly marking locations on a map during sampling and digitizing later to determine their coordinates.

All SDT measurements were reviewed; some were omitted owing to clouds, cloud shadows, or haze covering the open-water areas of the inland lake. Clouds and cloud shadows along with haze are limiting factors in producing accurate regression equations to predict water clarity and are why imagery should be chosen on clear satellite-overpass days (Olmanson and others, 2008). Measurements were omitted if information was available to determine that measured SDTs were more than two-thirds the lake depth (which occurs 

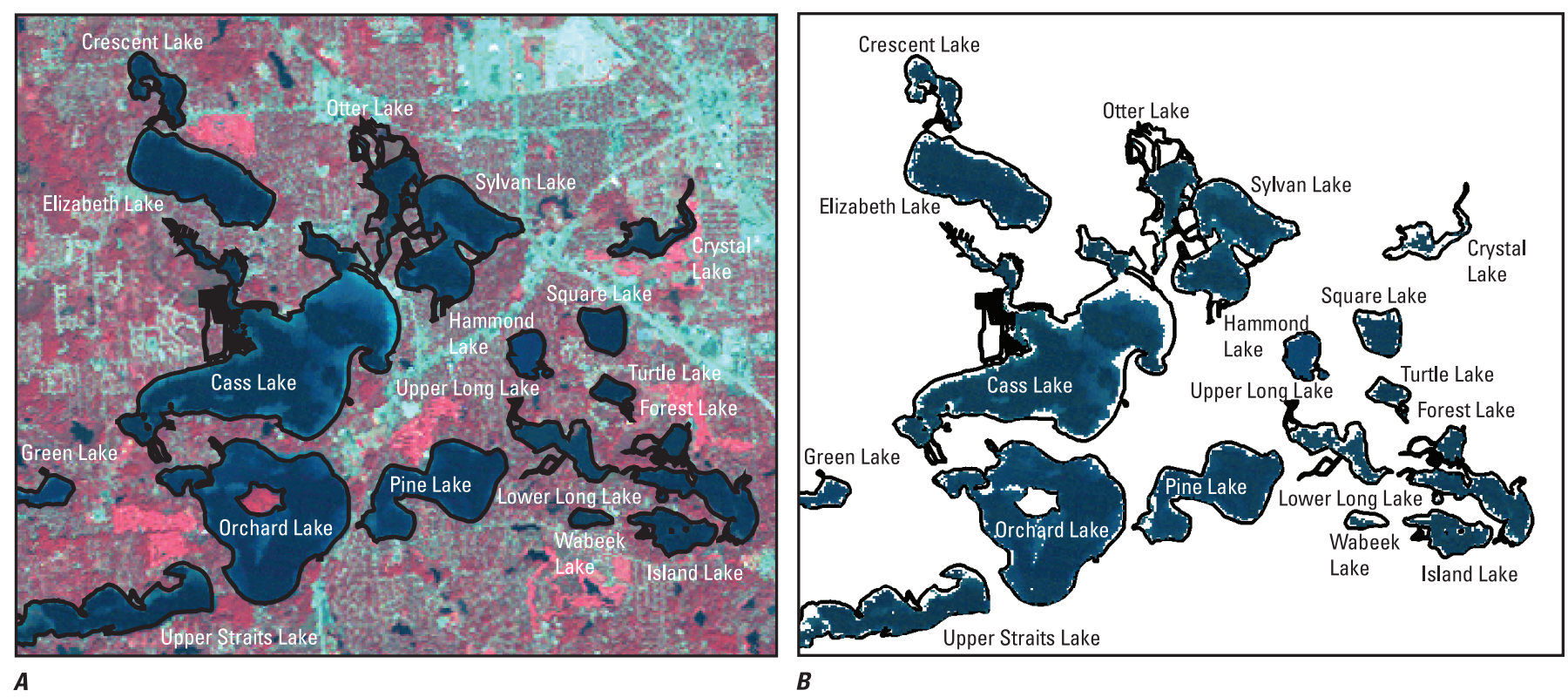

A
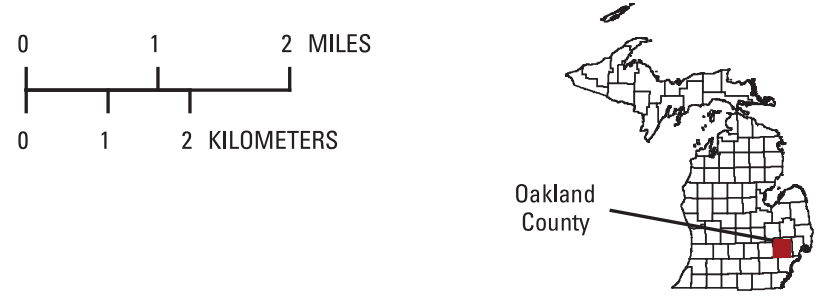

Figure 2. Landsat path 20 satellite image for September 22, 2004, in Oakland County, Michigan, for $\boldsymbol{A}$, before satellite-data processing and $\boldsymbol{B}$, after satellite-data processing.

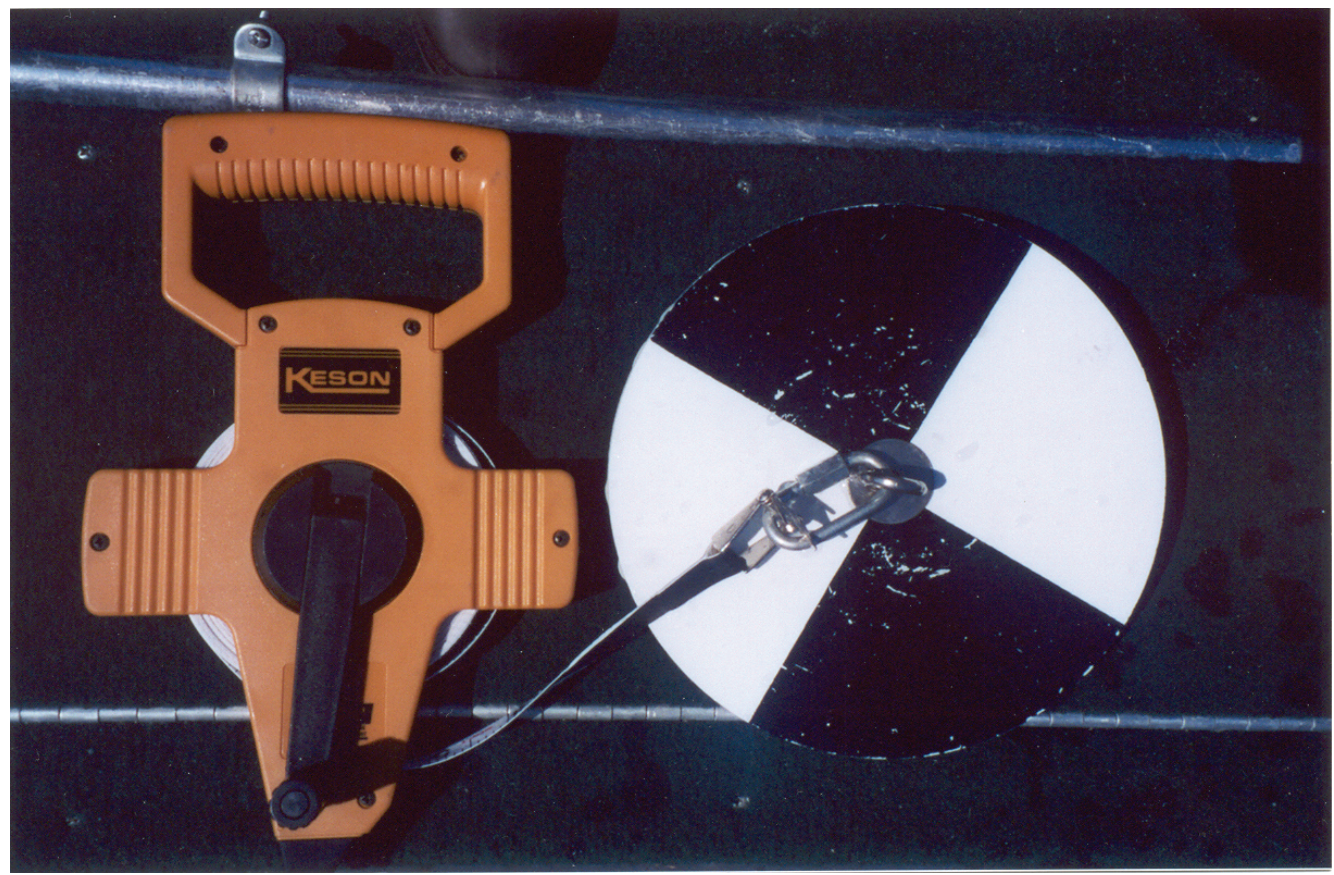

Figure 3. Example of Secchi disk used to measure water clarity in lakes. 
mostly in shallow lakes), because of possible interference from the lake bottom.

Occasionally, latitude and longitude locations of measurements plotted outside the lake. In these circumstances, the coordinates were changed to correspond to the deepest location if a bathymetric map was available. If a bathymetric map could not be located, the measurement was omitted. Some lakes did not have latitude and longitude for measurements, nor could accurate bathymetric maps be located; these measurements were omitted. Table 3 summarizes measurements per Landsat-satellite scene.

\section{Relating Field Data to Landsat-Satellite Imagery}

The field SDT measurements were related to the Landsatsatellite imagery by using the AOI method documented in Fuller and others (2004) and an alternative Gethist method that selects a portion of the open-water areas remaining after satellite-data processing (as documented in Olmanson and others, 2001). Mean values for each band in the Landsat-satellite imagery then were used in two equations (differing in the bands used) to produce statewide TSI (SDT) predictions for 2003-05 and 2007-08.

\section{AOI Method To Select Open-Water Areas}

AOIs containing approximately nine cells were established around each measurement, and the average band values were recorded. Taking an average for each band in its AOI was found to smooth the radiometric noise and to produce more accurate predicted SDT values (Olmanson and others, 2001). Average band values for each measurement were used in a statistical analysis program to determine the regression equation specific to each path or scene of Landsat-satellite data.

\section{Gethist Method To Select Open-Water Areas}

The open-water areas remaining after satellite-data processing for lakes greater than 20 acres were used in the Gethist program documented in Olmanson and others (2001). The Gethist program further reduced the remaining areas in each lake to identify the darkest pixels that should represent deeper open water. Specifications were set to ignore zeros, use 50 percent of the histogram, and use the bottom $\mathrm{N}$ percent pixels to represent the darkest pixels. The Gethist program returned mean values for each band of the Landsat-satellite imagery for each inland lake. The output was used in a statistical analysis program to produce regression equations specific to each path of satellite data.

\section{Trophic State Index Calculation for SDT}

Tibco Spotfire S+ 8.1 software was used for multiple regression calculations for each path. The equation documented in Fuller and others (2004) was applied to each path of satellite data for both the AOI and the Gethist method:

$$
\ln (\mathrm{SDT})=a(\text { band } 1)+b(\text { band } 2)+c(\text { band } 3)+d
$$

The resulting equation used the natural log of SDT for the dependent variable, and the independent variables were bands 1,2 , and 3 .

The equation used in Olmanson and others (2001) and Kloiber and others (2002) was applied to each path of satellite data for both the AOI and the Gethist method:

$$
\ln (\mathrm{SDT})=a(\text { band } 1 / \text { band } 3)+b(\text { band } 1)+c
$$

The natural log of SDT was the dependent variable, and the independent variables were a ratio of band 1 and 3 , and band 1 . The variables $a, b$, and $c$ were derived coefficients from the regression equation.

TSI values then could be computed on the natural log of the SDT images derived previously using the equation from Carlson (1977).

The measured TSI (SDT) and SDT values were compared to the predicted TSI (SDT) and SDT values from equations 1 and 2. Results for both 2003-05 and 2007-08, by path, are listed in table 3 . For the 2003-05 years, path 21, row 28 did not have an adequate number of measurements available during the Landsat-satellite imagery-acquisition date, so the regression equation from path 21 , rows 29 to 31 was applied to that Landsat-satellite scene. A comparison (as percentages) for both sets of years of data using both methods and equations to measured TSI (SDT) and SDT is presented in table 4. Scatterplots with $\mathrm{R}^{2}$ values are shown on figures $4 A$ and $4 B$ for 2003-05 and 2007-08, respectively, for all measured values of TSI (SDT) and SDT for the AOI lake-average method and the Gethist method generated by use of equations 1 and 2 . Scatterplots comparing the predicted TSI (SDT) for all lakes with desirable pixels from 2003-05 and 2007-08 are shown for equations 1 and 2 on figure 5 . The predicted paths were merged together to produce statewide 2003-05 and 2007-08 predictions on figures $6 A$ and $6 B$, respectively. Appendixes 1 and 2 list the measurements used for the regression equations. 
Table 3. Landsat-image and calibration-model data for Michigan inland lakes, 2003-05 and 2007-08.

[SDT, Secchi-disk transparency; AOI, area of interest; $\mathrm{R}^{2}$, coefficient of determination; SEE, Standard Error of Estimate; TM, Thematic Mapper; <, less than]

\begin{tabular}{|c|c|c|c|c|c|c|c|c|c|c|c|c|c|c|c|c|c|}
\hline $\begin{array}{l}\text { Image } \\
\text { date }\end{array}$ & Path & Rows & $\begin{array}{l}\text { Number } \\
\text { of } \\
\text { images }\end{array}$ & Satellite & $\begin{array}{l}\text { Percent } \\
\text { cloud } \\
\text { cover }\end{array}$ & $\begin{array}{l}\text { Days } \\
\text { prior }\end{array}$ & $\begin{array}{l}\text { Days } \\
\text { past }\end{array}$ & $\begin{array}{l}\text { Number of } \\
\text { measure- } \\
\text { ments }\end{array}$ & $\begin{array}{l}\text { SDT } \\
\text { range } \\
(\mathrm{m})\end{array}$ & $\begin{array}{l}\text { SDT } \\
\text { range } \\
\text { (ft) }\end{array}$ & $\mathbf{R}^{2}$ & SEE & $\begin{array}{l}\text { Number } \\
\text { of lakes } \\
\text { assessed }\end{array}$ & Equation 1 & $\mathbf{R}^{2}$ & SEE & Equation 2 \\
\hline \multicolumn{18}{|c|}{ 2003-05 SDT AOI } \\
\hline $9 / 22 / 2004$ & 20 & $30-31$ & 2 & Landsat TM 5 & $<10$ & 6 & 4 & 20 & $1.5-7.3$ & $5.0-24.0$ & 0.72 & 0.227 & 573 & $\begin{array}{c}\mathrm{x}=\mathrm{B} 1(0.0190)+\mathrm{B} 2(0.1355)+ \\
\mathrm{B} 3(-0.5709)+4.6406\end{array}$ & 0.67 & 0.240 & $\begin{aligned} \mathrm{x}=\mathrm{B} 1 / \mathrm{B} 3(1.4334)+ \\
\quad \mathrm{B} 1(-0.0339)+-3.2019\end{aligned}$ \\
\hline 9/13/2004 & 21 & *28-31 & 4 & Landsat TM 5 & $<10$ & 8 & 6 & 72 & $0.8-8.5$ & $2.5-28.0$ & 0.70 & 0.244 & 1597 & $\begin{array}{c}\mathrm{x}=\mathrm{B} 1(0.0976)+\mathrm{B} 2(-0.0690)+ \\
\mathrm{B} 3(-0.2452)+0.7801\end{array}$ & 0.66 & 0.258 & $\begin{array}{l}\mathrm{x}=\mathrm{B} 1 / \mathrm{B} 3(1.1820)+ \\
\quad \mathrm{B} 1(0.0035)+-3.4462\end{array}$ \\
\hline $9 / 20 / 2004$ & 22 & $28-31$ & 4 & Landsat TM 5 & $<10$ & 7 & 6 & 49 & $0.9-5.9$ & $3.0-19.0$ & 0.72 & 0.194 & 1368 & $\begin{array}{c}\mathrm{x}=\mathrm{B} 1(0.0210)+\mathrm{B} 2(0.0482)+ \\
\mathrm{B} 3(-0.3498)+3.0269\end{array}$ & 0.69 & 0.202 & $\begin{array}{l}\mathrm{x}=\mathrm{B} 1 / \mathrm{B} 3(0.7531)+ \\
\mathrm{B} 1(-0.0326)+-0.7185\end{array}$ \\
\hline $9 / 21 / 2005$ & 24 & 27 & 1 & Landsat TM 5 & $<10$ & 0 & 5 & 10 & $2.0-5.3$ & $6.5-17.5$ & 0.67 & 0.227 & 72 & $\begin{array}{c}\mathrm{x}=\mathrm{B} 1(0.2464)+\mathrm{B} 2(-0.1678)+ \\
\mathrm{B} 3(-0.2477)+-4.7251\end{array}$ & 0.66 & 0.217 & $\begin{aligned} \mathrm{x}= & \mathrm{B} 1 / \mathrm{B} 3(1.0829) \\
& +\mathrm{B} 1(0.1590)+ \\
& -10.4585\end{aligned}$ \\
\hline $7 / 19 / 2005$ & 24 & 28 & 1 & Landsat TM 5 & $<10$ & 0 & 6 & 15 & $2.1-6.7$ & $7.0-22.0$ & 0.72 & 0.188 & 463 & $\begin{array}{c}\mathrm{x}=\mathrm{B} 1(0.0343)+\mathrm{B} 2(-0.1110)+ \\
\mathrm{B} 3(-0.3256)+5.3142\end{array}$ & 0.66 & 0.198 & $\begin{array}{l}\mathrm{x}=\mathrm{B} 1 / \mathrm{B} 3(0.9666)+ \\
\quad \mathrm{B} 1(-0.0910)+1.7341\end{array}$ \\
\hline $8 / 22 / 2003$ & 25 & 28 & 1 & Landsat TM 5 & $<10$ & 10 & 6 & 12 & $6.0-20.5$ & $1.8-6.3$ & 0.55 & 0.310 & 172 & $\begin{array}{c}\mathrm{x}=\mathrm{B} 1(0.0491)+\mathrm{B} 2(0.2245)+ \\
\mathrm{B} 3(-0.3501)+-0.5287\end{array}$ & 0.45 & 0.325 & $\begin{array}{l}\mathrm{x}=\mathrm{B} 1 / \mathrm{B} 3(0.7459)+ \\
\mathrm{B} 1(0.0326)+-3.2937\end{array}$ \\
\hline \multicolumn{18}{|c|}{ 2003-05 SDT Gethist } \\
\hline $9 / 22 / 2004$ & 20 & $30-31$ & 2 & Landsat TM 5 & $<10$ & 6 & 4 & 22 & $1.5-7.3$ & $5.0-24.0$ & 0.78 & 0.220 & 573 & $\begin{array}{c}\mathrm{x}=\mathrm{B} 1(0.0198)+\mathrm{B} 2(0.2138)+ \\
\mathrm{B} 3(-0.7569)+5.2799\end{array}$ & 0.73 & 0.238 & $\begin{array}{l}\mathrm{x}=\mathrm{B} 1 / \mathrm{B} 3(1.6413)+ \\
\quad \mathrm{B} 1(-0.0196)+-4.8612\end{array}$ \\
\hline 9/13/2004 & 21 & $* 28-31$ & 4 & Landsat TM 5 & $<10$ & 8 & 6 & 75 & $0.8-8.5$ & $2.5-28$ & 0.72 & 0.233 & 1597 & $\begin{array}{c}\mathrm{x}=\mathrm{B} 1(0.1112)+\mathrm{B} 2(-0.0496)+ \\
\mathrm{B} 3(-0.3008)+0.4164\end{array}$ & 0.69 & 0.243 & $\begin{array}{l}\mathrm{x}=\mathrm{B} 1 / \mathrm{B} 3(1.3398)+ \\
\quad \mathrm{B} 1(0.0104)+-4.4821\end{array}$ \\
\hline $9 / 20 / 2004$ & 22 & $28-31$ & 4 & Landsat TM 5 & $<10$ & 7 & 6 & 50 & $0.9-5.9$ & $3-19.0$ & 0.74 & 0.187 & 1368 & $\begin{array}{c}\mathrm{x}=\mathrm{B} 1(0.0159)+\mathrm{B} 2(0.0898)+ \\
\mathrm{B} 3(-0.4580)+3.5664\end{array}$ & 0.72 & 0.192 & $\begin{array}{l}\mathrm{x}=\mathrm{B} 1 / \mathrm{B} 3(0.8592)+ \\
\mathrm{B} 1(-0.0380)+-1.0662\end{array}$ \\
\hline $1 / 11 / 1900$ & 24 & 27 & 1 & Landsat TM 5 & $<10$ & 0 & 5 & 10 & $2.0-5.3$ & $6.5-17.5$ & 0.73 & 0.207 & 72 & $\begin{array}{c}\mathrm{x}=\mathrm{B} 1(0.2417)+\mathrm{B} 2(-0.0502)+ \\
\mathrm{B} 3(-0.4146)+-4.4840\end{array}$ & 0.73 & 0.194 & $\begin{array}{l}\mathrm{x}=\mathrm{B} 1 / \mathrm{B} 3(1.1798)+ \\
\quad \mathrm{B} 1(0.1401)+-10.0580\end{array}$ \\
\hline $7 / 19 / 2005$ & 24 & 28 & 1 & Landsat TM 5 & $<10$ & 0 & 6 & 15 & $2.1-6.7$ & $7.0-22.0$ & 0.77 & 0.205 & 463 & $\begin{array}{c}\mathrm{x}=\mathrm{B} 1(0.0883)+\mathrm{B} 2(0.2556)+ \\
\mathrm{B} 3(-0.5212)+-1.4099\end{array}$ & 0.73 & 0.214 & $\begin{aligned} \mathrm{x}=\mathrm{B} 1 / \mathrm{B} 3(0.7688)+ \\
\quad \mathrm{B} 1(0.1562)+-9.6935\end{aligned}$ \\
\hline $8 / 22 / 2003$ & 25 & 28 & 1 & Landsat TM 5 & $<10$ & 10 & 6 & 12 & $6.0-20.5$ & $1.8-6.3$ & 0.68 & 0.262 & 172 & $\begin{array}{c}\mathrm{x}=\mathrm{B} 1(0.1840)+\mathrm{B} 2(0.0937)+ \\
\mathrm{B} 3(-0.4114)+-4.0418\end{array}$ & 0.65 & 0.256 & $\begin{array}{l}\mathrm{x}=\mathrm{B} 1 / \mathrm{B} 3(1.1529)+ \\
\mathrm{B} 1(0.0945)+-7.8513\end{array}$ \\
\hline
\end{tabular}


Table 3. Landsat-image and calibration-model data for Michigan inland lakes, 2003-05 and 2007-08. - Continued

[SDT, Secchi-disk transparency; AOI, area of interest; $\mathrm{R}^{2}$, coefficient of determination; SEE, Standard Error of Estimate; TM, Thematic Mapper; $<$, less than]

\begin{tabular}{|c|c|c|c|c|c|c|c|c|c|c|c|c|c|c|c|c|c|}
\hline $\begin{array}{l}\text { Image } \\
\text { date }\end{array}$ & Path & Rows & $\begin{array}{c}\text { Number } \\
\text { of } \\
\text { images }\end{array}$ & Satellite & $\begin{array}{l}\text { Percent } \\
\text { cloud } \\
\text { cover }\end{array}$ & $\begin{array}{l}\text { Days } \\
\text { prior }\end{array}$ & $\begin{array}{l}\text { Days } \\
\text { past }\end{array}$ & $\begin{array}{c}\text { Number of } \\
\text { measure- } \\
\text { ments }\end{array}$ & $\begin{array}{c}\text { SDT } \\
\text { range } \\
\text { (m) }\end{array}$ & $\begin{array}{c}\text { SDT } \\
\text { range } \\
\text { (ft) }\end{array}$ & $\mathbf{R}^{2}$ & SEE & $\begin{array}{c}\text { Number } \\
\text { of lakes } \\
\text { assessed }\end{array}$ & Equation 1 & $\mathbf{R}^{2}$ & SEE & Equation 2 \\
\hline \multicolumn{18}{|c|}{ 2007-08 SDT AOI } \\
\hline $8 / 30 / 2007$ & 20 & $30-31$ & 2 & Landsat TM 5 & $<10$ & 6 & 3 & 18 & $1.8-4.9$ & $6.0-16.0$ & 0.75 & 0.155 & 506 & $\begin{array}{c}\mathrm{x}=\mathrm{B} 1(0.1320)+\mathrm{B} 2(-0.0021)+ \\
\mathrm{B} 3(-0.4418)+0.2371\end{array}$ & 0.74 & 0.155 & $\begin{aligned} \mathrm{x}=\mathrm{B} 1 / \mathrm{B} 3(1.4583)+ \\
\quad \mathrm{B} 1(0.0176)+-5.4392\end{aligned}$ \\
\hline $9 / 22 / 2007$ & 21 & $28-31$ & 3 & Landsat TM 5 & $<10$ & 7 & 0 & 68 & $0.8-6.7$ & $2.5-22.0$ & 0.69 & 0.205 & 1603 & $\begin{array}{c}\mathrm{x}=\mathrm{B} 1(0.0379)+\mathrm{B} 2(0.0366)+ \\
\mathrm{B} 3(-0.4568)+4.0436\end{array}$ & 0.66 & 0.213 & $\begin{aligned} \mathrm{x}= & \mathrm{B} 1 / \mathrm{B} 3(1.2140)+ \\
& \mathrm{B} 1(-0.0544)+-1.2159\end{aligned}$ \\
\hline $6 / 25 / 2007$ & 22 & 28 & 1 & Landsat TM 5 & $<10$ & 0 & 3 & 15 & $2.4-6.4$ & $8.0-21.0$ & 0.70 & 0.182 & 349 & $\begin{array}{c}\mathrm{x}=\mathrm{B} 1(0.0810)+\mathrm{B} 2(0.0499)+ \\
\mathrm{B} 3(-0.2736)+-0.2435\end{array}$ & 0.74 & 0.162 & $\begin{aligned} \mathrm{x}= & \mathrm{B} 1 / \mathrm{B} 3(1.1476)+ \\
& \mathrm{B} 1(0.0164)+-4.0149\end{aligned}$ \\
\hline $9 / 13 / 2007$ & 22 & $29-31$ & 3 & Landsat TM 5 & $<10$ & 5 & 7 & 56 & $2.5-23.0$ & $0.8-7.0$ & 0.73 & 0.205 & 892 & $\begin{array}{c}\mathrm{x}=\mathrm{B} 1(0.0844)+\mathrm{B} 2(-0.1191)+ \\
\mathrm{B} 3(-0.1500)+1.0328\end{array}$ & 0.63 & 0.236 & $\begin{array}{l}\mathrm{x}=\mathrm{B} 1 / \mathrm{B} 3(0.8629)+ \\
\mathrm{B} 1(0.0000)+-2.2677\end{array}$ \\
\hline $8 / 3 / 2007$ & 23 & 28 & 1 & Landsat TM 5 & $<10$ & 0 & 5 & 15 & $2.9-6.1$ & $9.5-20.0$ & 0.74 & 0.121 & 464 & $\begin{array}{c}\mathrm{x}=\mathrm{B} 1(0.1313)+\mathrm{B} 2(-0.0065)+ \\
\mathrm{B} 3(-0.1344)+-3.5666\end{array}$ & 0.71 & 0.122 & $\begin{array}{l}\mathrm{x}=\mathrm{B} 1 / \mathrm{B} 3(0.3908)+ \\
\quad \mathrm{B} 1(0.0915)+-4.9307\end{array}$ \\
\hline $7 / 27 / 2008$ & 24 & $27-28$ & 2 & Landsat TM 5 & $<10$ & 0 & 4 & 17 & $2.1-5.0$ & $6.8-16.4$ & 0.67 & 0.154 & 432 & $\begin{array}{c}\mathrm{x}=\mathrm{B} 1(0.0694)+\mathrm{B} 2(0.0070)+ \\
\mathrm{B} 3(-0.0852)+-1.7354\end{array}$ & 0.73 & 0.134 & $\begin{array}{l}\mathrm{x}=\mathrm{B} 1 / \mathrm{B} 3(0.4388)+ \\
\quad \mathrm{B} 1(0.0485)+-3.3596\end{array}$ \\
\hline $8 / 3 / 2008$ & 25 & 28 & 1 & Landsat TM 5 & $<10$ & 0 & 3 & 14 & $1.7-7.3$ & $5.5-24.0$ & 0.79 & 0.233 & 168 & $\begin{array}{c}\mathrm{x}=\mathrm{B} 1(-0.0992)+\mathrm{B} 2(-0.2703)+ \\
\mathrm{B} 3(0.1156)+10.7408\end{array}$ & 0.65 & 0.290 & $\begin{array}{l}\mathrm{x}=\mathrm{B} 1 / \mathrm{B} 3(0.0025)+ \\
\mathrm{B} 1(-0.1497)+9.9124\end{array}$ \\
\hline \multicolumn{18}{|c|}{ 2007-08 SDT Gethist } \\
\hline $8 / 30 / 2007$ & 20 & $30-31$ & 2 & Landsat TM 5 & $<10$ & 6 & 3 & 18 & $1.8-4.9$ & $6.0-16.0$ & 0.72 & 0.165 & 506 & $\begin{array}{c}\mathrm{x}=\mathrm{B} 1(0.1810)+\mathrm{B} 2(0.0617)+ \\
\mathrm{B} 3(-0.6804)+-0.5065\end{array}$ & 0.72 & 0.159 & $\begin{array}{l}\mathrm{x}=\mathrm{B} 1 / \mathrm{B} 3(2.1944)+ \\
\quad \mathrm{B} 1(0.0401)+-9.6437\end{array}$ \\
\hline $9 / 22 / 2007$ & 21 & $28-31$ & 3 & Landsat TM 5 & $<10$ & 7 & 0 & 72 & $0.8-7.0$ & $2.5-23.0$ & 0.76 & 0.182 & 1603 & $\begin{array}{c}\mathrm{x}=\mathrm{B} 1(0.0117)+\mathrm{B} 2(0.1001)+ \\
\mathrm{B} 3(-0.5401)+5.0105\end{array}$ & 0.75 & 0.183 & $\begin{aligned} \mathrm{x}= & \mathrm{B} 1 / \mathrm{B} 3(1.3083)+ \\
& \mathrm{B} 1(-0.0631)+-1.2937\end{aligned}$ \\
\hline $6 / 25 / 2007$ & 22 & 28 & 1 & Landsat TM 5 & $<10$ & 0 & 3 & 15 & $2.4-6.4$ & $8.0-21.0$ & 0.73 & 0.174 & 349 & $\begin{array}{c}\mathrm{x}=\mathrm{B} 1(0.0569)+\mathrm{B} 2(0.0919)+ \\
\mathrm{B} 3(-0.2803)+0.4328\end{array}$ & 0.74 & 0.161 & $\begin{aligned} \mathrm{x}= & \mathrm{B} 1 / \mathrm{B} 3(1.0580)+ \\
& \mathrm{B} 1(0.0103)+-3.3394\end{aligned}$ \\
\hline 9/13/2007 & 22 & $29-31$ & 3 & Landsat TM 5 & $<10$ & 5 & 7 & 56 & $2.5-23.0$ & $0.8-7.0$ & 0.72 & 0.207 & 892 & $\begin{array}{c}\mathrm{x}=\mathrm{B} 1(0.0811)+\mathrm{B} 2(-0.0860)+ \\
\mathrm{B} 3(-0.1948)+1.1367\end{array}$ & 0.67 & 0.223 & $\begin{array}{l}\mathrm{x}=\mathrm{B} 1 / \mathrm{B} 3(0.9800)+ \\
\quad \mathrm{B} 1(-0.0046)+-2.5253\end{array}$ \\
\hline $8 / 3 / 2007$ & 23 & 28 & 1 & Landsat TM 5 & $<10$ & 0 & 5 & 15 & $2.9-6.1$ & $9.5-20.0$ & 0.67 & 0.135 & 464 & $\begin{array}{c}\mathrm{x}=\mathrm{B} 1(0.1308)+\mathrm{B} 2(0.0088)+ \\
\mathrm{B} 3(-0.1204)+-3.8703\end{array}$ & 0.67 & 0.130 & $\begin{array}{l}\mathrm{x}=\mathrm{B} 1 / \mathrm{B} 3(0.3153)+ \\
\mathrm{B} 1(0.1069)+-5.2894\end{array}$ \\
\hline $7 / 27 / 2008$ & 24 & $27-28$ & 2 & Landsat TM 5 & $<10$ & 0 & 4 & 18 & $2.1-5.6$ & $6.8-18.3$ & 0.68 & 0.173 & 432 & $\begin{array}{c}\mathrm{x}=\mathrm{B} 1(0.0289)+\mathrm{B} 2(0.1545)+ \\
\mathrm{B} 3(-0.1423)+-1.3854\end{array}$ & 0.68 & 0.166 & $\begin{array}{l}\mathrm{x}=\mathrm{B} 1 / \mathrm{B} 3(0.4080)+ \\
\quad \mathrm{B} 1(0.0512)+-3.3810\end{array}$ \\
\hline $8 / 3 / 2008$ & 25 & 28 & 1 & Landsat TM 5 & $<10$ & 0 & 3 & 14 & $1.7-7.3$ & $5.5-24.0$ & 0.81 & 0.224 & 168 & $\begin{array}{c}\mathrm{x}=\mathrm{B} 1(0.1929)+\mathrm{B} 2(-0.3452)+ \\
\mathrm{B} 3(-0.2916)+1.9305\end{array}$ & 0.73 & 0.256 & $\begin{array}{l}\mathrm{x}=\mathrm{B} 1 / \mathrm{B} 3(1.6371)+ \\
\mathrm{B} 1(-0.0239)+-3.3531\end{array}$ \\
\hline
\end{tabular}

${ }^{*}$ No in-situ measurements available in Path 22 Row 28. 
Table 4. Results comparing methods using equations 1 and 2 for 2003-05 and 2007-08 in percent for measured Secchi-disk transparency values within 2, 5, and 10 feet of the predicted Secchi-disk transparency; and percent for measured Trophic State Index values within 2, 5, and 10 units of the predicted Trophic State Index values for Michigan inland lakes.

[SDT, Secchi-disk transparency; TSI, Trophic State Index; AOI, area of interest; Eq, equation; LakeAve, Lake average; all data are in percent]

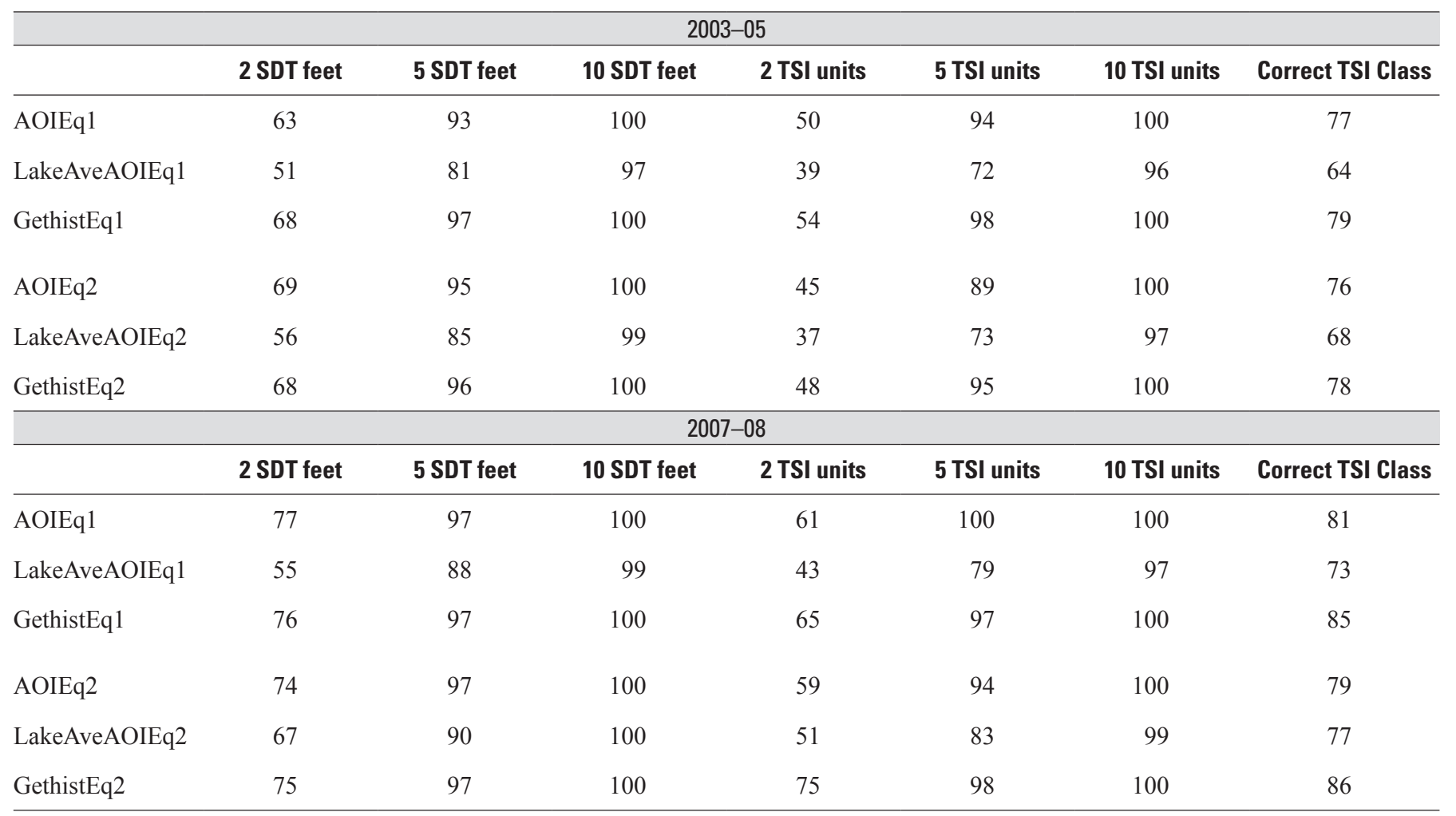


$\boldsymbol{A}$
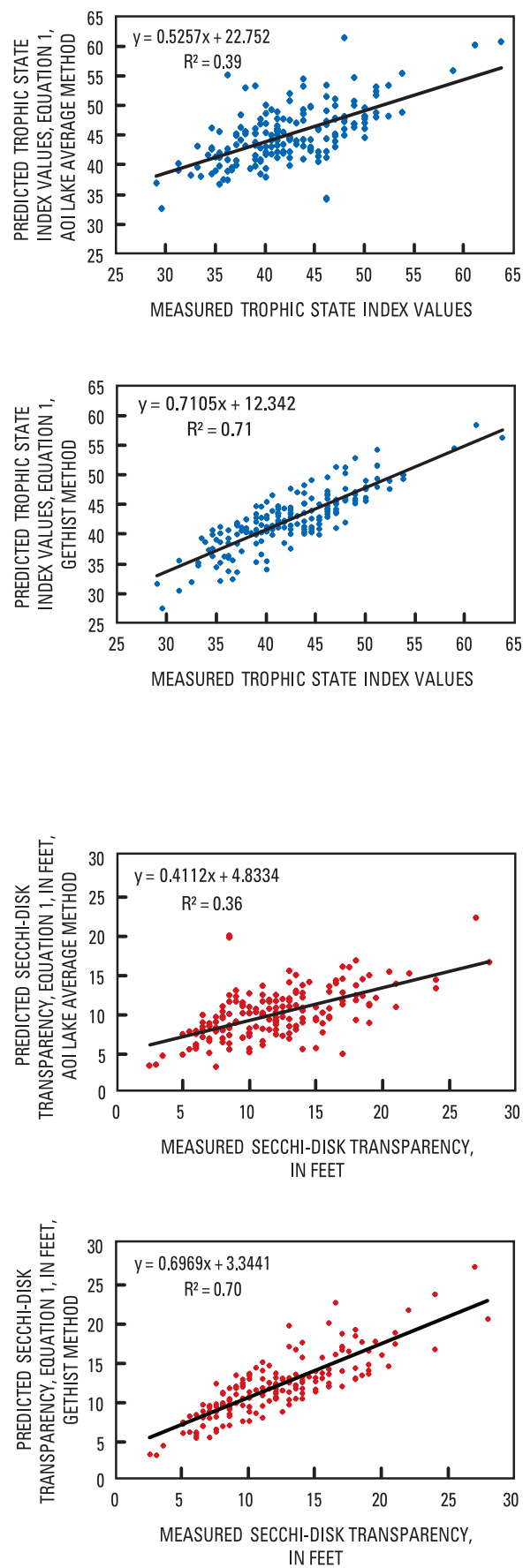

B
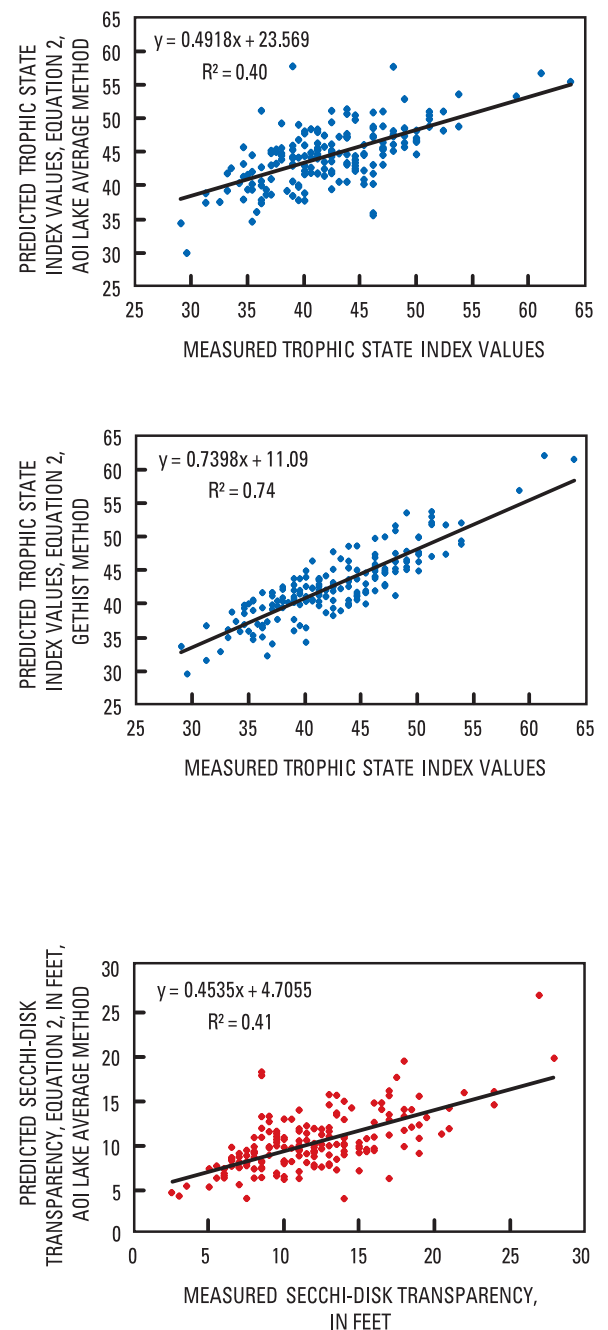

IN FEET

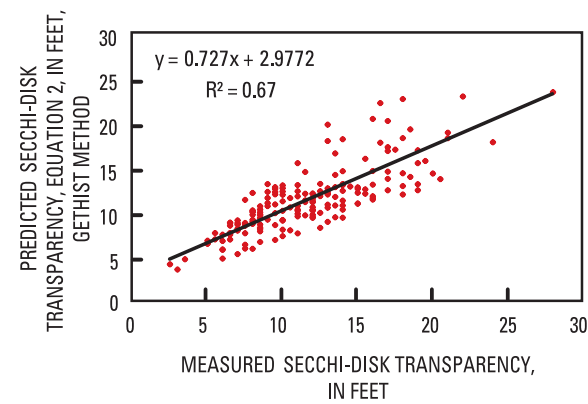

C
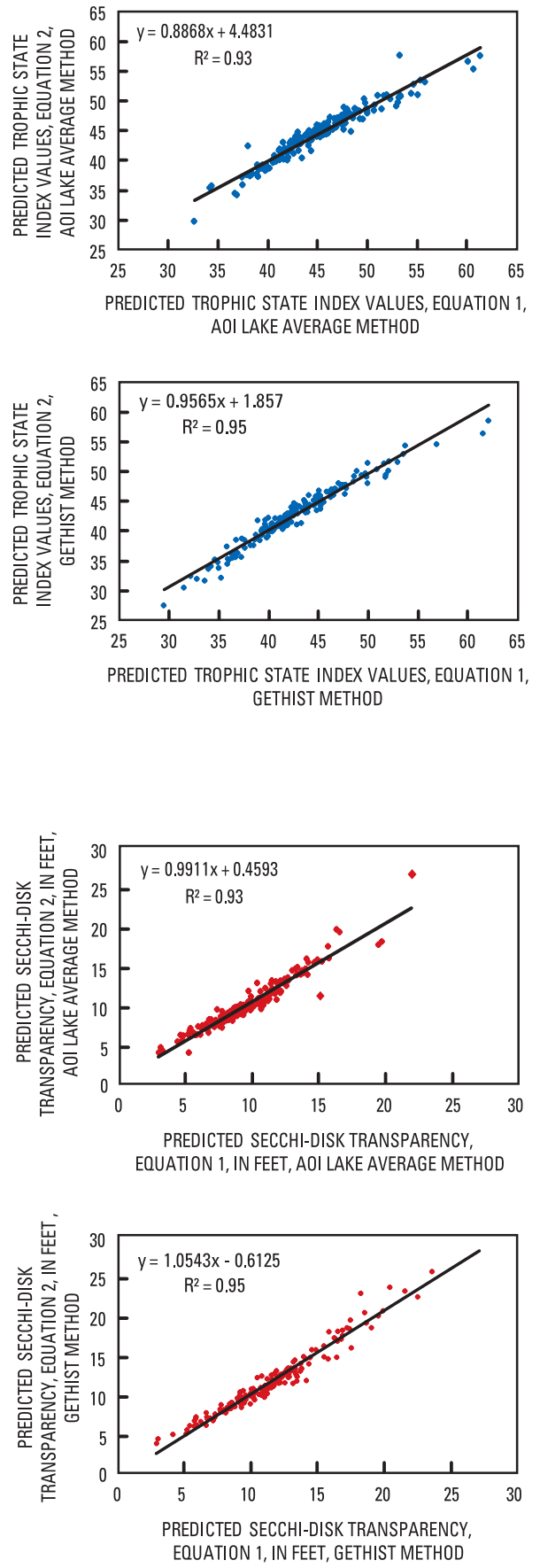

Figure 4A. Scatterplots for 2003-05 of $A$, Michigan measured Trophic State Index (TSI) values and Secchi-disk transparency (SDT) values, in feet, to predicted TSI and SDT values using equation 1 for both the area of interest (AOI) lake-average method and the Gethist method; $B$, measured TSI values and SDT values, in feet, to predicted TSI and SDT values using equation 2 for both the AOI lakeaverage method and the Gethist method; and $C$, predicted TSI and SDT values using equation 1 to predicted TSI and SDT values using equation 2. 
$\boldsymbol{A}$
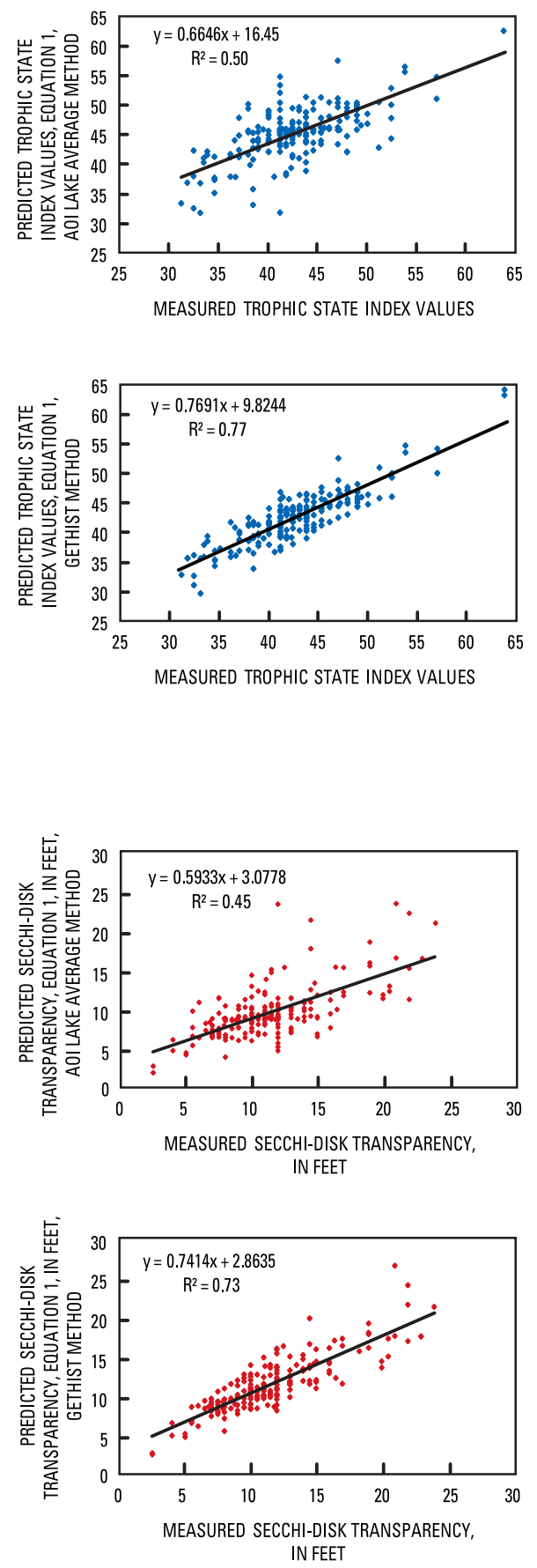

$B$
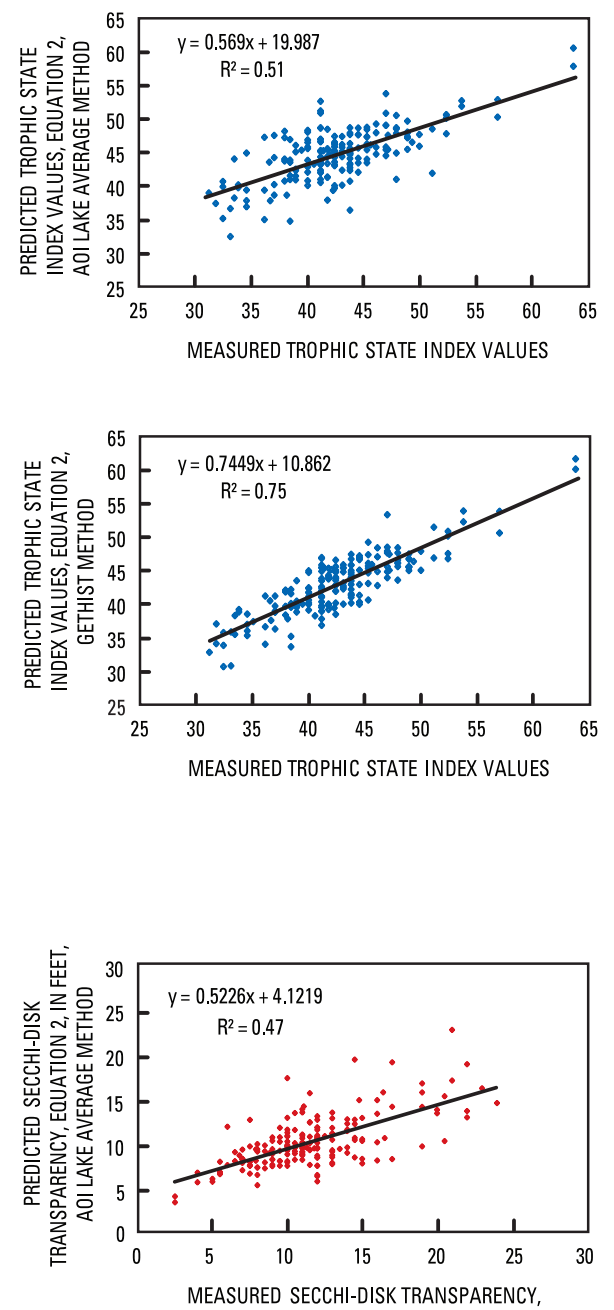

IN FEET

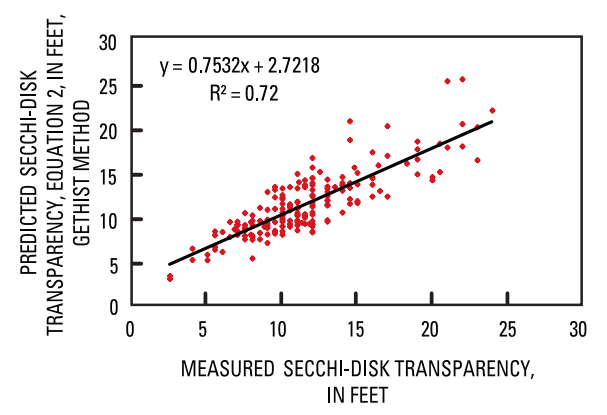

C
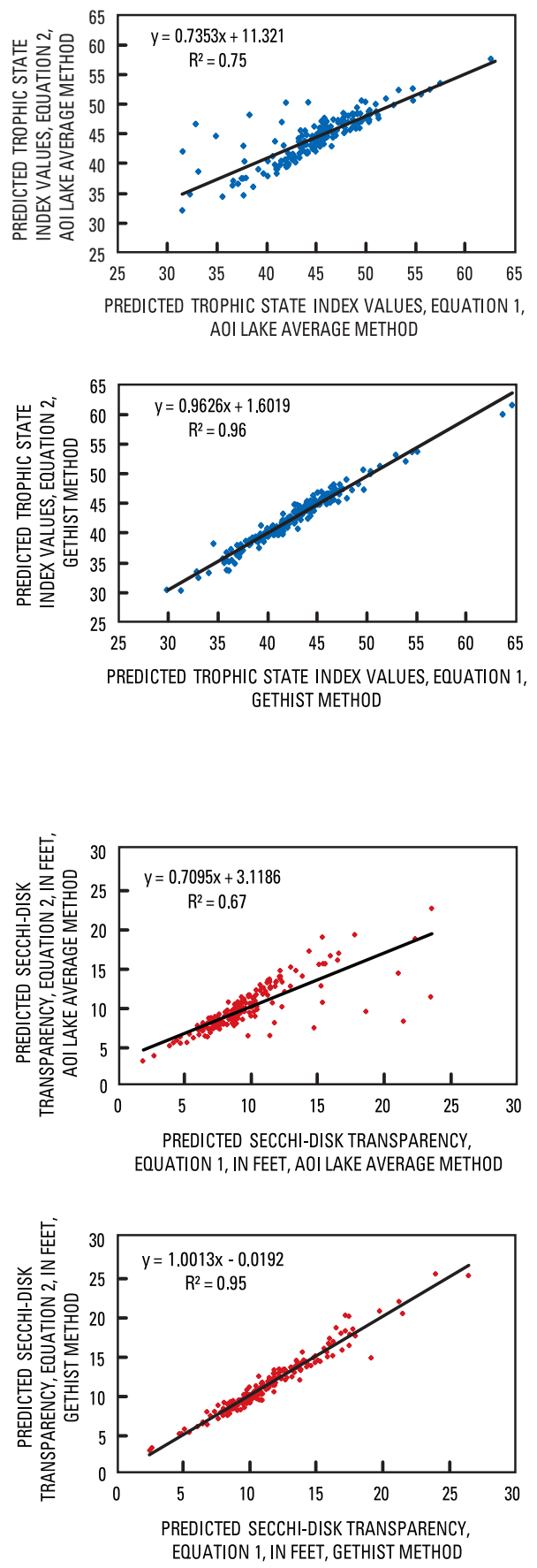

Figure 4B. Scatterplots for 2007-08 of $A$, Michigan measured Trophic State Index (TSI) values and Secchi-disk transparency (SDT) values, in feet, to predicted TSI and SDT values using equation 1 for both the area of interest (AOI) lake-average method and the Gethist method; $B$, measured TSI values and SDT values, in feet, to predicted TSI and SDT values using equation 2 for both the AOI lakeaverage method and the Gethist method; and $C$, predicted TSI and SDT values using equation 1 to predicted TSI and SDT values using equation 2. 
$\boldsymbol{A}$

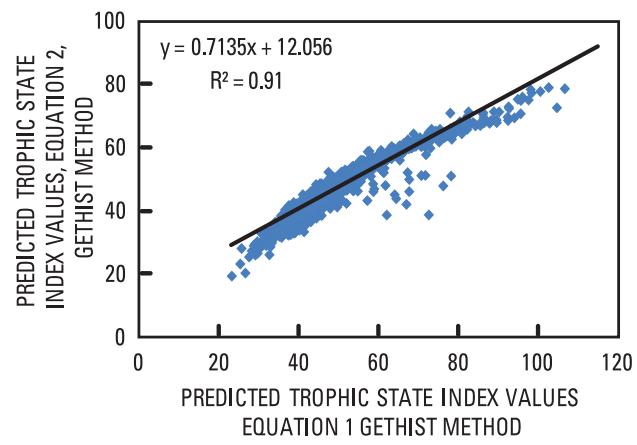

B

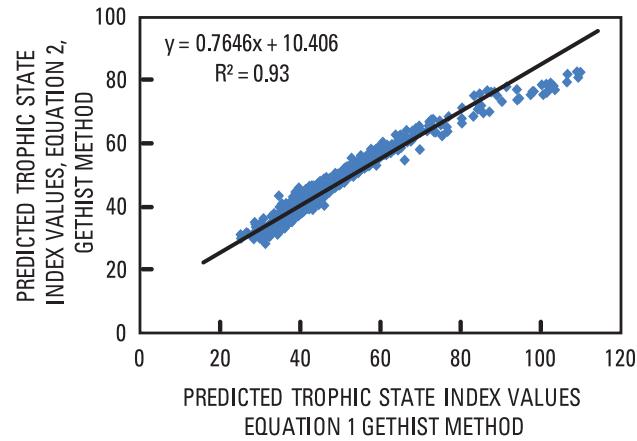

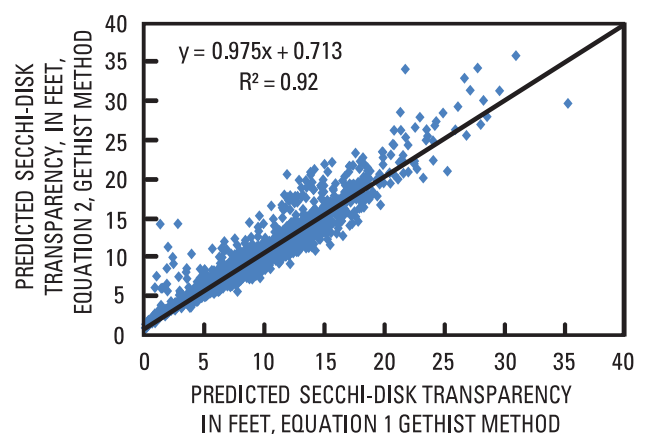

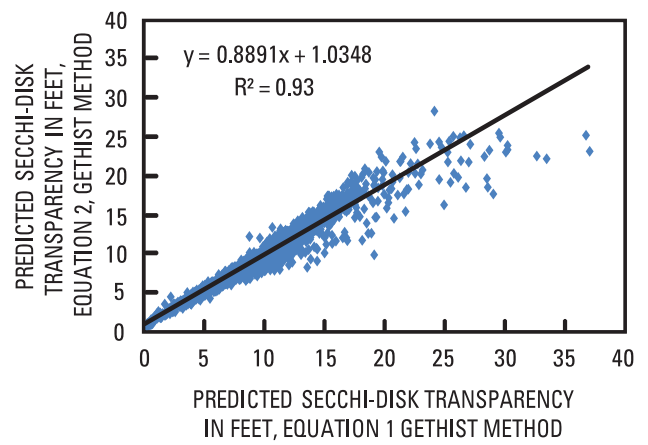

Figure 5. Scatterplots of $\boldsymbol{A}, 2003-05$ and $\boldsymbol{B}, 2007-08$ for Michigan inland lakes greater than 20 acres with available open-water areas for statewide predicted Trophic State Index values and Secchi-disk transparency, in feet, using the Gethist method for equations 1 and 2.

\section{Regression Equations and Tests of Significance}

Fisher's Transformation (Yamane, 1973) was used to test the difference of two correlation coefficients to determine whether there was a statistically significant difference between the AOI lake-average method and the Gethist method, and also between equations 1 and 2 . The square root of the $\mathrm{R}^{2}$ values was used for Fisher's Transformation of R. Results of Fisher's Transformation (tables 5 and 6) higher than 2.579 mean that differences were statistically significant at the 99 -percent confidence level, whereas those lower than 1.96 mean that differences were not statistically significant even at the 95 -percent confidence level.

\section{Results}

Fourteen Landsat 5 satellite scenes were processed to produce two statewide predicted TSI (SDT) and SDT layers for Michigan inland lakes. One scene - path 23, row 28 in the 2003-05 period - did not have an adequate number of field measurements remaining after removing lakes effected by clouds, cloud shadows, and haze to produce a regression equation. Although approximately 20 field measurements within each Landsat-satellite scene are desirable, fewer measurements were available for a few scenes, especially in the Upper Peninsula. Even so, the $\mathrm{R}^{2}$ values from the resulting regression equations were still comparable to those for other satellite paths. All 14 Landsat-satellite scenes had coverage for 2007-08. Whereas Landsat-satellite scenes are selected on the basis of their low cloud cover, predictions could not be made for all lakes greater than 20 acres for every statewide time period because some lakes lacked a large enough remaining open-water area after the satellite-data processing.

\section{Landsat-Satellite Imagery Data-Processing Improvements}

Improvements to the satellite-data processing included how lakes are selected and how selected areas are determined. First, lakes were selected by masking known lake-polygon locations, as per the approach of Breck (2004); this ensured that all lakes greater than 20 acres had representation. Previous methods in Fuller and others (2004) did not ensure that all lakes would be selected. Second, a Normalized Difference Vegetation Index was used to remove vegetated areas, which assisted in the removal of shoreline, islands, and shallow vegetated areas within the lake-polygon locations. Third, an unsupervised classification was run to further remove shallow, vegetated, and cloud areas. Finally, the image was viewed in a band 1, 6, 6 (mapping the blue band onto band 1, and bands 6 onto the green and red bands, respectively) combination to identify haze and remove affected lakes or portions of lakes. 


\section{Comparison of the AOI Lake-Average Method and the Gethist Method}

The measured and predicted TSI (SDT) and SDT compared well between the AOI lake average and Gethist methods; however, the $\mathrm{R}^{2}$ values and also the percent of lakes predicting close to the measured values were lower for the AOI lake-average method. To allow application of the regression equation, a method from Fuller and others (2004) averaged all areas remaining in each lake after satellite-data processing, because all deep-basin locations or open-water areas are not known for all inland lakes greater than 20 acres. The AOI lake-average method lowered the percentage of lakes within 2 and 5 TSI (SDT) units or 2 and 5 SDT, in feet (table 4). This difference also can be seen in figures $4 A$ and $4 B$ with scatterplots and $\mathrm{R}^{2}$ values showing the strength of the relation between the AOI lake-average and Gethist methods. For 2003-05, the measured to predicted TSI (SDT) AOI lake-average method returned $\mathrm{R}^{2}$ values of 0.39 and 0.40 using equations 1 and 2, respectively ( 0.50 and $0.51 \mathrm{R}^{2}$ for $\left.2007-08\right)$, and the Gethist method returned $\mathrm{R}^{2}$ values of 0.71 and 0.74 using equations 1 and 2 , respectively $\left(0.77\right.$ and $0.75 \mathrm{R}^{2}$ for 2007-08). Similar comparisons were found for the measured and predicted SDT.

Fisher's Transformation was used to determine whether there was a statistically significant difference between the AOI lake-average and Gethist methods. Table 5 illustrates that for both 2003-05 and 2007-08, using either equation 1 or 2, there was a statistically significant difference at the 99-percent confidence level.

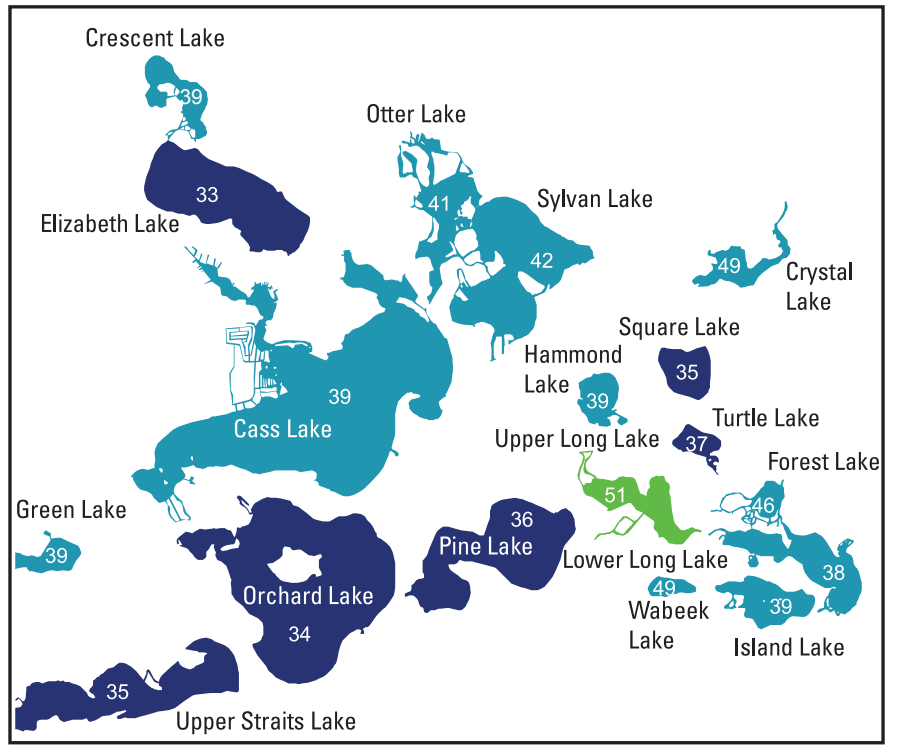

$\boldsymbol{A}$

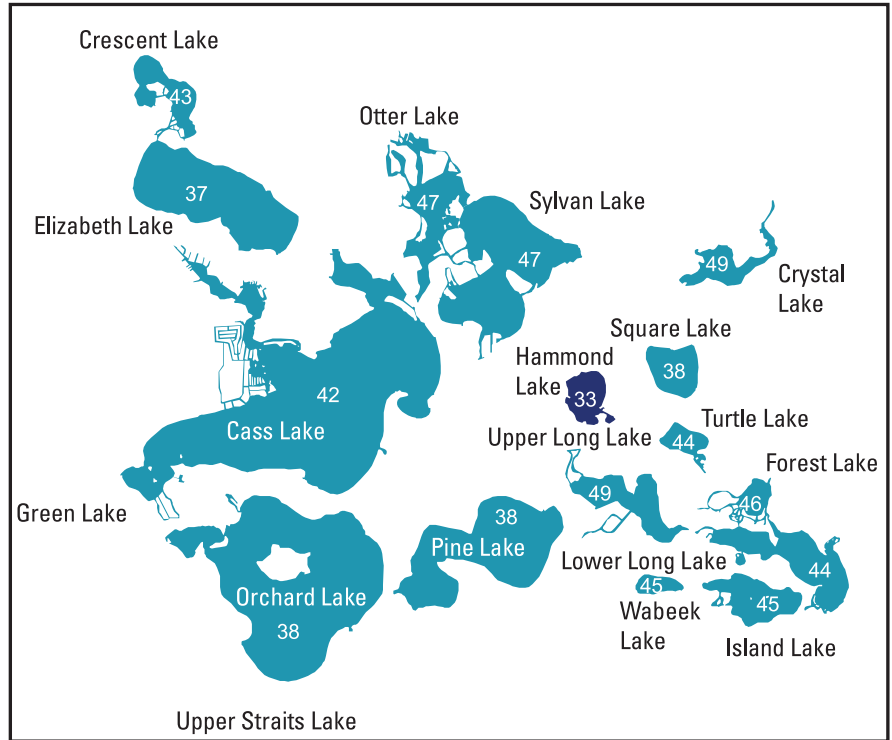

B

\section{EXPLANATION}

Trophic State Index predictions

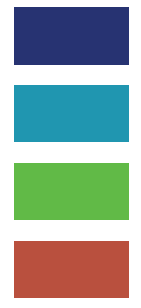

$<38$ (Oligotrophic)

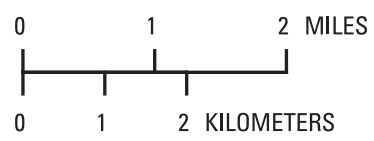

38 - 48 (Mesotrophic)

$49-61$ (Eutrophic)

$<61$ (Hypereutrophic)

Figure 6. Landsat path 20, in Oakland County, Michigan, for $\boldsymbol{A}$, Predicted Trophic State Index values for Michigan inland lakes 2003-05 and $\boldsymbol{B}$, Predicted Trophic State Index values for Michigan inland lakes 2007-08 


\section{Comparison of Equations 1 and 2}

The $\mathrm{R}^{2}$ values for the regression equations to predict TSI (SDT) and SDT for 2003-05 and 2007-08 using the Gethist method were similar for equations 1 and 2. Fisher's Transformation was used to determine whether there was a statistically significant differences between equations 1 and 2 using the Gethist method. Table 6 illustrates that there was no statistically significant difference at the 95 -percent confidence level between equations 1 and 2 using the Gethist method.

When the predicted TSI (SDT) and SDT values for the subset of lakes with measurements were plotted in a scatterplot for equations 1 and 2, the $\mathrm{R}^{2}$ value for 2003-05 was 0.95 and for 2007-08 was 0.96 . When the regression predictions were extended to all lakes greater than 20 acres with open-water areas, the $\mathrm{R}^{2}$ values decreased slightly to 0.91 for 2003-05 and 0.93 for 2007-08. Although the relation is still strong, the scatterplots in figure 5 show that equation 1 can predict higher TSI values. This discrepancy between the two predicted datasets starts around a TSI of 60 , which corresponds to the hypereutrophic category. Although the majority of lakes do not change trophic-state categories between the equations, the TSI values are different. Similarly, when comparing the predicted SDT between equations 1 and 2, equation 2 predicts higher SDT (lower TSI), starting around $20 \mathrm{ft}$ and greater, than equation 1. Whereas inland lakes with an SDT greater than $15 \mathrm{ft}$ all would be classified in the oligotrophic category, the actual TSI values from the two equations can differ.

Unfortunately, there are only 10 out of 184 measurements for 2003-05 and 12 out of 208 measurements for 2007-08 with SDT values greater than $20 \mathrm{ft}(\mathrm{TSI}<34)$ and greater than 60 TSI units (SDT $<3.5 \mathrm{ft}$ ) for 2003-05. Measurements that do fall within these ranges show no pattern for overpredicting in either range of values. The difference between the equations is beyond the range of lakes with available data.

The relation between equations 1 and 2 is strong for measured and predicted TSI (SDT) and SDT; however, for ease of comparison for predicted TSI (SDT) or SDT values between Minnesota and Wisconsin, and also for future trend analysis that might focus solely on the predicted TSI (SDT) or SDT values, equation 2 will be used for 2003-05, 2007-08, and future statewide predictions. The count and percentage for measured and predicted TSI (SDT) for equations 1 and 2 by Trophic State class can be found in table 7.
Table 5. Predicted Trophic State Index and Secchi-disk transparency results for Fisher's Transformation Significance Tests for Michigan inland lakes, 2003-05 and 2007-08.

[TSI, Trophic State index; AOI, areas of interest; $\mathrm{R}^{2}$, coefficient of determination; SDT, Secchi-disk transparency]

\begin{tabular}{|c|c|c|c|}
\hline \multicolumn{4}{|c|}{ TSI } \\
\hline & $\begin{array}{c}\text { AOI lake } \\
\text { average } R^{2}\end{array}$ & $\begin{array}{c}\text { Gethist } \\
\mathbf{R}^{2}\end{array}$ & $\begin{array}{c}\text { Fisher's } \\
\text { Transformation* }\end{array}$ \\
\hline 2003-05, Equation 1 & 0.39 & 0.71 & 4.70 \\
\hline 2003-05, Equation 2 & 0.40 & 0.74 & 5.18 \\
\hline 2007-08, Equation 1 & 0.50 & 0.77 & 4.56 \\
\hline 2007-08, Equation 2 & 0.51 & 0.75 & 3.97 \\
\hline \multicolumn{4}{|c|}{ SDT } \\
\hline & $\begin{array}{c}\text { AOI lake } \\
\text { average } R^{2}\end{array}$ & $\begin{array}{c}\text { Gethist } \\
\mathrm{R}^{2}\end{array}$ & $\begin{array}{c}\text { Fisher's } \\
\text { Transformation* }\end{array}$ \\
\hline 2003-05, Equation 1 & 0.36 & 0.70 & 4.87 \\
\hline 2003-05, Equation 2 & 0.41 & 0.67 & 3.71 \\
\hline 2007-08, Equation 1 & 0.45 & 0.73 & 4.34 \\
\hline 2007-08, Equation 2 & 0.47 & 0.72 & 3.88 \\
\hline
\end{tabular}

* Fisher's Transformation values greater than 2.576 are statistically significant at the 99-percent confidence interval.

Table 6. Comparison of Predicted Trophic State Index and Secchi-disk transparency results for equations 1 and 2 using Fisher's Transformation Significance Tests for Michigan inland lakes, 2003-05 and 2007-08.

[TSI, Trophic State index; $\mathrm{R}^{2}$, coefficient of determination; SDT, Secchidisk transparency]

\begin{tabular}{lccc}
\hline & $\begin{array}{c}\text { Equation 1 } \\
\mathbf{R}^{2}\end{array}$ & $\begin{array}{c}\text { Equation 2 } \\
\mathbf{R}^{2}\end{array}$ & $\begin{array}{c}\text { Fisher's } \\
\text { Transformation* }\end{array}$ \\
\hline 2003-05 Gethist TSI & 0.71 & 0.74 & 0.60 \\
2003-05 Gethist SDT & 0.77 & 0.75 & 0.45 \\
\hline & $\begin{array}{c}\text { Equation 1 } \\
\mathbf{R}^{2}\end{array}$ & $\begin{array}{c}\text { Equation 2 } \\
\mathbf{R}^{2}\end{array}$ & $\begin{array}{c}\text { Fisher's } \\
\text { Transformation* }\end{array}$ \\
\hline 2007-08 Gethist TSI & 0.70 & 0.67 & 0.53 \\
$2007-08$ Gethist SDT & 0.73 & 0.72 & 0.20 \\
\hline
\end{tabular}

* Fisher's Transformation values greater than 1.96 are statistically significant at the 95 -percent confidence interval. 


\section{Summary and Conclusions}

Michigan has more than 11,000 inland lakes, and their sheer number poses a physical and economical problem for collection of data needed to compute a statewide Trophic State Index (TSI). Volunteers with the Michigan Department of Natural Resources and Environment (MDNRE) Cooperative Lake Monitoring Program (CLMP) and field technicians of the U.S. Geological Survey (USGS) monitor selected lakes each year. An economical and feasible tool to expand the use of the sampling data is to relate Secchi-disk transparency (SDT) measurements to Landsat-satellite imagery with regression equations. These regression equations then can be applied to Landsat-satellite imagery to produce predicted statewide TSI (SDT) values for unmeasured open-water areas of inland lakes.

The purpose of this publication is to describe a refinement of methods originally published in Fuller and others (2004); the goal of the refinement was to produce a statewide predicted TSI for Michigan inland lakes that is more representative of the open-water area than was possible previously. The methods used in the refinement are (1) techniques used for processing Landsat-satellite imagery to identify open-water areas in lakes, (2) comparison of two methods - the area of interest (AOI) lake-average method and the Gethist method (Olmanson and others, 2001) — to return a single predicted TSI representing the open-water area of lakes, and (3) comparison of two equations from Fuller and others (2004) to equations from Olmanson and others (2001) and Kloiber and others (2002) to ascertain which equation produces predictions most reflective of measured values.

The satellite-data processing technique used to select inland lakes ensures that all inland lakes greater than 20 acres from the Michigan lake polygons shapefile (Breck, 2004) will be included unless intentionally removed during further data evaluation and processing. Running a Normalized Difference Vegetated Index on the pixels within the inland lake shapefile aided in the removal of vegetated pixels associated with shoreline, islands, or shallow water. An unsupervised classification then was run to further remove clouds and shallow water. Together, these satellite-data processing techniques did a better job than previous techniques to remove lake areas that would confound regression analysis and to better confine the dataset to unobscured open-water areas suitable for analysis.

Incorporating the Gethist image-processing method provided $\mathrm{R}^{2}$ values more comparable to the $\mathrm{R}^{2}$ values from the AOI areas used to produce the regression equations from Fuller and others (2004). Even though the Gethist areas were,

Table 7. Count and percent of measured and statewide predicted Trophic State classes for Michigan inland lakes, 2003-05 and 2007-08.

[TSI, Trophic State Index]

\begin{tabular}{|c|c|c|c|c|}
\hline \multicolumn{5}{|c|}{$2003-05$} \\
\hline & Oligotrophic & Mesotrophic & Eutrophic & Hypereutrophic \\
\hline Measured TSI count & 36 & 122 & 25 & 1 \\
\hline Statewide predicted equation 1 count & 184 & 1,979 & 759 & 199 \\
\hline Statewide predicted equation 2 count & 245 & 2,014 & 757 & 105 \\
\hline Measured TSI percent & 19.6 & 66.3 & 13.6 & 0.5 \\
\hline Statewide predicted equation 1 percent & 5.9 & 63.4 & 24.3 & 6.4 \\
\hline Statewide predicted equation 2 percent & 7.9 & 64.5 & 24.3 & 3.4 \\
\hline \multicolumn{5}{|c|}{$2007-08$} \\
\hline & Oligotrophic & Mesotrophic & Eutrophic & Hypereutrophic \\
\hline Measured TSI count & 30 & 155 & 21 & 2 \\
\hline Statewide predicted equation 1 count & 208 & 2,247 & 474 & 95 \\
\hline Statewide predicted equation 2 count & 213 & 2,242 & 499 & 70 \\
\hline Measured TSI percent & 14.4 & 74.5 & 10.1 & 1.0 \\
\hline Statewide predicted equation 1 percent & 6.9 & 74.3 & 15.7 & 3.1 \\
\hline Statewide predicted equation 2 percent & 7.0 & 74.1 & 16.5 & 2.3 \\
\hline
\end{tabular}


on average, larger than the AOI areas used previously to produce the regression equations, the Gethist method provided higher $\mathrm{R}^{2}$ values than the AOI lake-average method, which was used to apply the regression equations previously created using the AOI areas from Fuller and others (2004). The larger benefit is that the Gethist method can be applied to all lakes and does not require knowledge of the deep open-water areas, thus providing a predicted TSI (SDT) result more reflective of the deep open-water areas for unsampled inland lakes in Michigan.

Another benefit of the Gethist method is that it does not require the analyst to know the lake-measurement location. Unlike with the AOI method, measurements do not need to be removed from the analytical dataset if they do not have a corresponding latitude and longitude or if a bathymetric map is unavailable to estimate the measurement location. The Gethist method outputs the average band values for each lake in the Landsat-satellite imagery. The average band values reflect a reduced area representing the darkest values from the areas identified after satellite-data processing. The resulting average band values from the Gethist method then are related to available SDT measurements in the Landsat-satellite scenes. Predicted TSI (SDT) for inland lakes with field measurements using the Gethist method and equation 1 from Fuller and others (2004) compared well with equation 2 found in Olmanson and others (2001) and Kloiber and others (2002). There was no statistically significant difference at the 95 -percent confidence level between results from the two equations for either dataset.

Comparison of predicted TSI (SDTs) for the subset of lakes with field measurements in 2003-05 and 2007-08 resulted in $\mathrm{R}^{2}$ values of 0.95 and 0.96 , respectively. When the statewide predicted TSI (SDTs) were applied to all lakes greater than 20 acres without interference from clouds, cloud shadows, haze, or dense vegetation using equations 1 and 2 , the $\mathrm{R}^{2}$ values were 0.91 for $2003-05$ and 0.93 for $2007-08$. Although this is still a strong relation indicating minimal differences in results, equation 1 nevertheless predicts higher than equation 2 for TSI values greater than $60(\mathrm{SDT}<3.5 \mathrm{ft})$ and lower for SDT values greater than $20 \mathrm{ft}($ TSI $<34)$. The few measurements available in these high and low ranges did not reflect the pattern for overpredicting and underpredicting, and measurements were not available at the far extremes on either side to provide insight. Although the lakes still predicted to the correct trophic state category, the predicted TSI (SDT) and SDT values were different at the extreme ends of the TSI scale. For ease of comparison between Minnesota and Wisconsin statewide predictions, and also for future trend analysis that might focus solely on the predicted TSI (SDT) or SDT values, equation 2 is planned to be used for 2003-05 and 2007-08 and future statewide predictions.

\section{References Cited}

Baban, S.M.J., 1993, Detecting water quality parameters in the Norfolk Broads, UK, using Landsat imagery: International Journal of Remote Sensing, v. 14, no. 7, p. 1,247-1,267.

Breck, James, 2004, Michigan lake polygons: Michigan Department of Natural Resources and Environment, Fisheries Division, Institute for Fisheries Research, accessed December 2008 at http://www.mcgi.state.mi.us/mgdl/?rel=t hext\&action $=$ thmname $\&$ cid $=3 \&$ cat $=$ Lake + Polygons .

Canfield, D.E., Jr., Brown, C.D., Bachmann, R.W., and Hoyer, M.V., 2002, Volunteer lake monitoring-Testing the reliability of data collected by the Florida LAKEWATCH Program: Lake and Reservoir Management, v. 18, no. 1, p. 1-9.

Carlson, R.E., 1977, A trophic state index for lakes: Limnology and Oceanography, v. 22, p. 361-369.

Chipman, J.W., Lillesand, T.M., Schmaltz, J.E., Leale, J.E., and Nordheim, M.J., 2004, Mapping lake water clarity with Landsat images in Wisconsin, USA: Canada Journal of Remote Sensing, v. 30, p. 1-7.

Dekker, A.G., and Peters, S.W.M., 1993, The use of the Thematic Mapper for the analysis of eutrophic lakes - A case study in the Netherlands: International Journal of Remote Sensing, v. 4, no. 5, p. 799-821.

Fuller, L.M, Aichele, S.S., and Minnerick, R.J., 2004, Predicting water quality by relating Secchi-disk transparency and chlorophyll $a$ measurements to satellite imagery for Michigan inland lakes, August 2002: U.S. Geological Survey Scientific Investigations Report 2004-5086, 44 p. (also available at http://pubs.usgs.gov/sir/2004/5086/).

Fuller, L.M., and Minnerick, R.J., 2007, Predicting water quality by relating Secchi-disk transparency and chlorophyll a measurements to Landsat satellite imagery for Michigan inland lakes, 2001-06: U.S. Geological Survey Fact Sheet 2007-3022, 4 p., available online at http://pubs.usgs.gov/ $f_{s} / 2007 / 3022 /$.

Fuller, L.M., and Minnerick, R.J., 2008, State and regional water-quality characteristics and trophic conditions of Michigan's inland lakes, 2001-2005: U.S. Geological Survey Scientific Investigations Report 2008-5188, 58 p. (also available at http://pubs.water.usgs.gov/sir20085188/). 
Giardino, Claudia; Pepe, Monica; Brivio, P.A.; Ghezzi, Paolo; and Zilioli, Eugenio, 2001, Detecting chlorophyll, Secchi disk depth and surface temperature in a sub-alpine lake using Landsat imagery: Science of the Total Environment, v. 268, p. 19-29.

Jensen, J.R., 2007, Remote sensing of the environmentAn earth resource perspective ( 2 d ed.): Upper Saddle River, N.J., Prentice Hall, p. 383-386.

Kloiber, S.M., Anderle, T.H., Brezonik, P.L., Olmanson, L., Bauer, M.E., and Brown, D.A., 2000, Trophic state assessment of lakes in the Twin Cities (Minnesota, USA) region by satellite imagery: Archive Hydrobiologie Special Issues, Advances in Limnology, v. 55, p. 137-151.

Kloiber, S.M., Brezonik, P.L., Olmanson, L.G., and Bauer, M.E., 2002, A procedure for regional lake water clarity assessment using Landsat multispectral data: Remote Sensing of Environment, v. 82, no. 1, p. 38-47.

Krysel, Charles; Boyer, E.M.; Parson, Charles; and Welle, Patrick, 2003, Lakeshore property values and water quality_Evidence from property sales in the Mississippi Headwaters Region [abs.]: Accessed June 2010 at http://www.uwsp.edu/cnr/uwexlakes/economicsOfWater/ documents/76_mSPropertySales_krysel_abstr.pdf.

Kutser, Tiit; Metsamaa, Liisa; Strömbeck, Niklas; and Vahtmäe, Ele, 2006, Monitoring cyanobacterial blooms by satellite remote sensing: Estuarine, Coastal and Shelf Science, v. 67, p. 303-312.

Mayo, M., Gitelson A., Yacobi, Y.Z., and Ben-Avraham, Z., 1995, Chlorophyll distribution in Lake Kinneret determined from Landsat Thematic Mapper data: International Journal of Remote Sensing, v. 16, no. 1, p. 175-182.

National Aeronautics Space Administration, 2003, Landsat 7 science data user's handbook - Chapter 11, Data products: Accessed June 2010 at http://landsathandbook.gsfc.nasa. gov/handbook/handbook_htmls/chapter11/chapter11.html.

Nelson, S.A.C., Soranno, P.A., Cheruvelil, K.S., Batzli, S.A., and Skole, D.L., 2003, Regional assessment of lake water clarity using satellite remote sensing: Journal of Limnology, v. 62 , supp. 1, p. 27-32.
Obrecht, D.V.; Milanick, Margaret; Perkins, B.D., Ready, Diana; and Jones, J.R., 1998, Evaluation of data generated from lake samples collected by volunteers: Lake and Reservoir Management, v. 14, no. 1, p. 21-27.

Olmanson, L.G., Bauer, M.E., and Brezonik, P.L., 2008, A 20-year Landsat water clarity census of Minnesota's 10,000 lakes: Remote Sensing of Environment, v. 112, no. 11, p. 4,086-4,097.

Olmanson, L.G., Kloiber, S.M., Bauer, M.E., and Brezonik, P.L., 2001, Image processing protocol for regional assessments of lake water quality: St. Paul, Minn., University of Minnesota, Water Resources Center and Remote Sensing Laboratory, p. 1-13.

Peckham, S.D., and Lillesand, T.M., 2006, Detection of spatial and temporal trends in Wisconsin lake water clarity using Landsat-derived estimates of Secchi depth: Lake and Reservoir Management, v. 22, no. 4, p. 331-341.

Stynes, D.J., 2002, Michigan statewide tourism spending and economic impact estimates 1998-2000: Accessed November 2003 at http://web4.canr.msu.edu/mgm2/econ/miteim/ MichiganSatExec.pdf.

U.S. Environmental Protection Agency, 2007, Aquatic biodiversity-Carlson's Trophic State Index: Accessed June 2010 at http://www.epa.gov/bioindicators/aquatic/carlson.html.

Wiangwang, Narumon, 2002, Water clarity/trophic condition monitoring by using satellite remote sensing data: East Lansing, Mich., Michigan State University, Department of Geography Graduate Program, Master's thesis, $152 \mathrm{p}$.

Yamane, Taro, 1973, Statistics-An introductory analysis (3d ed): New York, Harper \& Row, p. 493-498.

Zilioli, E., and Brivio, P.A., 1997, The satellite derived optical information for the comparative assessment of lacustrine water quality: Science of the Total Environment, v. 196, p. 229-245. 


\section{Appendixes 1 and 2}

Appendix 1. Results and computations by Landsat-satellite path for Michigan inland lakes, 2003-05, of measured and predicted Secchi-disk transparency and Trophic State Index values for the area of interest, area of interest lake-average method, and the Gethist method...

Appendix 2. Results and computations by Landsat-satellite path for Michigan inland lakes, 2007-08, of measured and predicted Secchi-disk transparency and Trophic State Index values for the area of interest, area of interest lake-average method, and the Gethist method.. 
Appendix 1. Results and computations by Landsat-satellite path for Michigan inland lakes, 2003-05, of measured and predicted Secchi-disk transparency and Trophic State Index values for the area of interest, area of interest lake-average method, and the Gethist method.

[SDT, Secchi-disk transparency; AOI, area of interest; TSI, Trophic State Index; Eq, equation; ${ }^{\text {, }}$ measurement not used owing to issue with placement]

\begin{tabular}{|c|c|c|c|c|c|c|c|c|c|c|c|c|c|c|}
\hline \multicolumn{2}{|c|}{ Landsat satellite } & \multirow[b]{2}{*}{ Lake Name } & \multirow[b]{2}{*}{ County } & \multirow[b]{2}{*}{ Acres } & \multicolumn{4}{|c|}{ Measured SDT } & \multicolumn{2}{|c|}{ AOI TSI } & \multicolumn{2}{|c|}{$\begin{array}{c}\text { AOI lake average } \\
\text { TSI }\end{array}$} & \multicolumn{2}{|c|}{ Gethist TSI } \\
\hline Path & Row & & & & Sampled & SDT ft & SDT m & TSI & Eq1 & Eq2 & Eq1 & Eq2 & Eq1 & $\mathrm{Eq} 2$ \\
\hline 20 & $30-31$ & Round Lake & Clinton & 87 & 2004-09-25 & 5.5 & 1.7 & 53 & 51 & 48 & 53 & 51 & 52 & 49 \\
\hline 20 & $30-31$ & Byram Lake & Genesee & 134 & 2004-09-19 & 12.0 & 3.7 & 41 & 42 & 44 & 48 & 48 & 43 & 44 \\
\hline 20 & $30-31$ & Fenton Lake & Genesee & 866 & 2004-09-19 & 15.5 & 4.7 & 38 & 34 & 32 & 44 & 43 & 38 & 37 \\
\hline 20 & $30-31$ & Ponemah Lake & Genesee & 410 & 2004-09-25 & 12.5 & 3.8 & 41 & 41 & 41 & 45 & 44 & 42 & 41 \\
\hline 20 & $30-31$ & Silver Lake & Genesee & 339 & 2004-09-26 & 15.0 & 4.6 & 38 & 40 & 40 & 43 & 44 & 39 & 40 \\
\hline 20 & $30-31$ & Clear Lake & Jackson & 129 & 2004-09-21 & 11.5 & 3.5 & 42 & 44 & 44 & 48 & 47 & 41 & 42 \\
\hline 20 & $30-31$ & Gilletts Lake & Jackson & 334 & 2004-09-16 & 7.5 & 2.3 & 48 & 43 & 43 & 61 & 58 & 52 & 51 \\
\hline 20 & $30-31$ & Grass Lake & Jackson & 353 & 2004-09-18 & 5.0 & 1.5 & 54 & * & * & $*$ & $*$ & 49 & 50 \\
\hline 20 & $30-31$ & Vineyard Lake & Jackson & 541 & 2004-09-21 & 14.0 & 4.3 & 39 & 37 & 38 & 46 & 45 & 38 & 38 \\
\hline 20 & $30-31$ & Nepessing Lake & Lapeer & 427 & 2004-09-23 & 17.0 & 5.2 & 36 & 38 & 38 & 43 & 43 & 39 & 39 \\
\hline 20 & $30-31$ & Evans Lake & Lenawee & 215 & 2004-09-22 & 24.0 & 7.3 & 31 & 37 & 36 & 39 & 37 & 32 & 30 \\
\hline 20 & $30-31$ & East Crooked Lake & Livingston & 248 & 2004-09-20 & 19.0 & 5.8 & 35 & 41 & 42 & 46 & 46 & 39 & 40 \\
\hline 20 & $30-31$ & Gut Lake & Livingston & 32 & 2004-09-20 & 13.0 & 4.0 & 40 & 40 & 40 & 38 & 38 & 34 & 34 \\
\hline 20 & $30-31$ & Hamburg Lake & Livingston & 99 & 2004-09-21 & 17.0 & 5.2 & 36 & 36 & 37 & 41 & 40 & 36 & 36 \\
\hline 20 & $30-31$ & Oneida Lake & Livingston & 46 & 2004-09-19 & 10.0 & 3.0 & 44 & 43 & 43 & 49 & 47 & 43 & 41 \\
\hline 20 & $30-31$ & Strawberry Lake & Livingston & 261 & 2004-09-24 & 9.0 & 2.7 & 45 & 44 & 43 & 46 & 45 & 42 & 41 \\
\hline 20 & $30-31$ & West Crooked Lake & Livingston & 191 & 2004-09-19 & 8.5 & 2.6 & 46 & 41 & 43 & 47 & 47 & 42 & 43 \\
\hline 20 & $30-31$ & Buckhorn Lake & Oakland & 43 & 2004-09-25 & 13.0 & 4.0 & 40 & 44 & 42 & 50 & 48 & 44 & 43 \\
\hline 20 & $30-31$ & Taylor Lake & Oakland & 39 & 2004-09-25 & 20.0 & 6.1 & 34 & $*$ & $*$ & $*$ & $*$ & 37 & 39 \\
\hline 20 & $30-31$ & Leisure Lake & Shiawassee & 45 & 2004-09-22 & 5.0 & 1.5 & 54 & 55 & 54 & 55 & 53 & 52 & 50 \\
\hline 20 & $30-31$ & Pleasant Lake & Washtenaw & 193 & 2004-09-22 & 10.0 & 3.0 & 44 & 43 & 45 & 47 & 48 & 44 & 45 \\
\hline 20 & $30-31$ & Portage Lake & Washtenaw & 641 & 2004-09-19 & 10.0 & 3.0 & 44 & 41 & 42 & 52 & 51 & 46 & 47 \\
\hline 21 & $28-31$ & Hubbard Lake & Alcona & 8768 & 2004-09-13 & 14.0 & 4.3 & 39 & 37 & 36 & 40 & 38 & 36 & 35 \\
\hline
\end{tabular}


Appendix 1. Results and computations by Landsat-satellite path for Michigan inland lakes, 2003-05, of measured and predicted Secchi-disk transparency and Trophic State Index values for the area of interest, area of interest lake-average method, and the Gethist method.-Continued

[SDT, Secchi-disk transparency; AOI, area of interest; TSI, Trophic State Index; Eq, equation; * , measurement not used owing to issue with placement]

\begin{tabular}{|c|c|c|c|c|c|c|c|c|c|c|c|c|c|c|}
\hline \multicolumn{2}{|c|}{ Landsat satellite } & \multirow[b]{2}{*}{ Lake Name } & \multirow[b]{2}{*}{ County } & \multirow[b]{2}{*}{ Acres } & \multicolumn{4}{|c|}{ Measured SDT } & \multicolumn{2}{|c|}{ AOI TSI } & \multicolumn{2}{|c|}{$\begin{array}{c}\text { AOI lake average } \\
\text { TSI }\end{array}$} & \multicolumn{2}{|c|}{ Gethist TSI } \\
\hline Path & Row & & & & Sampled & SDT ft & SDT m & TSI & Eq1 & Eq2 & Eq1 & $\mathrm{Eq} 2$ & Eq1 & $\mathrm{Eq} 2$ \\
\hline 21 & $28-31$ & Jewell Lake & Alcona & 184 & 2004-09-12 & 8.5 & 2.6 & 46 & 43 & 43 & 53 & 51 & 47 & 47 \\
\hline 21 & $28-31$ & Bellaire Lake & Antrim & 1789 & 2004-09-14 & 16.0 & 4.9 & 37 & 34 & 34 & 40 & 39 & 34 & 34 \\
\hline 21 & $28-31$ & Clam Lake & Antrim & 438 & 2004-09-15 & 21.0 & 6.4 & 33 & 33 & 32 & 40 & 39 & 35 & 35 \\
\hline 21 & $28-31$ & Barlow Lake & Barry & 181 & 2004-09-15 & 7.5 & 2.3 & 48 & 42 & 42 & 46 & 45 & 41 & 42 \\
\hline 21 & $28-31$ & Randall N Cemetary L & Branch & 511 & 2004-09-16 & 7.5 & 2.3 & 48 & 47 & 47 & 48 & 48 & 47 & 48 \\
\hline 21 & $28-31$ & Birch Lake & Cass & 282 & 2004-09-13 & 12.0 & 3.7 & 41 & 45 & 44 & 46 & 45 & 44 & 43 \\
\hline 21 & $28-31$ & Christiana & Cass & 560 & 2004-09-14 & 6.5 & 2.0 & 50 & 47 & 47 & 48 & 48 & 47 & 48 \\
\hline 21 & $28-31$ & Diamond Lake & Cass & 1041 & 2004-09-14 & 12.0 & 3.7 & 41 & 43 & 43 & 47 & 45 & 44 & 43 \\
\hline 21 & $28-31$ & Juno & Cass & 560 & 2004-09-14 & 6.5 & 2.0 & 50 & 48 & 48 & 48 & 48 & 47 & 48 \\
\hline 21 & $28-31$ & Magician Lake & Cass & 522 & 2004-09-15 & 7.0 & 2.1 & 49 & 45 & 45 & 50 & 48 & 48 & 47 \\
\hline 21 & $28-31$ & Painter & Cass & 560 & 2004-09-14 & 5.5 & 1.7 & 53 & 48 & 48 & 48 & 48 & 47 & 48 \\
\hline 21 & $28-31$ & Shavehead Lake & Cass & 299 & 2004-09-19 & 8.0 & 2.4 & 47 & 45 & 43 & 48 & 45 & 45 & 44 \\
\hline 21 & $28-31$ & Twin Lake (north) & Cass & 61 & 2004-09-11 & 12.5 & 3.8 & 41 & 46 & 46 & 49 & 48 & 46 & 47 \\
\hline 21 & $28-31$ & Twin Lake (south) & Cass & 43 & 2004-09-12 & 7.0 & 2.1 & 49 & 45 & 45 & 51 & 48 & 47 & 46 \\
\hline 21 & $28-31$ & Shingle Lake & Clare & 30 & 2004-09-14 & 11.0 & 3.4 & 43 & 40 & 40 & 40 & 39 & 38 & 38 \\
\hline 21 & $28-31$ & Windover Lake & Clare & 68 & 2004-09-13 & 21.0 & 6.4 & 33 & 35 & 34 & 43 & 42 & 36 & 35 \\
\hline 21 & $28-31$ & Round Lake & Clinton & 87 & 2004-09-12 & 6.0 & 1.8 & 51 & 46 & 47 & 48 & 49 & 47 & 48 \\
\hline 21 & $28-31$ & Byram Lake & Genesee & 134 & 2004-09-19 & 12.0 & 3.7 & 41 & 46 & 46 & 46 & 45 & 44 & 44 \\
\hline 21 & $28-31$ & Fenton Lake & Genesee & 866 & 2004-09-11 & 16.0 & 4.9 & 37 & 37 & 37 & 43 & 43 & 40 & 40 \\
\hline 21 & $28-31$ & Ponemah Lake & Genesee & 410 & 2004-09-10 & 11.5 & 3.5 & 42 & 42 & 42 & 42 & 42 & 41 & 41 \\
\hline 21 & $28-31$ & Silver Lake & Genesee & 339 & 2004-09-12 & 12.5 & 3.8 & 41 & 42 & 41 & 44 & 43 & 40 & 40 \\
\hline 21 & $28-31$ & Lake Twenty & Gladwin & 124 & 2004-09-08 & 9.5 & 2.9 & 45 & 38 & 37 & 43 & 43 & 41 & 41 \\
\hline 21 & $28-31$ & Crystal Lake & Hillsdale & 130 & 2004-09-15 & 14.0 & 4.3 & 39 & 44 & 45 & 44 & 44 & 43 & 43 \\
\hline
\end{tabular}


Appendix 1. Results and computations by Landsat-satellite path for Michigan inland lakes, 2003-05, of measured and predicted Secchi-disk transparency and Trophic State Index values for the area of interest, area of interest lake-average method, and the Gethist method.-Continued

[SDT, Secchi-disk transparency; AOI, area of interest; TSI, Trophic State Index; Eq, equation; *, measurement not used owing to issue with placement]

\begin{tabular}{|c|c|c|c|c|c|c|c|c|c|c|c|c|c|c|}
\hline \multicolumn{2}{|c|}{ Landsat satellite } & \multirow[b]{2}{*}{ Lake Name } & \multirow[b]{2}{*}{ County } & \multirow[b]{2}{*}{ Acres } & \multicolumn{4}{|c|}{ Measured SDT } & \multicolumn{2}{|c|}{ AOI TSI } & \multicolumn{2}{|c|}{$\begin{array}{c}\text { AOI lake average } \\
\text { TSI }\end{array}$} & \multicolumn{2}{|c|}{ Gethist TSI } \\
\hline Path & Row & & & & Sampled & SDT ft & SDT m & TSI & Eq1 & $\mathrm{Eq} 2$ & Eq1 & $\mathrm{Eq} 2$ & Eq1 & $\mathrm{Eq} 2$ \\
\hline 21 & $28-31$ & Perch Lake & Hillsdale & 46 & 2004-09-16 & 8.0 & 2.4 & 47 & 46 & 46 & 45 & 46 & 45 & 45 \\
\hline 21 & $28-31$ & Cedar Lake & Iosco & 142 & 2004-09-13 & 8.5 & 2.6 & 46 & * & * & $*$ & $*$ & 50 & 50 \\
\hline 21 & $28-31$ & Van Etten Lake & Iosco & 1409 & 2004-09-10 & 7.5 & 2.3 & 48 & 48 & 48 & 45 & 46 & 45 & 46 \\
\hline 21 & $28-31$ & Gilletts Lake & Jackson & 334 & 2004-09-16 & 7.5 & 2.3 & 48 & $*$ & $*$ & * & * & 51 & 50 \\
\hline 21 & $28-31$ & Grass Lake & Jackson & 353 & 2004-09-18 & 5.0 & 1.5 & 54 & 49 & 50 & 49 & 49 & 49 & 49 \\
\hline 21 & $28-31$ & Portage Lake & Jackson & 398 & 2004-09-18 & 11.0 & 3.4 & 43 & 45 & 45 & 51 & 49 & 48 & 48 \\
\hline 21 & $28-31$ & Vineyard Lake & Jackson & 541 & 2004-09-09 & 10.0 & 3.0 & 44 & 46 & 46 & 53 & 51 & 49 & 48 \\
\hline 21 & $28-31$ & Indian Lake & Kalamazoo & 788 & 2004-09-13 & 6.0 & 1.8 & 51 & 51 & 49 & 53 & 50 & 52 & 49 \\
\hline 21 & $28-31$ & Bear Lake & Kalkaska & 313 & 2004-09-16 & 28.0 & 8.5 & 29 & 32 & 29 & 37 & 34 & 34 & 32 \\
\hline 21 & $28-31$ & Cub Lake & Kalkaska & 57 & 2004-09-10 & 24.0 & 7.3 & 31 & 36 & 35 & 40 & 39 & 37 & 36 \\
\hline 21 & $28-31$ & Bostwick Lake & Kent & 213 & 2004-09-17 & 6.5 & 2.0 & 50 & 43 & 44 & 46 & 47 & 45 & 46 \\
\hline 21 & $28-31$ & Freska Lake & Kent & 59 & 2004-09-16 & 8.0 & 2.4 & 47 & * & * & * & * & 45 & 46 \\
\hline 21 & $28-31$ & Murray Lake & Kent & 312 & 2004-09-16 & 11.0 & 3.4 & 43 & 44 & 44 & 45 & 45 & 43 & 44 \\
\hline 21 & $28-31$ & East Crooked Lake & Livingston & 248 & 2004-09-13 & 16.0 & 4.9 & 37 & 40 & 40 & 45 & 45 & 42 & 42 \\
\hline 21 & $28-31$ & Gut Lake & Livingston & 32 & 2004-09-11 & 13.0 & 4.0 & 40 & 40 & 41 & 42 & 42 & 40 & 41 \\
\hline 21 & $28-31$ & Oneida Lake & Livingston & 46 & 2004-09-12 & 10.5 & 3.2 & 43 & 42 & 43 & 44 & 45 & 42 & 43 \\
\hline 21 & $28-31$ & Strawberry Lake & Livingston & 261 & 2004-09-11 & 8.0 & 2.4 & 47 & 45 & 46 & 45 & 45 & 43 & 44 \\
\hline 21 & $28-31$ & West Crooked Lake & Livingston & 191 & 2004-09-12 & 7.5 & 2.3 & 48 & 46 & 47 & 47 & 47 & 45 & 46 \\
\hline 21 & $28-31$ & Horsehead Lake & Mecosta & 443 & 2004-09-15 & 12.0 & 3.7 & 41 & 43 & 44 & 46 & 45 & 40 & 41 \\
\hline 21 & $28-31$ & Mecosta Lake & Mecosta & 312 & 2004-09-07 & 9.0 & 2.7 & 45 & 43 & 43 & 46 & 46 & 45 & 45 \\
\hline 21 & $28-31$ & Pretty Lake & Mecosta & 116 & 2004-09-19 & 11.0 & 3.4 & 43 & 40 & 40 & 41 & 42 & 39 & 40 \\
\hline 21 & $28-31$ & Round Lake & Mecosta & 157 & 2004-09-18 & 14.0 & 4.3 & 39 & 43 & 45 & 42 & 43 & 41 & 42 \\
\hline 21 & $28-31$ & West Canadian Lake & Mescoda & 133 & 2004-09-10 & 12.0 & 3.7 & 41 & 39 & 40 & 43 & 44 & 41 & 42 \\
\hline
\end{tabular}


Appendix 1. Results and computations by Landsat-satellite path for Michigan inland lakes, 2003-05, of measured and predicted Secchi-disk transparency and Trophic State Index values for the area of interest, area of interest lake-average method, and the Gethist method.-Continued

[SDT, Secchi-disk transparency; AOI, area of interest; TSI, Trophic State Index; Eq, equation; * measurement not used owing to issue with placement]

\begin{tabular}{|c|c|c|c|c|c|c|c|c|c|c|c|c|c|c|}
\hline \multicolumn{2}{|c|}{ Landsat satellite } & \multirow[b]{2}{*}{ Lake Name } & \multirow[b]{2}{*}{ County } & \multirow[b]{2}{*}{ Acres } & \multicolumn{4}{|c|}{ Measured SDT } & \multicolumn{2}{|c|}{ AOI TSI } & \multicolumn{2}{|c|}{$\begin{array}{c}\text { AOI lake average } \\
\text { TSI }\end{array}$} & \multicolumn{2}{|c|}{ Gethist TSI } \\
\hline Path & Row & & & & Sampled & SDT ft & SDT $m$ & TSI & Eq1 & Eq2 & Eq1 & $\mathrm{Eq2}$ & Eq1 & Eq2 \\
\hline 21 & $28-31$ & Sanford Lake & Midland & 1402 & 2004-09-11 & 9.0 & 2.7 & 45 & 39 & 39 & 42 & 42 & 40 & 40 \\
\hline 21 & $28-31$ & Baldwin Lake & Montcalm & 62 & 2004-09-18 & 9.5 & 2.9 & 45 & 41 & 42 & 43 & 44 & 42 & 43 \\
\hline 21 & $28-31$ & Clifford Lake & Montcalm & 195 & 2004-09-15 & 11.0 & 3.4 & 43 & 44 & 45 & 44 & 45 & 43 & 44 \\
\hline 21 & $28-31$ & Derby Lake & Montcalm & 114 & 2004-09-15 & 19.0 & 5.8 & 35 & 40 & 41 & 43 & 43 & 40 & 41 \\
\hline 21 & $28-31$ & Muskellunge Lake & Montcalm & 137 & 2004-09-10 & 11.0 & 3.4 & 43 & 42 & 43 & 44 & 45 & 42 & 43 \\
\hline 21 & $28-31$ & Picnic Lake & Montcalm & 23 & 2004-09-07 & 2.5 & 0.8 & 64 & 60 & 55 & 61 & 55 & 61 & 56 \\
\hline 21 & $28-31$ & Avalon Lake & Montmorency & 386 & 2004-09-15 & 27.0 & 8.2 & 30 & 31 & 29 & 33 & 30 & 30 & 27 \\
\hline 21 & $28-31$ & Bills Lake & Newaygo & 200 & 2004-09-16 & 10.0 & 3.0 & 44 & 41 & 42 & 44 & 43 & 40 & 40 \\
\hline 21 & $28-31$ & Sylvan Lake & Newaygo & 102 & 2004-09-16 & 10.0 & 3.0 & 44 & 40 & 42 & 43 & 43 & 40 & 41 \\
\hline 21 & $28-31$ & Island Lake & Ogemaw & 60 & 2004-09-13 & 15.0 & 4.6 & 38 & 43 & 44 & 45 & 45 & 42 & 43 \\
\hline 21 & $28-31$ & Center Lake & Osceola & 41 & 2004-09-12 & 17.0 & 5.2 & 36 & 37 & 38 & 37 & 37 & 36 & 36 \\
\hline 21 & $28-31$ & Hicks Lake & Osceola & 160 & 2004-09-09 & 3.5 & 1.1 & 59 & 59 & 55 & 56 & 53 & 57 & 55 \\
\hline 21 & 28-31 & Wells Lake & Osceola & 48 & 2004-09-15 & 18.0 & 5.5 & 35 & 39 & 40 & 41 & 42 & 40 & 41 \\
\hline 21 & $28-31$ & Big Bradford Lake & Otsego & 256 & 2004-09-06 & 17.0 & 5.2 & 36 & 39 & 38 & 39 & 38 & 35 & 34 \\
\hline 21 & $28-31$ & Big Lake & Otsego & 124 & 2004-09-10 & 19.0 & 5.8 & 35 & 36 & 36 & 38 & 38 & 37 & 36 \\
\hline 21 & $28-31$ & Viking Lake & Otsego & 36 & 2004-09-12 & 6.0 & 1.8 & 51 & 53 & 51 & 52 & 50 & 53 & 52 \\
\hline 21 & $28-31$ & Corey Lake & St. Joseph & 599 & 2004-09-16 & 8.0 & 2.4 & 47 & 43 & 44 & 48 & 46 & 45 & 44 \\
\hline 21 & $28-31$ & Fishers Lake & St. Joseph & 330 & 2004-09-11 & 10.0 & 3.0 & 44 & 48 & 47 & 49 & 47 & 45 & 45 \\
\hline 21 & $28-31$ & Fishers Lake & St. Joseph & 330 & 2004-09-11 & 10.0 & 3.0 & 44 & 47 & 47 & 49 & 47 & 45 & 45 \\
\hline 21 & $28-31$ & Klinger Lake & St. Joseph & 835 & 2004-09-15 & 11.0 & 3.4 & 43 & 46 & 45 & 47 & 46 & 45 & 45 \\
\hline 21 & $28-31$ & Pleasant Lake & St. Joseph & 256 & 2004-09-15 & 13.0 & 4.0 & 40 & 44 & 45 & 49 & 48 & 45 & 45 \\
\hline 21 & $28-31$ & Cedar Lake & Van Buren & 275 & 2004-09-10 & 13.5 & 4.1 & 40 & 43 & 44 & 47 & 47 & 44 & 45 \\
\hline 21 & $28-31$ & Crooked Lake & Van Buren & 117 & 2004-09-05 & 12.0 & 3.7 & 41 & 46 & 47 & 46 & 46 & 44 & 45 \\
\hline
\end{tabular}


Appendix 1. Results and computations by Landsat-satellite path for Michigan inland lakes, 2003-05, of measured and predicted Secchi-disk transparency and Trophic State Index values for the area of interest, area of interest lake-average method, and the Gethist method.-Continued

[SDT, Secchi-disk transparency; AOI, area of interest; TSI, Trophic State Index; Eq, equation; *, measurement not used owing to issue with placement]

\begin{tabular}{|c|c|c|c|c|c|c|c|c|c|c|c|c|c|c|}
\hline \multicolumn{2}{|c|}{ Landsat satellite } & \multirow[b]{2}{*}{ Lake Name } & \multirow[b]{2}{*}{ County } & \multirow[b]{2}{*}{ Acres } & \multicolumn{4}{|c|}{ Measured SDT } & \multicolumn{2}{|c|}{ AOI TSI } & \multicolumn{2}{|c|}{$\begin{array}{c}\text { AOI lake average } \\
\text { TSI }\end{array}$} & \multicolumn{2}{|c|}{ Gethist TSI } \\
\hline Path & Row & & & & Sampled & SDT ft & SDT m & TSI & Eq1 & $\mathrm{Eq} 2$ & Eq1 & $\mathrm{Eq} 2$ & Eq1 & $\mathrm{Eq} 2$ \\
\hline 21 & $28-31$ & Crooked Lake Little & Van Buren & 114 & 2004-09-14 & 14.0 & 4.3 & 39 & 45 & 46 & 45 & 46 & 44 & 45 \\
\hline 21 & $28-31$ & Silver Lake & Van Buren & 50 & 2004-09-13 & 12.5 & 3.8 & 41 & 41 & 43 & 43 & 45 & 42 & 44 \\
\hline 21 & $28-31$ & Pleasant Lake & Washtenaw & 193 & 2004-09-16 & 10.5 & 3.2 & 43 & 48 & 48 & 47 & 47 & 47 & 47 \\
\hline 21 & $28-31$ & Portage Lake & Washtenaw & 641 & 2004-09-12 & 9.5 & 2.9 & 45 & 48 & 48 & 50 & 50 & 49 & 49 \\
\hline 21 & $28-31$ & Stone Ledge Lake & Wexford & 83 & 2004-09-18 & 13.0 & 4.0 & 40 & 38 & 37 & 39 & 39 & 36 & 35 \\
\hline 22 & $28-31$ & Goshorn Lake & Allegan & 28 & 2004-09-18 & 6.5 & 2.0 & 50 & 48 & 47 & 48 & 47 & 48 & 46 \\
\hline 22 & $28-31$ & Hutchins Lake & Allegan & 379 & 2004-09-17 & 8.0 & 2.4 & 47 & 42 & 43 & 50 & 49 & 45 & 45 \\
\hline 22 & $28-31$ & Torch Lake & Antrim & 18722 & 2004-09-23 & 16.5 & 5.0 & 37 & 38 & 38 & 39 & 39 & 37 & 36 \\
\hline 22 & $28-31$ & Ann Lake & Benzie & 501 & 2004-09-17 & 13.0 & 4.0 & 40 & 42 & 43 & 47 & 46 & 43 & 43 \\
\hline 22 & $28-31$ & Crystal Lake & Benzie & 9869 & 2004-09-26 & 18.0 & 5.5 & 35 & 36 & 33 & 37 & 35 & 35 & 32 \\
\hline 22 & $28-31$ & Christiana & Cass & 560 & 2004-09-22 & 7.5 & 2.3 & 48 & 48 & 47 & 48 & 47 & 46 & 46 \\
\hline 22 & $28-31$ & Diamond Lake & Cass & 1041 & 2004-09-23 & 12.0 & 3.7 & 41 & 40 & 41 & 49 & 48 & 43 & 45 \\
\hline 22 & $28-31$ & Juno & Cass & 560 & 2004-09-22 & 7.0 & 2.1 & 49 & 44 & 44 & 47 & 46 & 46 & 46 \\
\hline 22 & $28-31$ & Painter & Cass & 560 & 2004-09-22 & 6.5 & 2.0 & 50 & 47 & 47 & 47 & 46 & 46 & 46 \\
\hline 22 & $28-31$ & Shavehead Lake & Cass & 299 & 2004-09-19 & 8.0 & 2.4 & 47 & 49 & 50 & 51 & 51 & 50 & 51 \\
\hline 22 & $28-31$ & Twin Lake (north) & Cass & 61 & 2004-09-19 & 18.0 & 5.5 & 35 & 41 & 41 & 46 & 44 & 41 & 40 \\
\hline 22 & $28-31$ & Twin Lake (south) & Cass & 43 & 2004-09-23 & 10.0 & 3.0 & 44 & 41 & 41 & 54 & 51 & 43 & 44 \\
\hline 22 & $28-31$ & Lily Lake & Clare & 190 & 2004-09-24 & 9.5 & 2.9 & 45 & 42 & 42 & 42 & 42 & 41 & 41 \\
\hline 22 & $28-31$ & Shingle Lake & Clare & 30 & 2004-09-22 & 13.0 & 4.0 & 40 & 40 & 40 & 42 & 42 & 41 & 40 \\
\hline 22 & $28-31$ & Arbutus Lake & Grand Trave & 378 & 2004-09-15 & 14.0 & 4.3 & 39 & 42 & 42 & 45 & 44 & 40 & 40 \\
\hline 22 & $28-31$ & Long Lake & Grand Trave & 2911 & 2004-09-18 & 19.0 & 5.8 & 35 & 40 & 39 & 43 & 41 & 39 & 38 \\
\hline 22 & $28-31$ & Indian Lake & Kalamazoo & 788 & 2004-09-25 & 7.0 & 2.1 & 49 & 53 & 52 & 55 & 53 & 53 & 53 \\
\hline 22 & $28-31$ & Freska Lake & Kent & 59 & 2004-09-23 & 9.5 & 2.9 & 45 & 42 & 42 & 42 & 42 & 41 & 41 \\
\hline
\end{tabular}


Appendix 1. Results and computations by Landsat-satellite path for Michigan inland lakes, 2003-05, of measured and predicted Secchi-disk transparency and Trophic State Index values for the area of interest, area of interest lake-average method, and the Gethist method.-Continued

[SDT, Secchi-disk transparency; AOI, area of interest; TSI, Trophic State Index; Eq, equation; * , measurement not used owing to issue with placement]

\begin{tabular}{|c|c|c|c|c|c|c|c|c|c|c|c|c|c|c|}
\hline \multicolumn{2}{|c|}{ Landsat satellite } & \multirow[b]{2}{*}{ Lake Name } & \multirow[b]{2}{*}{ County } & \multirow[b]{2}{*}{ Acres } & \multicolumn{4}{|c|}{ Measured SDT } & \multicolumn{2}{|c|}{ AOI TSI } & \multicolumn{2}{|c|}{$\begin{array}{c}\text { AOI lake average } \\
\text { TSI }\end{array}$} & \multicolumn{2}{|c|}{ Gethist TSI } \\
\hline Path & Row & & & & Sampled & SDT ft & SDT m & TSI & Eq1 & Eq2 & Eq1 & Eq2 & Eq1 & $\mathrm{Eq} 2$ \\
\hline 22 & $28-31$ & Murray Lake & Kent & 312 & 2004-09-16 & 11.0 & 3.4 & 43 & 46 & 46 & 45 & 44 & 43 & 43 \\
\hline 22 & $28-31$ & Big Star Lake & Lake & 890 & 2004-09-18 & 11.5 & 3.5 & 42 & 38 & 38 & 42 & 41 & 39 & 39 \\
\hline 22 & $28-31$ & Glen Lake Little & Leelanau & 1415 & 2004-09-22 & 7.0 & 2.1 & 49 & 47 & 47 & 46 & 47 & 45 & 47 \\
\hline 22 & 28-31 & Hamlin Lake & Mason & 4622 & 2004-09-19 & 13.5 & 4.1 & 40 & 42 & 41 & 42 & 43 & 41 & 40 \\
\hline 22 & $28-31$ & Hamlin Lake & Mason & 4622 & 2004-09-23 & 9.5 & 2.9 & 45 & 41 & 40 & 43 & 44 & 41 & 40 \\
\hline 22 & $28-31$ & Horsehead Lake & Mecosta & 443 & 2004-09-20 & 15.5 & 4.7 & 38 & 41 & 41 & 46 & 45 & 40 & 41 \\
\hline 22 & 28-31 & Mecosta Lake & Mecosta & 312 & 2004-09-18 & 15.0 & 4.6 & 38 & 41 & 41 & 45 & 45 & 42 & 43 \\
\hline 22 & $28-31$ & Pretty Lake & Mecosta & 116 & 2004-09-19 & 11.0 & 3.4 & 43 & 41 & 42 & 42 & 42 & 40 & 41 \\
\hline 22 & $28-31$ & Round Lake & Mecosta & 157 & 2004-09-18 & 14.0 & 4.3 & 39 & 39 & 38 & 41 & 41 & 40 & 40 \\
\hline 22 & $28-31$ & West Canadian Lake & Mescoda & 133 & 2004-09-17 & 11.5 & 3.5 & 42 & 40 & 40 & 43 & 43 & 42 & 42 \\
\hline 22 & 28-31 & Sapphire Lake & Missaukee & 246 & 2004-09-13 & 7.5 & 2.3 & 48 & 47 & 47 & 48 & 47 & 46 & 46 \\
\hline 22 & $28-31$ & Baldwin Lake & Montcalm & 62 & 2004-09-18 & 9.5 & 2.9 & 45 & 43 & 44 & 44 & 44 & 44 & 44 \\
\hline 22 & $28-31$ & Clifford Lake & Montcalm & 195 & 2004-09-23 & 12.0 & 3.7 & 41 & 43 & 43 & 44 & 44 & 43 & 43 \\
\hline 22 & 28-31 & Bills Lake & Newaygo & 200 & 2004-09-18 & 12.0 & 3.7 & 41 & 40 & 41 & 46 & 46 & 40 & 42 \\
\hline 22 & $28-31$ & Kimball Lake & Newaygo & 147 & 2004-09-19 & 6.0 & 1.8 & 51 & 52 & 52 & 52 & 51 & 52 & 52 \\
\hline 22 & $28-31$ & Pickerel Lake & Newaygo & 308 & 2004-09-19 & 12.0 & 3.7 & 41 & 39 & 39 & 45 & 44 & 42 & 42 \\
\hline 22 & $28-31$ & Sylvan Lake & Newaygo & 102 & 2004-09-16 & 10.0 & 3.0 & 44 & 42 & 43 & 44 & 45 & 40 & 42 \\
\hline 22 & $28-31$ & Crystal Lake & Oceana & 121 & 2004-09-20 & 8.0 & 2.4 & 47 & 44 & 45 & 44 & 44 & 43 & 44 \\
\hline 22 & 28-31 & Robinson Lake & Oceana & 134 & 2004-09-14 & 10.0 & 3.0 & 44 & 41 & 40 & 41 & 40 & 40 & 40 \\
\hline 22 & 28-31 & Stony Lake & Oceana & 287 & 2004-09-15 & 12.0 & 3.7 & 41 & 41 & 41 & 42 & 42 & 41 & 41 \\
\hline 22 & 28-31 & Center Lake & Osceola & 41 & 2004-09-19 & 18.0 & 5.5 & 35 & 40 & 40 & 40 & 39 & 39 & 39 \\
\hline 22 & $28-31$ & Hicks Lake & Osceola & 160 & 2004-09-25 & 3.0 & 0.9 & 61 & 60 & 57 & 60 & 57 & 62 & 58 \\
\hline 22 & 28-31 & Corey Lake & St. Joseph & 599 & 2004-09-24 & 8.5 & 2.6 & 46 & 47 & 48 & 49 & 48 & 44 & 46 \\
\hline
\end{tabular}


Appendix 1. Results and computations by Landsat-satellite path for Michigan inland lakes, 2003-05, of measured and predicted Secchi-disk transparency and Trophic State Index values for the area of interest, area of interest lake-average method, and the Gethist method.-Continued

[SDT, Secchi-disk transparency; AOI, area of interest; TSI, Trophic State Index; Eq, equation; * , measurement not used owing to issue with placement]

\begin{tabular}{|c|c|c|c|c|c|c|c|c|c|c|c|c|c|c|}
\hline \multicolumn{2}{|c|}{ Landsat satellite } & \multirow[b]{2}{*}{ Lake Name } & \multirow[b]{2}{*}{ County } & \multirow[b]{2}{*}{ Acres } & \multicolumn{4}{|c|}{ Measured SDT } & \multicolumn{2}{|c|}{ AOI TSI } & \multicolumn{2}{|c|}{$\begin{array}{c}\text { AOI lake average } \\
\text { TSI }\end{array}$} & \multicolumn{2}{|c|}{ Gethist TSI } \\
\hline Path & Row & & & & Sampled & SDT ft & SDT m & TSI & Eq1 & Eq2 & Eq1 & $\mathrm{Eq} 2$ & Eq1 & $\mathrm{Eq} 2$ \\
\hline 22 & $28-31$ & Fishers Lake & St. Joseph & 330 & 2004-09-25 & 13.5 & 4.1 & 40 & 43 & 43 & 48 & 49 & 42 & 43 \\
\hline 22 & $28-31$ & Fishers Lake & St. Joseph & 330 & 2004-09-18 & 14.0 & 4.3 & 39 & 42 & 43 & 53 & 58 & 42 & 43 \\
\hline 22 & $28-31$ & Pleasant Lake & St. Joseph & 256 & 2004-09-22 & 15.0 & 4.6 & 38 & 41 & 41 & 46 & 44 & 40 & 41 \\
\hline 22 & 28-31 & Wahbememe & St. Joseph & 22 & 2004-09-19 & 16.0 & 4.9 & 37 & * & * & * & * & 42 & 42 \\
\hline 22 & $28-31$ & Cedar Lake & Van Buren & 275 & 2004-09-18 & 13.0 & 4.0 & 40 & 42 & 42 & 45 & 44 & 41 & 41 \\
\hline 22 & $28-31$ & Crooked Lake & Van Buren & 117 & 2004-09-19 & 11.0 & 3.4 & 43 & 39 & 38 & 44 & 44 & 42 & 42 \\
\hline 22 & $28-31$ & Crooked Lake Little & Van Buren & 114 & 2004-09-14 & 14.0 & 4.3 & 39 & 41 & 41 & 43 & 43 & 41 & 41 \\
\hline 22 & $28-31$ & Silver Lake & Van Buren & 50 & 2004-09-19 & 13.5 & 4.1 & 40 & 40 & 39 & 41 & 40 & 40 & 39 \\
\hline 22 & $28-31$ & Stone Ledge Lake & Wexford & 83 & 2004-09-18 & 13.0 & 4.0 & 40 & 43 & 43 & 43 & 43 & 41 & 41 \\
\hline 24 & 27 & Clear Lake & Houghton & 23 & 2005-09-26 & 17.5 & 5.3 & 36 & 38 & 37 & 37 & 36 & 37 & 36 \\
\hline 24 & 27 & Gerald Lake & Houghton & 356 & 2005-09-24 & 13.5 & 4.1 & 40 & 36 & 37 & 41 & 40 & 42 & 42 \\
\hline 24 & 27 & Pike Lake & Houghton & 83 & 2005-09-26 & 8.5 & 2.6 & 46 & 42 & 42 & 42 & 43 & 44 & 44 \\
\hline 24 & 27 & Portage Lake & Houghton & 10808 & 2005-09-24 & 8.5 & 2.6 & 46 & 43 & 41 & 47 & 47 & 47 & 47 \\
\hline 24 & 27 & Roland Lake & Houghton & 258 & 2005-09-24 & 16.0 & 4.9 & 37 & 39 & 39 & 41 & 41 & 41 & 41 \\
\hline 24 & 27 & Torch Lake & Houghton & 2400 & 2005-09-24 & 13.5 & 4.1 & 40 & 33 & 33 & 38 & 38 & 37 & 37 \\
\hline 24 & 27 & Fanny Hooe Lake & Keweenaw & 230 & 2005-09-23 & 14.5 & 4.4 & 39 & 38 & 38 & 39 & 39 & 40 & 40 \\
\hline 24 & 27 & Manganese Lake & Keweenaw & 56 & 2005-09-23 & 12.0 & 3.7 & 41 & 41 & 42 & 41 & 42 & 42 & 42 \\
\hline 24 & 27 & Medora Lake & Keweenaw & 690 & 2005-09-23 & 9.0 & 2.7 & 45 & 42 & 43 & 41 & 41 & 42 & 42 \\
\hline 24 & 27 & Lake Independence & Marquette & 2041 & 2005-09-26 & 6.5 & 2.0 & 50 & 51 & 48 & 50 & 47 & 50 & 49 \\
\hline 24 & 28 & Bass Lake & Dickinson & 60 & 2005-07-21 & 22.0 & 6.7 & 33 & 33 & 33 & 38 & 37 & 33 & 32 \\
\hline 24 & 28 & Carney Lake & Dickinson & 115 & 2005-07-25 & 17.0 & 5.2 & 36 & 39 & 39 & 42 & 41 & 37 & 38 \\
\hline 24 & 28 & Hanbury Lake & Dickinson & 78 & 2005-07-25 & 19.5 & 5.9 & 34 & 38 & 37 & 42 & 40 & 36 & 37 \\
\hline 24 & 28 & Mary Lake & Dickinson & 85 & 2005-07-25 & 15.0 & 4.6 & 38 & 34 & 35 & 53 & 49 & 41 & 41 \\
\hline
\end{tabular}


Appendix 1. Results and computations by Landsat-satellite path for Michigan inland lakes, 2003-05, of measured and predicted Secchi-disk transparency and Trophic State Index values for the area of interest, area of interest lake-average method, and the Gethist method.-Continued

[SDT, Secchi-disk transparency; AOI, area of interest; TSI, Trophic State Index; Eq, equation; *, measurement not used owing to issue with placement]

\begin{tabular}{|c|c|c|c|c|c|c|c|c|c|c|c|c|c|c|}
\hline \multicolumn{2}{|c|}{ Landsat satellite } & \multirow[b]{2}{*}{ Lake Name } & \multirow[b]{2}{*}{ County } & \multirow[b]{2}{*}{ Acres } & \multicolumn{4}{|c|}{ Measured SDT } & \multicolumn{2}{|c|}{ AOI TSI } & \multicolumn{2}{|c|}{$\begin{array}{c}\text { AOI lake average } \\
\text { TSI }\end{array}$} & \multicolumn{2}{|c|}{ Gethist TSI } \\
\hline Path & Row & & & & Sampled & SDT ft & SDT m & TSI & Eq1 & Eq2 & Eq1 & $\mathrm{Eq} 2$ & Eq1 & $\mathrm{Eq} 2$ \\
\hline 24 & 28 & Pickerel Lake & Dickinson & 68 & $2005-07-25$ & 15.5 & 4.7 & 38 & 36 & 36 & 48 & 45 & 40 & 41 \\
\hline 24 & 28 & Bass Lake & Marquette & 76 & $2005-07-25$ & 16.5 & 5.0 & 37 & 37 & 37 & 39 & 39 & 32 & 32 \\
\hline 24 & 28 & Bass Lake & Marquette & 273 & $2005-07-21$ & 8.5 & 2.6 & 46 & 43 & 43 & 51 & 49 & 44 & 44 \\
\hline 24 & 28 & Deer Lake & Marquette & 906 & $2005-07-22$ & 7.0 & 2.1 & 49 & 46 & 45 & 47 & 46 & 45 & 45 \\
\hline 24 & 28 & Engman Lake & Marquette & 48 & $2005-07-21$ & 11.5 & 3.5 & 42 & 44 & 45 & 45 & 46 & 44 & 44 \\
\hline 24 & 28 & Fish Lake & Marquette & 151 & 2005-07-22 & 8.5 & 2.6 & 46 & 36 & 38 & 34 & 36 & 46 & 45 \\
\hline 24 & 28 & Greenwood Reservoir & Marquette & 1073 & 2005-07-22 & 8.5 & 2.6 & 46 & 36 & 38 & 34 & 35 & 45 & 44 \\
\hline 24 & 28 & Horseshoe Lake & Marquette & 126 & $2005-07-22$ & 9.0 & 2.7 & 45 & 40 & 40 & 46 & 44 & 43 & 43 \\
\hline 24 & 28 & Johnson Lake & Marquette & 78 & $2005-07-21$ & 18.0 & 5.5 & 35 & 36 & 35 & 42 & 40 & 35 & 35 \\
\hline 24 & 28 & Little Lake & Marquette & 460 & $2005-07-21$ & 17.0 & 5.2 & 36 & 39 & 38 & 55 & 51 & 42 & 41 \\
\hline 24 & 28 & Squaw Lake & Marquette & 247 & $2005-07-22$ & 18.5 & 5.6 & 35 & 35 & 36 & 39 & 39 & 36 & 34 \\
\hline 25 & 28 & Allen Lake & Gogebic & 78 & $2003-08-28$ & 8.5 & 2.6 & 46 & 45 & 43 & 44 & 42 & 45 & 43 \\
\hline 25 & 28 & Bass Lake & Gogebic & 200 & $2003-08-25$ & 8.5 & 2.6 & 46 & 43 & 43 & 41 & 40 & 46 & 47 \\
\hline 25 & 28 & Beatons Lake & Gogebic & 324 & 2003-08-27 & 18.5 & 5.6 & 35 & 38 & 38 & 41 & 42 & 40 & 39 \\
\hline 25 & 28 & Clark Lake & Gogebic & 836 & $2003-08-26$ & 20.5 & 6.2 & 34 & 39 & 41 & 38 & 42 & 39 & 39 \\
\hline 25 & 28 & Dinner Lake & Gogebic & 108 & 2003-08-12 & 10.5 & 3.2 & 43 & 40 & 43 & 43 & 40 & 39 & 42 \\
\hline 25 & 28 & Duck Lake & Gogebic & 612 & 2003-08-12 & 9.5 & 2.9 & 45 & 42 & 44 & 50 & 50 & 45 & 46 \\
\hline 25 & 28 & Lac Vieux Desert & Gogebic & 4370 & 2003-08-12 & 6.5 & 2.0 & 50 & 49 & 48 & 45 & 45 & 50 & 48 \\
\hline 25 & 28 & Oxbow Lake & Gogebic & 98 & 2003-08-13 & 8.0 & 2.4 & 47 & 42 & 40 & 43 & 43 & 43 & 41 \\
\hline 25 & 28 & Pomeroy Lake & Gogebic & 314 & 2003-08-13 & 6.0 & 1.8 & 51 & 53 & 53 & 49 & 49 & 54 & 54 \\
\hline 25 & 28 & Thousand Island Lake & Gogebic & 1009 & 2003-08-27 & 12.5 & 3.8 & 41 & 43 & 44 & 42 & 42 & 41 & 41 \\
\hline 25 & 28 & Bond Falls Flowage & Ontonagon & 2127 & $2003-08-26$ & 9.0 & 2.7 & 45 & 42 & 42 & 41 & 40 & 42 & 42 \\
\hline 25 & 28 & County Line Lake & Ontonagon & 67 & $2003-08-27$ & 16.0 & 4.9 & 37 & 45 & 43 & 45 & 45 & 39 & 38 \\
\hline
\end{tabular}


Appendix 2. Results and computations by Landsat-satellite path for Michigan inland lakes, 2007-08, of measured and predicted Secchi-disk transparency and Trophic State Index values for the area of interest, area of interest lake-average method, and the Gethist method.

[SDT, Secchi-disk transparency; AOI, area of interest; TSI, Trophic State Index; Eq, equation; * , measurement not used owing to issue with placement]

\begin{tabular}{|c|c|c|c|c|c|c|c|c|c|c|c|c|c|c|}
\hline \multicolumn{2}{|c|}{ Landsat satellite } & \multirow[b]{2}{*}{ Lake Name } & \multirow[b]{2}{*}{ County } & \multirow[b]{2}{*}{ Acres } & \multicolumn{4}{|c|}{ Measured SDT } & \multicolumn{2}{|c|}{ AOI TSI } & \multicolumn{2}{|c|}{ AOI lake } & \multicolumn{2}{|c|}{ Gethist TSI } \\
\hline Path & Row & & & & Sampled & SDT ft & SDT m & TSI & Eq1 & $\mathrm{Eq} 2$ & Eq1 & $\mathrm{Eq} 2$ & Eq1 & $\mathrm{Eq} 2$ \\
\hline 20 & 3031 & Byram Lake & Genesee & 134 & 2007-09-02 & 15.0 & 4.6 & 38 & 39 & 39 & 50 & 48 & 39 & 39 \\
\hline 20 & 3031 & Clear Lake & Jackson & 129 & 2007-08-31 & 12.0 & 3.7 & 41 & 39 & 39 & 53 & 52 & 37 & 38 \\
\hline 20 & 3031 & Vineyard Lake & Jackson & 541 & 2007-08-31 & 12.0 & 3.7 & 41 & 43 & 44 & 49 & 47 & 43 & 42 \\
\hline 20 & 3031 & Base Line Lake & Livingston & 244 & 2007-08-24 & 11.5 & 3.5 & 42 & 40 & 40 & 38 & 38 & 41 & 40 \\
\hline 20 & 3031 & Chemung Lake & Livingston & 313 & $2007-08-27$ & 15.0 & 4.6 & 38 & 38 & 38 & 49 & 47 & 42 & 42 \\
\hline 20 & 3031 & Earl Lake & Livingston & 53 & 2007-08-29 & 6.0 & 1.8 & 51 & 48 & 48 & 43 & 42 & 51 & 51 \\
\hline 20 & 3031 & Gallagher Lake & Livingston & 189 & 2007-09-02 & 10.5 & 3.2 & 43 & 42 & 42 & 41 & 40 & 43 & 42 \\
\hline 20 & 3031 & Green Oak Lake & Livingston & 152 & $2007-08-24$ & 13.5 & 4.1 & 40 & 41 & 41 & 46 & 45 & 39 & 40 \\
\hline 20 & 3031 & Gut Lake & Livingston & 32 & 2007-08-30 & 13.0 & 4.0 & 40 & 41 & 41 & 48 & 48 & 42 & 42 \\
\hline 20 & 3031 & Hamburg Lake & Livingston & 99 & 2007-08-29 & 16.0 & 4.9 & 37 & 41 & 41 & 48 & 47 & 39 & 39 \\
\hline 20 & 3031 & Oneida Lake & Livingston & 46 & 2007-08-25 & 7.0 & 2.1 & 49 & 48 & 48 & 49 & 50 & 45 & 45 \\
\hline 20 & 3031 & Ore Lake & Livingston & 231 & 2007-09-01 & 11.0 & 3.4 & 43 & 42 & 42 & 41 & 39 & 43 & 43 \\
\hline 20 & 3031 & Round Lake & Livingston & 74 & $2007-08-25$ & 7.5 & 2.3 & 48 & 47 & 47 & 42 & 41 & 45 & 46 \\
\hline 20 & 3031 & Strawberry Lake & Livingston & 261 & 2007-09-01 & 8.0 & 2.4 & 47 & 45 & 46 & 46 & 45 & 45 & 45 \\
\hline 20 & 3031 & Buckhorn Lake & Oakland & 43 & 2007-09-02 & 13.0 & 4.0 & 40 & 42 & 42 & 48 & 48 & 41 & 41 \\
\hline 20 & 3031 & Long Lake & Oakland & 104 & 2007-08-30 & 13.0 & 4.0 & 40 & 43 & 43 & 45 & 45 & 42 & 42 \\
\hline 20 & 3031 & Middle Straits Lake & Oakland & 178 & 2007-08-26 & 14.0 & 4.3 & 39 & 37 & 37 & 46 & 46 & 38 & 39 \\
\hline 20 & 3031 & Portage Lake & Washtenaw & 641 & $2007-08-31$ & 10.0 & 3.0 & 44 & 47 & 47 & 46 & 45 & 47 & 47 \\
\hline 21 & 2831 & Cedar Lake & Alcona & 912 & 2007-09-20 & 8.0 & 2.4 & 47 & 48 & 49 & 57 & 54 & 53 & 53 \\
\hline 21 & 2831 & Hubbard Lake & Alcona & 8768 & 2007-09-16 & 12.0 & 3.7 & 41 & 41 & 42 & 44 & 43 & 40 & 41 \\
\hline 21 & 2831 & Vaughn Lake & Alcona & 112 & 2007-09-20 & 15.0 & 4.6 & 38 & 37 & 37 & 41 & 41 & 37 & 38 \\
\hline 21 & 2831 & Osterhout Lake & Allegan & 172 & 2007-09-18 & 10.0 & 3.0 & 44 & 45 & 45 & 48 & 45 & 44 & 43 \\
\hline 21 & 2831 & Bellaire Lake & Antrim & 1789 & 2007-09-20 & 16.0 & 4.9 & 37 & $*$ & $*$ & $*$ & $*$ & 39 & 39 \\
\hline 21 & 2831 & Barlow Lake & Barry & 181 & 2007-09-17 & 10.0 & 3.0 & 44 & 45 & 43 & 47 & 45 & 41 & 41 \\
\hline
\end{tabular}


Appendix 2. Results and computations by Landsat-satellite path for Michigan inland lakes, 2007-08, of measured and predicted Secchi-disk transparency and Trophic State Index values for the area of interest, area of interest lake-average method, and the Gethist method.-Continued

[SDT, Secchi-disk transparency; AOI, area of interest; TSI, Trophic State Index; Eq, equation; *, measurement not used owing to issue with placement]

\begin{tabular}{|c|c|c|c|c|c|c|c|c|c|c|c|c|c|c|}
\hline \multicolumn{2}{|c|}{ Landsat satellite } & \multirow[b]{2}{*}{ Lake Name } & \multirow[b]{2}{*}{ County } & \multirow[b]{2}{*}{ Acres } & \multicolumn{4}{|c|}{ Measured SDT } & \multicolumn{2}{|c|}{ AOI TSI } & \multicolumn{2}{|c|}{ A이 lake } & \multicolumn{2}{|c|}{ Gethist TSI } \\
\hline Path & Row & & & & Sampled & SDT ft & SDT $m$ & TSI & Eq1 & $\mathrm{Eq} 2$ & Eq1 & $\mathrm{Eq} 2$ & Eq1 & $\mathrm{Eq} 2$ \\
\hline 21 & 2831 & Cobb Lake & Barry & 92 & 2007-09-21 & 13.0 & 4.0 & 40 & 42 & 41 & 45 & 44 & 40 & 40 \\
\hline 21 & 2831 & Payne Lake & Barry & 113 & 2007-09-22 & 11.0 & 3.4 & 43 & 41 & 41 & 49 & 46 & 44 & 44 \\
\hline 21 & 2831 & Stuart Lake & Calhoun & 115 & 2007-09-21 & 13.0 & 4.0 & 40 & 45 & 45 & 49 & 46 & 42 & 42 \\
\hline 21 & 2831 & Upper Brace Lake & Calhoun & 71 & 2007-09-21 & 12.0 & 3.7 & 41 & 41 & 41 & 46 & 44 & 42 & 42 \\
\hline 21 & 2831 & Birch Lake & Cass & 282 & 2007-09-20 & 20.0 & 6.1 & 34 & 38 & 38 & 41 & 40 & 39 & 39 \\
\hline 21 & 2831 & Diamond Lake & Cass & 1041 & 2007-09-19 & 13.0 & 4.0 & 40 & 41 & 42 & 42 & 41 & 38 & 39 \\
\hline 21 & 2831 & Eagle Lake & Cass & 400 & 2007-09-19 & 10.5 & 3.2 & 43 & $*$ & $*$ & $*$ & $*$ & 45 & 45 \\
\hline 21 & 2831 & Magician Lake & Cass & 522 & 2007-09-15 & 10.0 & 3.0 & 44 & 44 & 44 & 47 & 44 & 44 & 44 \\
\hline 21 & 2831 & Puterbaugh Lake & Cass & 44 & 2007-09-20 & 9.5 & 2.9 & 45 & 47 & 47 & 50 & 47 & 46 & 46 \\
\hline 21 & 2831 & Twin Lake (north) & Cass & 61 & 2007-09-19 & 10.0 & 3.0 & 44 & $*$ & $*$ & $*$ & * & 43 & 42 \\
\hline 21 & 2831 & Twin Lake (south) & Cass & 43 & 2007-09-19 & 11.5 & 3.5 & 42 & 44 & 44 & 44 & 43 & 43 & 44 \\
\hline 21 & 2831 & Arnold Lake & Clare & 121 & 2007-09-19 & 17.0 & 5.2 & 36 & 36 & 36 & 41 & 39 & 37 & 36 \\
\hline 21 & 2831 & George Lake & Clare & 129 & 2007-09-18 & 11.5 & 3.5 & 42 & 41 & 41 & 43 & 41 & 40 & 40 \\
\hline 21 & 2831 & Lily Lake & Clare & 190 & 2007-09-22 & 11.0 & 3.4 & 43 & 39 & 39 & 41 & 40 & 38 & 38 \\
\hline 21 & 2831 & Shingle Lake & Clare & 30 & 2007-09-18 & 14.0 & 4.3 & 39 & 41 & 41 & 43 & 41 & 40 & 40 \\
\hline 21 & 2831 & Round Lake & Clinton & 87 & 2007-09-16 & 7.5 & 2.3 & 48 & 44 & 44 & 50 & 48 & 45 & 45 \\
\hline 21 & 2831 & Margrethe Lake & Crawford & 1922 & 2007-09-16 & 12.0 & 3.7 & 41 & 37 & 37 & 45 & 43 & 39 & 40 \\
\hline 21 & 2831 & Ponemah Lake & Genesee & 410 & 2007-09-21 & 14.0 & 4.3 & 39 & 40 & 40 & 42 & 41 & 38 & 39 \\
\hline 21 & 2831 & Lake Twenty & Gladwin & 124 & 2007-09-20 & 12.0 & 3.7 & 41 & 43 & 43 & 45 & 43 & 42 & 42 \\
\hline 21 & 2831 & Smallwood Lake & Gladwin & 371 & 2007-09-18 & 9.0 & 2.7 & 45 & 43 & 43 & 51 & 48 & 46 & 46 \\
\hline 21 & 2831 & Lake Diane & Hillsdale & 266 & 2007-09-22 & 2.5 & 0.8 & 64 & 60 & 58 & 68 & 60 & 65 & 62 \\
\hline 21 & 2831 & Rebeck Lake & Hillsdale & 50 & 2007-09-15 & 6.5 & 2.0 & 50 & 46 & 45 & 48 & 46 & 45 & 45 \\
\hline 21 & 2831 & Lansing Lake & Ingham & 456 & 2007-09-20 & 6.0 & 1.8 & 51 & 46 & 46 & 50 & 48 & 46 & 47 \\
\hline 21 & 2831 & Chain Lakes (west) & Iosco & 84 & 2007-09-22 & 12.0 & 3.7 & 41 & 41 & 42 & 55 & 51 & 44 & 45 \\
\hline
\end{tabular}


Appendix 2. Results and computations by Landsat-satellite path for Michigan inland lakes, 2007-08, of measured and predicted Secchi-disk transparency and Trophic State Index values for the area of interest, area of interest lake-average method, and the Gethist method.-Continued

[SDT, Secchi-disk transparency; AOI, area of interest; TSI, Trophic State Index; Eq, equation; * , measurement not used owing to issue with placement]

\begin{tabular}{|c|c|c|c|c|c|c|c|c|c|c|c|c|c|c|}
\hline \multicolumn{2}{|c|}{ Landsat satellite } & \multirow[b]{2}{*}{ Lake Name } & \multirow[b]{2}{*}{ County } & \multirow[b]{2}{*}{ Acres } & \multicolumn{4}{|c|}{ Measured SDT } & \multicolumn{2}{|c|}{ AOI TSI } & \multicolumn{2}{|c|}{ AOI lake } & \multicolumn{2}{|c|}{ Gethist TSI } \\
\hline Path & Row & & & & Sampled & SDT ft & SDT m & TSI & Eq1 & $\mathrm{Eq} 2$ & Eq1 & $\mathrm{Eq} 2$ & Eq1 & $\mathrm{Eq} 2$ \\
\hline 21 & 2831 & Clark Lake & Jackson & 576 & 2007-09-20 & 14.0 & 4.3 & 39 & 44 & 45 & 45 & 45 & 42 & 43 \\
\hline 21 & 2831 & Clear Lake & Jackson & 129 & 2007-09-18 & 11.0 & 3.4 & 43 & 44 & 44 & 47 & 46 & 42 & 43 \\
\hline 21 & 2831 & Vineyard Lake & Jackson & 541 & 2007-09-21 & 13.0 & 4.0 & 40 & 42 & 42 & 52 & 51 & 44 & 45 \\
\hline 21 & 2831 & Wamplers Lake & Jackson & 797 & 2007-09-19 & 7.0 & 2.1 & 49 & 45 & 45 & 50 & 48 & 45 & 45 \\
\hline 21 & 2831 & Sherman Lake & Kalamazoo & 148 & 2007-09-16 & 20.5 & 6.2 & 34 & 39 & 38 & 40 & 38 & 36 & 35 \\
\hline 21 & 2831 & Cub Lake & Kalkaska & 57 & 2007-09-20 & 16.0 & 4.9 & 37 & 41 & 41 & 45 & 44 & 40 & 41 \\
\hline 21 & 2831 & Eagle Lake & Kalkaska & 25 & 2007-09-16 & 16.0 & 4.9 & 37 & 41 & 40 & 42 & 40 & 40 & 40 \\
\hline 21 & 2831 & North Blue Lake & Kalkaska & 56 & 2007-09-22 & 17.0 & 5.2 & 36 & 35 & 34 & 38 & 35 & 36 & 34 \\
\hline 21 & 2831 & Starvation Lake & Kalkaska & 99 & 2007-09-20 & 16.0 & 4.9 & 37 & 41 & 41 & 41 & 38 & 37 & 36 \\
\hline 21 & 2831 & Twin Lake & Kalkaska & 209 & 2007-09-22 & 23.0 & 7.0 & 32 & 46 & 46 & 39 & 36 & 36 & 34 \\
\hline 21 & 2831 & Evans Lake & Lenawee & 215 & 2007-09-19 & 15.0 & 4.6 & 38 & 41 & 41 & 46 & 44 & 41 & 42 \\
\hline 21 & 2831 & Round Lake & Lenawee & 512 & 2007-09-16 & 12.0 & 3.7 & 41 & 46 & 47 & 48 & 47 & 44 & 45 \\
\hline 21 & 2831 & Chemung Lake & Livingston & 313 & 2007-09-17 & 14.0 & 4.3 & 39 & 40 & 40 & 44 & 42 & 40 & 40 \\
\hline 21 & 2831 & Earl Lake & Livingston & 53 & 2007-09-20 & 5.0 & 1.5 & 54 & 54 & 52 & 56 & 53 & 55 & 54 \\
\hline 21 & 2831 & Blue Lake & Mecosta & 229 & 2007-09-18 & 12.0 & 3.7 & 41 & 37 & 37 & 43 & 42 & 40 & 39 \\
\hline 21 & 2831 & Canadian Lakes & Mecosta & 321 & 2007-09-20 & 11.0 & 3.4 & 43 & 41 & 42 & 46 & 43 & 42 & 42 \\
\hline 21 & 2831 & Horsehead Lake & Mecosta & 443 & 2007-09-20 & 10.0 & 3.0 & 44 & 43 & 44 & 47 & 45 & 43 & 44 \\
\hline 21 & 2831 & Mecosta Lake & Mecosta & 312 & 2007-09-22 & 12.0 & 3.7 & 41 & 37 & 37 & 47 & 45 & 41 & 41 \\
\hline 21 & 2831 & Pretty Lake & Mecosta & 116 & 2007-09-22 & 12.0 & 3.7 & 41 & 38 & 38 & 45 & 43 & 41 & 41 \\
\hline 21 & 2831 & Round Lake & Mecosta & 157 & 2007-09-22 & 14.0 & 4.3 & 39 & 42 & 42 & 44 & 42 & 40 & 40 \\
\hline 21 & 2831 & West Canadian Lake & Mescoda & 133 & 2007-09-20 & 12.0 & 3.7 & 41 & 44 & 44 & 44 & 42 & 40 & 40 \\
\hline 21 & 2831 & Baldwin Lake & Montcalm & 62 & 2007-09-18 & 10.0 & 3.0 & 44 & 40 & 41 & 45 & 43 & 41 & 41 \\
\hline 21 & 2831 & Clifford Lake & Montcalm & 195 & 2007-09-22 & 13.0 & 4.0 & 40 & 40 & 40 & 45 & 43 & 42 & 42 \\
\hline 21 & 2831 & East Twin Lake & Montmorency & 820 & 2007-09-22 & 8.5 & 2.6 & 46 & 44 & 45 & 46 & 45 & 42 & 43 \\
\hline
\end{tabular}


Appendix 2. Results and computations by Landsat-satellite path for Michigan inland lakes, 2007-08, of measured and predicted Secchi-disk transparency and Trophic State Index values for the area of interest, area of interest lake-average method, and the Gethist method.-Continued

[SDT, Secchi-disk transparency; AOI, area of interest; TSI, Trophic State Index; Eq, equation; *, measurement not used owing to issue with placement]

\begin{tabular}{|c|c|c|c|c|c|c|c|c|c|c|c|c|c|c|}
\hline \multicolumn{2}{|c|}{ Landsat satellite } & \multirow[b]{2}{*}{ Lake Name } & \multirow[b]{2}{*}{ County } & \multirow[b]{2}{*}{ Acres } & \multicolumn{4}{|c|}{ Measured SDT } & \multicolumn{2}{|c|}{ AOI TSI } & \multicolumn{2}{|c|}{ A이 lake } & \multicolumn{2}{|c|}{ Gethist TSI } \\
\hline Path & Row & & & & Sampled & SDT ft & SDT m & TSI & Eq1 & $\mathrm{Eq} 2$ & Eq1 & $\mathrm{Eq} 2$ & Eq1 & $\mathrm{Eq} 2$ \\
\hline 21 & 2831 & West Twin Lake & Montmorency & 1306 & 2007-09-20 & 8.5 & 2.6 & 46 & 48 & 48 & 50 & 49 & 47 & 48 \\
\hline 21 & 2831 & Bills Lake & Newaygo & 200 & 2007-09-22 & 12.0 & 3.7 & 41 & 36 & 36 & 42 & 41 & 38 & 39 \\
\hline 21 & 2831 & Pickerel Lake & Newaygo & 308 & 2007-09-15 & 12.0 & 3.7 & 41 & 41 & 41 & 43 & 40 & 40 & 39 \\
\hline 21 & 2831 & Center Lake & Osceola & 41 & 2007-09-16 & 20.0 & 6.1 & 34 & 39 & 39 & 42 & 40 & 40 & 39 \\
\hline 21 & 2831 & Hicks Lake & Osceola & 160 & 2007-09-17 & 5.5 & 1.7 & 53 & 52 & 51 & 53 & 50 & 50 & 50 \\
\hline 21 & 2831 & Big Bradford Lake & Otsego & 256 & 2007-09-21 & 22.0 & 6.7 & 33 & 35 & 35 & 42 & 40 & 36 & 36 \\
\hline 21 & 2831 & Big Lake & Otsego & 124 & 2007-09-17 & 19.0 & 5.8 & 35 & 39 & 39 & 41 & 39 & 37 & 37 \\
\hline 21 & 2831 & Crockery Lake & Ottawa & 104 & 2007-09-17 & 7.0 & 2.1 & 49 & 48 & 48 & 50 & 47 & 46 & 47 \\
\hline 21 & 2831 & Corey Lake & St. Joseph & 599 & 2007-09-18 & 14.5 & 4.4 & 39 & 40 & 40 & 43 & 41 & 40 & 39 \\
\hline 21 & 2831 & Fishers Lake & St. Joseph & 330 & 2007-09-22 & 12.0 & 3.7 & 41 & 42 & 43 & 45 & 43 & 43 & 44 \\
\hline 21 & 2831 & Klinger Lake & St. Joseph & 835 & 2007-09-20 & 11.0 & 3.4 & 43 & 45 & 45 & 46 & 45 & 43 & 45 \\
\hline 21 & 2831 & Perrin Lake & St. Joseph & 109 & 2007-09-21 & 10.0 & 3.0 & 44 & 42 & 42 & 51 & 48 & 47 & 46 \\
\hline 21 & 2831 & Cedar Lake & Van Buren & 275 & 2007-09-17 & 13.0 & 4.0 & 40 & 40 & 40 & 44 & 43 & 41 & 40 \\
\hline 21 & 2831 & Crooked Lake & Van Buren & 117 & 2007-09-21 & 10.5 & 3.2 & 43 & 40 & 39 & 43 & 43 & 41 & 40 \\
\hline 21 & 2831 & Crooked Lake Little & Van Buren & 114 & 2007-09-21 & 11.5 & 3.5 & 42 & 41 & 39 & 43 & 43 & 39 & 39 \\
\hline 21 & 2831 & Gravel Lake & Van Buren & 297 & 2007-09-20 & 9.5 & 2.9 & 45 & $*$ & $*$ & $*$ & $*$ & 41 & 40 \\
\hline 21 & 2831 & Maple Lake & Van Buren & 193 & 2007-09-18 & 7.0 & 2.1 & 49 & 45 & 45 & 50 & 47 & 46 & 45 \\
\hline 21 & 2831 & Stone Ledge Lake & Wexford & 83 & 2007-09-18 & 8.5 & 2.6 & 46 & 46 & 47 & 48 & 49 & 45 & 45 \\
\hline 22 & 28 & Frenchman Lake & Chippewa & 185 & 2007-06-26 & 12.0 & 3.7 & 41 & 43 & 43 & 45 & 45 & 43 & 43 \\
\hline 22 & 28 & Trout Lake & Chippewa & 568 & 2007-06-26 & 11.5 & 3.5 & 42 & 41 & 41 & 46 & 45 & 44 & 44 \\
\hline 22 & 28 & Wegwaas Lake & Chippewa & 148 & 2007-06-26 & 10.0 & 3.0 & 44 & 43 & 43 & 44 & 44 & 42 & 43 \\
\hline 22 & 28 & Bass Lake & Luce & 144 & 2007-06-28 & 21.0 & 6.4 & 33 & 36 & 35 & 37 & 36 & 36 & 36 \\
\hline 22 & 28 & Bodi Lake & Luce & 275 & 2007-06-27 & 10.0 & 3.0 & 44 & 48 & 48 & 49 & 48 & 46 & 46 \\
\hline 22 & 28 & Culhane Lake & Luce & 100 & 2007-06-27 & 11.0 & 3.4 & 43 & 45 & 45 & 44 & 44 & 43 & 43 \\
\hline
\end{tabular}


Appendix 2. Results and computations by Landsat-satellite path for Michigan inland lakes, 2007-08, of measured and predicted Secchi-disk transparency and Trophic State Index values for the area of interest, area of interest lake-average method, and the Gethist method.-Continued

[SDT, Secchi-disk transparency; AOI, area of interest; TSI, Trophic State Index; Eq, equation; * , measurement not used owing to issue with placement]

\begin{tabular}{|c|c|c|c|c|c|c|c|c|c|c|c|c|c|c|}
\hline \multicolumn{2}{|c|}{ Landsat satellite } & \multirow[b]{2}{*}{ Lake Name } & \multirow[b]{2}{*}{ County } & \multirow[b]{2}{*}{ Acres } & \multicolumn{4}{|c|}{ Measured SDT } & \multicolumn{2}{|c|}{ AOI TSI } & \multicolumn{2}{|c|}{ A이 lake } & \multicolumn{2}{|c|}{ Gethist TSI } \\
\hline Path & Row & & & & Sampled & SDT ft & SDT m & TSI & Eq1 & $\mathrm{Eq} 2$ & Eq1 & $\mathrm{Eq} 2$ & Eq1 & $\mathrm{Eq} 2$ \\
\hline 22 & 28 & East Lake & Luce & 125 & $2007-06-28$ & 10.0 & 3.0 & 44 & 39 & 40 & 40 & 41 & 39 & 40 \\
\hline 22 & 28 & Kaks Lake & Luce & 59 & $2007-06-28$ & 9.5 & 2.9 & 45 & 43 & 43 & 43 & 43 & 43 & 43 \\
\hline 22 & 28 & Muskallonge Lake & Luce & 762 & 2007-06-27 & 9.0 & 2.7 & 45 & 42 & 43 & 43 & 44 & 42 & 43 \\
\hline 22 & 28 & Perch Lake & Luce & 91 & 2007-06-27 & 19.0 & 5.8 & 35 & 36 & 36 & 37 & 37 & 36 & 35 \\
\hline 22 & 28 & Pike Lake & Luce & 286 & $2007-06-27$ & 9.5 & 2.9 & 45 & 43 & 43 & 42 & 42 & 42 & 41 \\
\hline 22 & 28 & Brevoort Lake & Mackinac & 4315 & 2007-06-26 & 13.0 & 4.0 & 40 & 41 & 42 & 44 & 44 & 42 & 42 \\
\hline 22 & 28 & East Lake & Mackinac & 927 & 2007-06-26 & 10.5 & 3.2 & 43 & 44 & 44 & 46 & 46 & 44 & 45 \\
\hline 22 & 28 & Millecoquins Lake & Mackinac & 1123 & $2007-06-26$ & 8.0 & 2.4 & 47 & 45 & 45 & 50 & 49 & 48 & 47 \\
\hline 22 & 28 & Dutch Fred Lake & Schoolcraft & 34 & 2007-06-28 & 19.0 & 5.8 & 35 & 36 & 36 & 37 & 38 & 36 & 36 \\
\hline 22 & 2931 & Osterhout Lake & Allegan & 172 & 2007-09-14 & 7.0 & 2.1 & 49 & 46 & 45 & 47 & 47 & 45 & 45 \\
\hline 22 & 2931 & Wetmore Lake & Allegan & 46 & 2007-09-20 & 7.5 & 2.3 & 48 & 43 & 45 & 45 & 45 & 43 & 43 \\
\hline 22 & 2931 & Torch Lake & Antrim & 18722 & 2007-09-08 & 21.0 & 6.4 & 33 & 29 & 31 & 32 & 32 & 30 & 31 \\
\hline 22 & 2931 & Woods Lake of the & Antrim & 172 & 2007-09-13 & 5.0 & 1.5 & 54 & 54 & 51 & 55 & 52 & 54 & 52 \\
\hline 22 & 2931 & Barlow Lake & Barry & 181 & 2007-09-15 & 10.5 & 3.2 & 43 & 41 & 42 & 43 & 42 & 44 & 43 \\
\hline 22 & 2931 & Cobb Lake & Barry & 92 & 2007-09-13 & 15.0 & 4.6 & 38 & 42 & 42 & 42 & 40 & 43 & 42 \\
\hline 22 & 2931 & Crooked Lake & Barry & 644 & 2007-09-09 & 7.5 & 2.3 & 48 & 48 & 48 & 49 & 49 & 48 & 47 \\
\hline 22 & 2931 & Payne Lake & Barry & 113 & 2007-09-08 & 7.5 & 2.3 & 48 & 47 & 47 & 49 & 48 & 46 & 46 \\
\hline 22 & 2931 & Ann Lake & Benzie & 501 & 2007-09-08 & 14.5 & 4.4 & 39 & 42 & 43 & 44 & 44 & 42 & 42 \\
\hline 22 & 2931 & Crystal Lake & Benzie & 9869 & 2007-09-08 & 23.0 & 7.0 & 32 & 36 & 38 & 37 & 37 & 36 & 37 \\
\hline 22 & 2931 & Platte Lake & Benzie & 2532 & 2007-09-09 & 11.0 & 3.4 & 43 & 46 & 45 & 47 & 45 & 44 & 44 \\
\hline 22 & 2931 & Sanford Lake & Benzie & 53 & 2007-09-10 & 11.0 & 3.4 & 43 & 42 & 43 & 44 & 45 & 43 & 44 \\
\hline 22 & 2931 & Diamond Lake & Cass & 1041 & 2007-09-11 & 10.0 & 3.0 & 44 & 43 & 39 & 47 & 43 & 43 & 41 \\
\hline 22 & 2931 & Eagle Lake & Cass & 400 & 2007-09-19 & 10.5 & 3.2 & 43 & 46 & 44 & 49 & 47 & 47 & 46 \\
\hline 22 & 2931 & Magician Lake & Cass & 522 & 2007-09-15 & 10.0 & 3.0 & 44 & 44 & 43 & 48 & 46 & 45 & 44 \\
\hline
\end{tabular}


Appendix 2. Results and computations by Landsat-satellite path for Michigan inland lakes, 2007-08, of measured and predicted Secchi-disk transparency and Trophic State Index values for the area of interest, area of interest lake-average method, and the Gethist method.-Continued

[SDT, Secchi-disk transparency; AOI, area of interest; TSI, Trophic State Index; Eq, equation; *, measurement not used owing to issue with placement]

\begin{tabular}{|c|c|c|c|c|c|c|c|c|c|c|c|c|c|c|}
\hline \multicolumn{2}{|c|}{ Landsat satellite } & \multirow[b]{2}{*}{ Lake Name } & \multirow[b]{2}{*}{ County } & \multirow[b]{2}{*}{ Acres } & \multicolumn{4}{|c|}{ Measured SDT } & \multicolumn{2}{|c|}{ AOI TSI } & \multicolumn{2}{|c|}{ A이 lake } & \multicolumn{2}{|c|}{ Gethist TSI } \\
\hline Path & Row & & & & Sampled & SDT ft & SDT $m$ & TSI & Eq1 & $\mathrm{Eq} 2$ & Eq1 & $\mathrm{Eq} 2$ & Eq1 & $\mathrm{Eq} 2$ \\
\hline 22 & 2931 & Puterbaugh Lake & Cass & 44 & 2007-09-12 & 7.0 & 2.1 & 49 & 50 & 47 & 50 & 48 & 48 & 47 \\
\hline 22 & 2931 & Twin Lake (north) & Cass & 61 & 2007-09-14 & 9.5 & 2.9 & 45 & 41 & 40 & 45 & 44 & 41 & 40 \\
\hline 22 & 2931 & Twin Lake (south) & Cass & 43 & 2007-09-08 & 10.5 & 3.2 & 43 & 44 & 41 & 49 & 46 & 44 & 43 \\
\hline 22 & 2931 & George Lake & Clare & 129 & 2007-09-09 & 11.0 & 3.4 & 43 & 46 & 47 & 45 & 46 & 44 & 45 \\
\hline 22 & 2931 & Windover Lake & Clare & 68 & 2007-09-08 & 12.0 & 3.7 & 41 & 47 & 46 & 50 & 48 & 47 & 47 \\
\hline 22 & 2931 & Margrethe Lake & Crawford & 1922 & 2007-09-16 & 12.0 & 3.7 & 41 & 46 & 47 & 49 & 48 & 46 & 47 \\
\hline 22 & 2931 & Bostwick Lake & Kent & 213 & 2007-09-13 & 5.5 & 1.7 & 53 & 48 & 49 & 48 & 48 & 46 & 47 \\
\hline 22 & 2931 & Freska Lake & Kent & 59 & 2007-09-11 & 10.0 & 3.0 & 44 & 43 & 44 & 44 & 45 & 43 & 44 \\
\hline 22 & 2931 & Reeds Lake & Kent & 270 & 2007-09-19 & 4.0 & 1.2 & 57 & 54 & 53 & 55 & 53 & 55 & 54 \\
\hline 22 & 2931 & Big Star Lake & Lake & 890 & 2007-09-11 & 11.0 & 3.4 & 43 & 44 & 46 & 43 & 46 & 43 & 45 \\
\hline 22 & 2931 & Glen Lake & Leelanau & 4871 & 2007-09-12 & 14.5 & 4.4 & 39 & 34 & 34 & 36 & 35 & 34 & 33 \\
\hline 22 & 2931 & Hamlin Lake & Mason & 4622 & 2007-09-14 & 13.0 & 4.0 & 40 & 43 & 46 & 44 & 46 & 43 & 45 \\
\hline 22 & 2931 & Blue Lake & Mecosta & 229 & 2007-09-15 & 11.0 & 3.4 & 43 & 42 & 43 & 46 & 46 & 44 & 45 \\
\hline 22 & 2931 & Canadian Lakes & Mecosta & 321 & 2007-09-20 & 11.0 & 3.4 & 43 & 43 & 45 & 45 & 47 & 45 & 46 \\
\hline 22 & 2931 & Horsehead Lake & Mecosta & 443 & 2007-09-13 & 9.5 & 2.9 & 45 & 46 & 48 & 49 & 48 & 46 & 47 \\
\hline 22 & 2931 & Mecosta Lake & Mecosta & 312 & 2007-09-13 & 10.0 & 3.0 & 44 & 46 & 47 & 49 & 49 & 46 & 47 \\
\hline 22 & 2931 & West Canadian Lake & Mescoda & 133 & 2007-09-20 & 12.0 & 3.7 & 41 & 45 & 47 & 46 & 47 & 45 & 46 \\
\hline 22 & 2931 & Sapphire Lake & Missaukee & 246 & 2007-09-10 & 7.5 & 2.3 & 48 & 46 & 47 & 48 & 48 & 47 & 48 \\
\hline 22 & 2931 & Baldwin Lake & Montcalm & 62 & 2007-09-13 & 9.0 & 2.7 & 45 & 44 & 45 & 45 & 46 & 44 & 44 \\
\hline 22 & 2931 & Clifford Lake & Montcalm & 195 & 2007-09-15 & 9.0 & 2.7 & 45 & 45 & 46 & 46 & 47 & 44 & 46 \\
\hline 22 & 2931 & Bills Lake & Newaygo & 200 & 2007-09-14 & 10.5 & 3.2 & 43 & 43 & 42 & 46 & 44 & 43 & 42 \\
\hline 22 & 2931 & Emerald Lake & Newaygo & 77 & 2007-09-13 & 11.5 & 3.5 & 42 & 44 & 44 & 45 & 44 & 44 & 44 \\
\hline 22 & 2931 & Fremont Lake & Newaygo & 825 & 2007-09-12 & 8.0 & 2.4 & 47 & 51 & 50 & 51 & 49 & 49 & 48 \\
\hline 22 & 2931 & Hess Lake & Newaygo & 765 & 2007-09-11 & 2.5 & 0.8 & 64 & 62 & 57 & 62 & 58 & 64 & 60 \\
\hline
\end{tabular}


Appendix 2. Results and computations by Landsat-satellite path for Michigan inland lakes, 2007-08, of measured and predicted Secchi-disk transparency and Trophic State Index values for the area of interest, area of interest lake-average method, and the Gethist method.-Continued

[SDT, Secchi-disk transparency; AOI, area of interest; TSI, Trophic State Index; Eq, equation; * , measurement not used owing to issue with placement]

\begin{tabular}{|c|c|c|c|c|c|c|c|c|c|c|c|c|c|c|}
\hline \multicolumn{2}{|c|}{ Landsat satellite } & \multirow[b]{2}{*}{ Lake Name } & \multirow[b]{2}{*}{ County } & \multirow[b]{2}{*}{ Acres } & \multicolumn{4}{|c|}{ Measured SDT } & \multicolumn{2}{|c|}{ AOI TSI } & \multicolumn{2}{|c|}{ A이 lake } & \multicolumn{2}{|c|}{ Gethist TSI } \\
\hline Path & Row & & & & Sampled & SDT ft & SDT m & TSI & Eq1 & $\mathrm{Eq} 2$ & Eq1 & Eq2 & Eq1 & $\mathrm{Eq} 2$ \\
\hline 22 & 2931 & Kimball Lake & Newaygo & 147 & 2007-09-15 & 6.5 & 2.0 & 50 & 48 & 48 & 47 & 48 & 47 & 48 \\
\hline 22 & 2931 & Pickerel Lake & Newaygo & 308 & 2007-09-15 & 12.0 & 3.7 & 41 & 44 & 45 & 46 & 46 & 44 & 45 \\
\hline 22 & 2931 & Sylvan Lake & Newaygo & 102 & 2007-09-13 & 11.0 & 3.4 & 43 & 43 & 42 & 45 & 43 & 43 & 42 \\
\hline 22 & 2931 & Robinson Lake & Oceana & 134 & 2007-09-16 & 9.5 & 2.9 & 45 & 45 & 47 & 46 & 47 & 45 & 47 \\
\hline 22 & 2931 & Stony Lake & Oceana & 287 & 2007-09-14 & 8.0 & 2.4 & 47 & 42 & 43 & 43 & 44 & 43 & 44 \\
\hline 22 & 2931 & Hicks Lake & Osceola & 160 & 2007-09-09 & 5.5 & 1.7 & 53 & 50 & 51 & 50 & 50 & 50 & 51 \\
\hline 22 & 2931 & Viking Lake & Otsego & 36 & 2007-09-20 & 4.0 & 1.2 & 57 & 51 & 49 & 51 & 50 & 50 & 50 \\
\hline 22 & 2931 & Crockery Lake & Ottawa & 104 & 2007-09-11 & 7.0 & 2.1 & 49 & 46 & 45 & 48 & 47 & 47 & 47 \\
\hline 22 & 2931 & Corey Lake & St. Joseph & 599 & 2007-09-11 & 14.5 & 4.4 & 39 & 43 & 42 & 45 & 43 & 42 & 40 \\
\hline 22 & 2931 & Cedar Lake & Van Buren & 275 & 2007-09-15 & 16.5 & 5.0 & 37 & 40 & 40 & 44 & 42 & 41 & 40 \\
\hline 22 & 2931 & Crooked Lake & Van Buren & 117 & 2007-09-09 & 11.0 & 3.4 & 43 & 41 & 40 & 45 & 42 & 41 & 40 \\
\hline 22 & 2931 & Crooked Lake Little & Van Buren & 114 & 2007-09-12 & 13.0 & 4.0 & 40 & 37 & 37 & 43 & 41 & 42 & 40 \\
\hline 22 & 2931 & Gravel Lake & Van Buren & 297 & 2007-09-13 & 9.0 & 2.7 & 45 & 43 & 43 & 44 & 43 & 41 & 40 \\
\hline 22 & 2931 & School Section Lake & Van Buren & 79 & 2007-09-13 & 9.0 & 2.7 & 45 & 48 & 47 & 48 & 47 & 47 & 47 \\
\hline 22 & 2931 & Silver Lake & Van Buren & 50 & 2007-09-13 & 10.0 & 3.0 & 44 & 41 & 41 & 42 & 43 & 41 & 41 \\
\hline 22 & 2931 & Pleasant Lake & Wexford & 130 & 2007-09-13 & 8.5 & 2.6 & 46 & 46 & 48 & 46 & 48 & 45 & 47 \\
\hline 22 & 2931 & Stone Ledge Lake & Wexford & 83 & 2007-09-14 & 9.0 & 2.7 & 45 & 45 & 45 & 48 & 46 & 48 & 49 \\
\hline 23 & 28 & Deer Lake & Alger & 266 & 2007-08-07 & 11.0 & 3.4 & 43 & 44 & 44 & 41 & 41 & 42 & 42 \\
\hline 23 & 28 & Fish Lake & Alger & 134 & 2007-08-07 & 14.5 & 4.4 & 39 & 38 & 37 & 41 & 41 & 42 & 42 \\
\hline 23 & 28 & Dana Lake & Delta & 85 & 2007-08-07 & 9.5 & 2.9 & 45 & 45 & 45 & 43 & 43 & 43 & 43 \\
\hline 23 & 28 & Deep Lake & Delta & 39 & 2007-08-07 & 14.5 & 4.4 & 39 & 40 & 40 & 41 & 40 & 40 & 40 \\
\hline 23 & 28 & Round Lake & Delta & 482 & 2007-08-07 & 15.5 & 4.7 & 38 & 39 & 39 & 42 & 41 & 41 & 41 \\
\hline 23 & 28 & Bass Lake & Marquette & 76 & 2007-08-06 & 20.0 & 6.1 & 34 & 37 & 37 & 36 & 36 & 35 & 35 \\
\hline 23 & 28 & Engman Lake & Marquette & 48 & $2007-08-06$ & 10.0 & 3.0 & 44 & 41 & 41 & 42 & 41 & 41 & 41 \\
\hline
\end{tabular}


Appendix 2. Results and computations by Landsat-satellite path for Michigan inland lakes, 2007-08, of measured and predicted Secchi-disk transparency and Trophic State Index values for the area of interest, area of interest lake-average method, and the Gethist method.-Continued

[SDT, Secchi-disk transparency; AOI, area of interest; TSI, Trophic State Index; Eq, equation; *, measurement not used owing to issue with placement]

\begin{tabular}{|c|c|c|c|c|c|c|c|c|c|c|c|c|c|c|}
\hline \multicolumn{2}{|c|}{ Landsat satellite } & \multirow[b]{2}{*}{ Lake Name } & \multirow[b]{2}{*}{ County } & \multirow[b]{2}{*}{ Acres } & \multicolumn{4}{|c|}{ Measured SDT } & \multicolumn{2}{|c|}{ AOI TSI } & \multicolumn{2}{|c|}{ A이 lake } & \multicolumn{2}{|c|}{ Gethist TSI } \\
\hline Path & Row & & & & Sampled & SDT ft & SDT m & TSI & Eq1 & $\mathrm{Eq} 2$ & Eq1 & $\mathrm{Eq} 2$ & Eq1 & $\mathrm{Eq} 2$ \\
\hline 23 & 28 & Johnson Lake & Marquette & 78 & 2007-08-06 & 18.0 & 5.5 & 35 & 36 & 36 & 38 & 37 & 36 & 36 \\
\hline 23 & 28 & Little Shag Lake & Marquette & 107 & 2007-08-06 & 14.0 & 4.3 & 39 & 37 & 37 & 38 & 38 & 38 & 38 \\
\hline 23 & 28 & Pike Lake & Marquette & 90 & 2007-08-06 & 14.0 & 4.3 & 39 & 39 & 40 & 41 & 40 & 39 & 39 \\
\hline 23 & 28 & Shag Lake & Marquette & 195 & 2007-08-06 & 13.5 & 4.1 & 40 & 39 & 39 & 41 & 40 & 40 & 40 \\
\hline 23 & 28 & Sporley Lake & Marquette & 77 & 2007-08-06 & 14.0 & 4.3 & 39 & 38 & 38 & 39 & 38 & 38 & 38 \\
\hline 23 & 28 & Grassy Lake & Schoolcraft & 188 & 2007-08-08 & 11.0 & 3.4 & 43 & 41 & 42 & 43 & 42 & 42 & 41 \\
\hline 23 & 28 & McKeever Lake & Schoolcraft & 147 & 2007-08-08 & 13.0 & 4.0 & 40 & 40 & 39 & 42 & 41 & 41 & 41 \\
\hline 23 & 28 & Petes Lake & Schoolcraft & 194 & 2007-08-08 & 17.0 & 5.2 & 36 & 37 & 37 & 36 & 36 & 35 & 35 \\
\hline 24 & 2728 & Bass Lake & Dickinson & 60 & 2008-07-31 & 16.4 & 5.0 & 37 & 38 & 38 & 38 & 38 & 36 & 37 \\
\hline 24 & 2728 & Carney Lake & Dickinson & 115 & 2008-07-31 & 11.1 & 3.4 & 42 & 39 & 39 & 39 & 39 & 39 & 39 \\
\hline 24 & 2728 & Hanbury Lake & Dickinson & 78 & 2008-07-31 & 18.3 & 5.6 & 35 & $*$ & $*$ & $*$ & $*$ & 38 & 37 \\
\hline 24 & 2728 & Mary Lake & Dickinson & 85 & 2008-07-31 & 14.8 & 4.5 & 38 & 40 & 39 & 40 & 38 & 39 & 38 \\
\hline 24 & 2728 & Gerald Lake & Houghton & 356 & 2008-07-29 & 11.8 & 3.6 & 42 & 45 & 44 & 46 & 45 & 46 & 45 \\
\hline 24 & 2728 & Otter Lake & Houghton & 863 & 2008-07-30 & 11.5 & 3.5 & 42 & 44 & 45 & 45 & 45 & 44 & 45 \\
\hline 24 & 2728 & Pike Lake & Houghton & 83 & 2008-07-29 & 7.9 & 2.4 & 47 & 48 & 48 & 46 & 45 & 45 & 45 \\
\hline 24 & 2728 & Roland Lake & Houghton & 258 & 2008-07-29 & 11.3 & 3.4 & 42 & 44 & 44 & 45 & 45 & 46 & 45 \\
\hline 24 & 2728 & Sandy Lake & Houghton & 101 & 2008-07-29 & 7.0 & 2.1 & 49 & 47 & 47 & 46 & 45 & 47 & 45 \\
\hline 24 & 2728 & Torch Lake & Houghton & 2400 & 2008-07-30 & 10.0 & 3.0 & 44 & 43 & 43 & 45 & 45 & 44 & 45 \\
\hline 24 & 2728 & La Belle Lac & Keweenaw & 1205 & 2008-07-30 & 8.0 & 2.4 & 47 & 46 & 46 & 46 & 46 & 45 & 45 \\
\hline 24 & 2728 & Manganese Lake & Keweenaw & 56 & 2008-07-30 & 9.5 & 2.9 & 45 & 44 & 43 & 46 & 45 & 45 & 45 \\
\hline 24 & 2728 & Medora Lake & Keweenaw & 690 & 2008-07-30 & 9.0 & 2.7 & 45 & 45 & 45 & 45 & 45 & 44 & 45 \\
\hline 24 & 2728 & Engman Lake & Marquette & 48 & 2008-07-30 & 10.0 & 3.0 & 44 & 45 & 45 & 45 & 45 & 43 & 45 \\
\hline 24 & 2728 & Fish Lake & Marquette & 151 & 2008-07-28 & 7.9 & 2.4 & 47 & 47 & 47 & 47 & 47 & 47 & 47 \\
\hline 24 & 2728 & Greenwood Reservoir & Marquette & 1073 & $2008-07-28$ & 6.8 & 2.1 & 49 & 46 & 46 & 46 & 46 & 46 & 46 \\
\hline
\end{tabular}


Appendix 2. Results and computations by Landsat-satellite path for Michigan inland lakes, 2007-08, of measured and predicted Secchi-disk transparency and Trophic State Index values for the area of interest, area of interest lake-average method, and the Gethist method.-Continued

[SDT, Secchi-disk transparency; AOI, area of interest; TSI, Trophic State Index; Eq, equation; *, measurement not used owing to issue with placement]

\begin{tabular}{|c|c|c|c|c|c|c|c|c|c|c|c|c|c|c|}
\hline \multicolumn{2}{|c|}{ Landsat satellite } & \multirow[b]{2}{*}{ Lake Name } & \multirow[b]{2}{*}{ County } & \multirow[b]{2}{*}{ Acres } & \multicolumn{4}{|c|}{ Measured SDT } & \multicolumn{2}{|c|}{ AOI TSI } & \multicolumn{2}{|c|}{ AOI lake } & \multicolumn{2}{|c|}{ Gethist TSI } \\
\hline Path & Row & & & & Sampled & SDT ft & SDT $\mathrm{m}$ & TSI & Eq1 & $\mathrm{Eq} 2$ & Eq1 & Eq2 & Eq1 & Eq2 \\
\hline 24 & 2728 & Lake Independence & Marquette & 2041 & $2008-07-28$ & 10.5 & 3.2 & 43 & 44 & 44 & 45 & 45 & 45 & 45 \\
\hline 24 & 2728 & Lake Michigamme & Marquette & 4292 & 2008-07-29 & 8.8 & 2.7 & 46 & 46 & 46 & 46 & 46 & 46 & 46 \\
\hline 25 & 28 & Allen Lake & Gogebic & 78 & 2008-08-06 & 14.5 & 4.4 & 39 & 35 & 39 & 33 & 47 & 39 & 41 \\
\hline 25 & 28 & Beatons Lake & Gogebic & 324 & 2008-08-05 & 22.0 & 6.7 & 33 & 33 & 34 & 32 & 35 & 31 & 30 \\
\hline 25 & 28 & Cisco Lake & Gogebic & 567 & 2008-08-05 & 5.5 & 1.7 & 53 & 49 & 47 & 44 & 50 & 50 & 47 \\
\hline 25 & 28 & Duck Lake & Gogebic & 612 & 2008-08-06 & 11.5 & 3.5 & 42 & 44 & 46 & 38 & 48 & 43 & 44 \\
\hline 25 & 28 & Imp Lake & Gogebic & 91 & $2008-08-06$ & 24.0 & 7.3 & 31 & 28 & 28 & 33 & 39 & 33 & 33 \\
\hline 25 & 28 & Lac Vieux Desert & Gogebic & 4370 & $2008-08-06$ & 7.5 & 2.3 & 48 & 47 & 42 & 42 & 50 & 48 & 46 \\
\hline 25 & 28 & Little Duck Lake & Gogebic & 44 & 2008-08-06 & 19.0 & 5.8 & 35 & 39 & 40 & 35 & 45 & 35 & 38 \\
\hline 25 & 28 & Marion Lake & Gogebic & 297 & 2008-08-06 & 12.0 & 3.7 & 41 & 41 & 39 & 32 & 42 & 37 & 37 \\
\hline 25 & 28 & Thousand Island Lake & Gogebic & 1009 & $2008-08-06$ & 12.5 & 3.8 & 41 & 39 & 40 & 38 & 43 & 37 & 38 \\
\hline 25 & 28 & Golden Lake & Iron & 274 & 2008-08-04 & 22.0 & 6.7 & 33 & 33 & 33 & 38 & 40 & 33 & 34 \\
\hline 25 & 28 & Hagerman Lake & Iron & 565 & 2008-08-04 & 17.0 & 5.2 & 36 & 38 & 40 & 42 & 47 & 42 & 41 \\
\hline 25 & 28 & Ottawa Lake & Iron & 532 & 2008-08-04 & 20.5 & 6.2 & 34 & 39 & 40 & 41 & 44 & 38 & 38 \\
\hline 25 & 28 & Smoky Lake & Iron & 596 & 2008-08-04 & 14.5 & 4.4 & 39 & 41 & 37 & 41 & 41 & 37 & 35 \\
\hline 25 & 28 & Lake Gogebic & Ontonagon & 13127 & 2008-08-05 & 8.0 & 2.4 & 47 & 43 & 46 & 50 & 51 & 46 & 48 \\
\hline
\end{tabular}



